\title{
DESENVOLVIMENTO DO FEIJOEIRO (Dhaseolus oulgaris L.) SUBMETIDO A DIFERENTES LÂMINAS MÉDIAS DE ÁGUA ATRAVÉS DA IRRIGAÇÃO POR SULCO
}

\author{
MARCOS VINÍCIUS FOLEGATTI
}

Orientador: Prof. Dr. ANTONIO SANCHEZ DE OLIVEIRA

Dissertação apresentada à Escola

Superior de Agricultura "Luiz de

Queiroz", da Universidade de São

Paulo, para obtenção do título de

Mestre em Irrigação $\theta$ Drenagem.

PIRACICABA

Estado de São Paulo - Brasil:

Fevereiro - 1985. 
A meus pais

Francisco e Dirce

e a minha sogra Luiza

DEDICO.

A minha esposa Elisabete

e à meu filho Lucas, OFEREÇO. 
AGRADEC IMENTOS

A Deus, pela fé e perseverança concedidas em todos os momentos.

Ao Prof. Dr. Antonio Sanchez de 0liveira pela orientação, amizade e apoio recebidos no decorrer do curso e na realização deste trabalho.

Ao Prof. Dr. Rubens Scardua pelas valiosas sugestões e orientação.

Ao Prof. Ass. Tarlei Arriel Botrel pelo apoio e efetiva participação em todos os passos deste trabalho.

Ao Prof. Dr. Antonio Fernando Lordelo 01itta pelas sugestões.

Ao Prof. Dr. Valdemar Antonio Demétrio pelo apoio e incentivo.

Aos Profs. Drs. Clarice Garcia Borges Demétrio e Decio Barbin pelo valioso auxílio na análise estatística.

Ao Prof. Dr. Rubens Angulo Filho pela colabora ção nos desenhos.

Ao Prof. Dr: Decio Eugenio Cruciani pela colaboração prestada na elaboração do summary. 
Ao Prof. Dr. Antonio Petta Chefe do Departamen to de. Engenharia Rural pelo apoio concedido.

Ao Prof. Dr. Octavio Nakano pelo auxílio no controle das pragas.

Ao Prof. Dr. Ricardo. Victória Filho pelo auxílio no controle das ervas daninhas.

Ao Prof. Dr. Homero Bergamaschi da Universidade Federal do Rio Grande do Sul pela orientação na análise de crescimento da cultura.

Aos Estagiários Celso Luiz Rodrigues Vegro e Maria Raquel Pinto pela inestimāvel colaboração neste trabalho: Ao Sr. Laudelino Polizel, funcionário do Depar tamento de Engenharia Rural da ESALQ, pelo interesse e dedicação .

A Empresa Brasileira de Pesquisa AgropecuäriaEMBRAPA, pela concessão da bólsa de estudos para a realização do Curso de Mestrado em Irrigação e Drenagem.

Ao Instituto Agronômico de Campinas em nome do pesquisador Dr. Eduardo Bulisani pela doação das sementes.

A Indústria e Comércio de Fertilizantes, Agrofértil S/A, em nome do Eng: Agr : Rubens Francisco Teixeira pe1a doação do fertilizante nitrogenado. 
Aos demais professores, colegas de curso e funcionários do Departamento de Engenharia Rural pelas sugestōes e convívio amigo. 


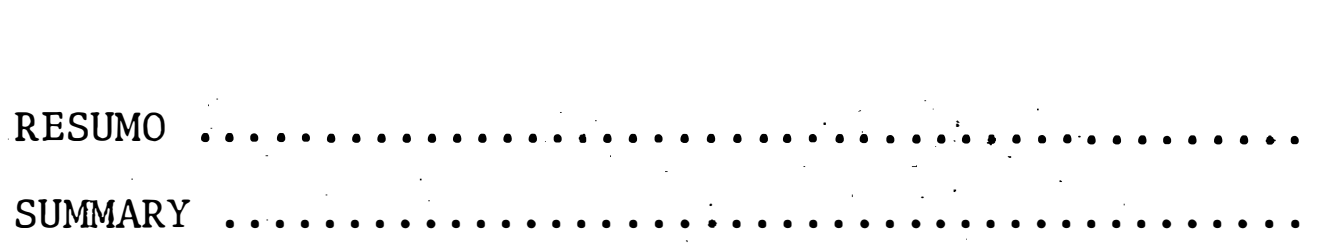

Página

$x v i$

xviii

1. INTRODUC,AO $\ldots \ldots \ldots \ldots \ldots \ldots \ldots \ldots \ldots \ldots \ldots \ldots \ldots \ldots \ldots \ldots \ldots \ldots$

2. REVISÃO DA LITERATURA $\ldots \ldots \ldots \ldots \ldots \ldots \ldots \ldots \ldots \ldots \ldots \ldots \ldots \ldots \ldots \ldots$

2.1. Avaliação da Irrigação ................ 3 :

2.2.Efeito da Irrigação na Cultura do Feijoeiro ... 8

2.3. Distribuição do Sistema Radicular do Feijoeiro 16

3. MATERIAis E MEtOdos ...................... 17

3.1. Local, Clima e Solo ................. 17

3.2. Determinação dos Parâmetros do Solo ......... 18

3.2.1. Granulometria e Densidade ........... 18

3.2.2. Curva de Retenção e Água Disponíve1 ... : 19

3.2.3. Curvas e Equações de Avanço e de Infil-

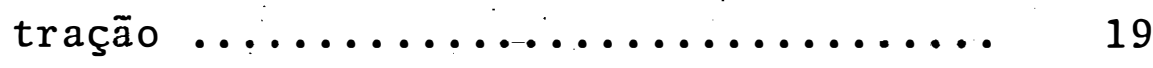

3.3. Instalação do Experimento ............. 22

3.3.1. Sistematização do Terreno para Irri-

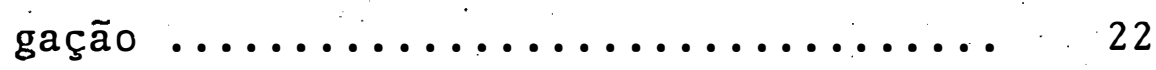

3.3.2. Dados Meteorológicos ............ 23

3.3.3. Suprimento de Água ............... 23

3.3.4. Manejo da Irrigação ............ 24

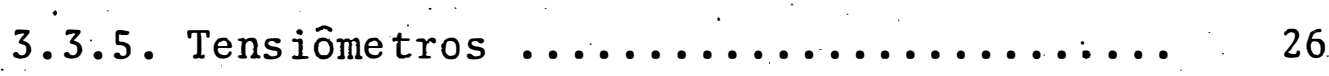

3.4. Delineamen to Experimental ............ 27

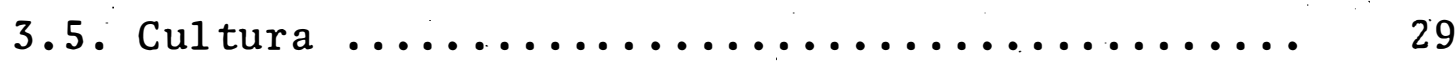

3.5.1. Plantio e Tratos Culturais ......... 29 
Pägina

3.5.2. Fenologia .................. 31

3.5.3. Anâlise dos Parâmetros de Crescimento. 31

3.6. Anālise Estatística ................ 32

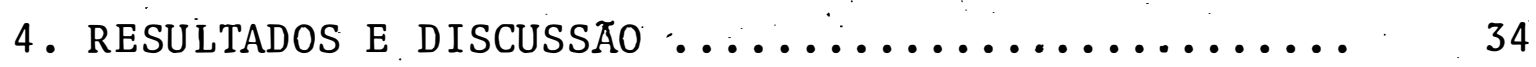

4.1. Curva de Avanço .................. 34

4.2. Curva de Infiltração............... 37

4.3. Avaliação da Irrigação .............. 37

4.4. Manejo da Irrigação ................ 48

4.5. Análise de Crescimento .................... 60

4.6. Parâmetros de Rendimento ................. 64

4.6.1. Produtividade de Grãos .............. 64

4.6.2. Número de Vagens por Planta ....... 66

4.6.3. Nǘmero de Grãos por Vagem ......... 70

4.6.4. Número de Nós por Planta .......... 73

4.6.5. Número de Ramificações por Planta .... 74 .

4.6.6. Comprimento do Caule ........... 76

4.6.7. Matéria Seca Total da Parte Aẹrea em Gramas por 10 Plantas ............ 80

4.7. Acréscimo de Produção Devido a Irrigação. Anāl ise Econômica ................... 83

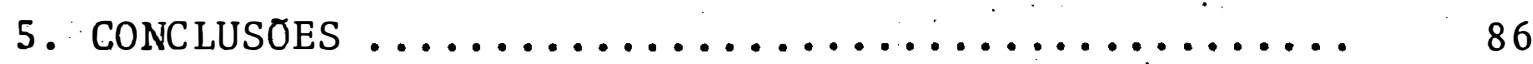

6. Literatura CITADA $\ldots \ldots \ldots \ldots \ldots \ldots \ldots \ldots \ldots \ldots \ldots \ldots$ 
LISTA DE TABELAS

Página

TABELA 1 - Granulometria, Classe Textural e Peso Especí fico Aparente $\ldots \ldots \ldots \ldots \ldots \ldots \ldots \ldots \ldots \ldots$

TABELA 2 - Valores Médios dos Tempos de Avanço da Agua no Sulco de $120 \mathrm{~m}$ para as Vazões de 1,0 e

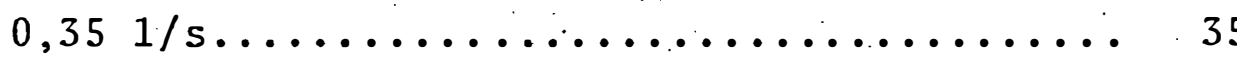

TABELA 3 - Dados Mêdios da Velocidade de Infiltração da Água no Solo para Vazão de $1,0.1 / s \ldots \ldots \ldots$.

TABELA 4- - Dados Médios da Velocidade de Infiltração da Agua no Solo para. Vazão de $0,501 /$ s....... 40

TAB̊ElA 5 - Dados Médios da Velocidade de Infiltração da Agua no Solo para Vazão de $0,351 / s \ldots . . .441$

TABELA 6 - Valores da Lâmina de Irrigação para cada Estaca ao Longo do Sulco para os"Tratamentos I, I I e III. . . . . . . . . . . . . . . . .

TABELA 7 - Eficiências de Armazenamento (Ear), de Ap1icação (Ea) e de Distribuição (Ed) e Perdas por Percolação (Pp) e por Runoff $(\operatorname{Pr}) \ldots . .$.

TABELA 8 - Valores Referentes à Produtividade Média de Grãos em kg/ha, para os Diferentes Tratamentos no Início, Meio e Final de Sulco....... 
TABELA 9 - Anâlise Estatística em Blocos Casualizados com Sub-Parcelas em Classificação Hierārquica para Produtividade de Grãos sob Difé rentes Tratamentos de Irrigação por Sulco.

TABELA 10- Número Mêdio de Vagens por Planta obtido no Início, Meio e Final do Sulco para Dife

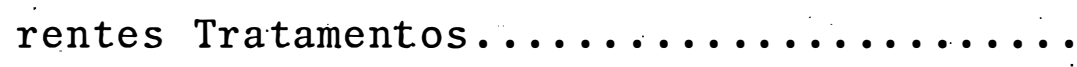

TABELA 11-Anālise Estatística em Blocos Casualizados com Sub-Parcelas em Classificação Hierärquica para Número de Vagens por Planta sob Diferentes Tratamentos de Irrigação. por

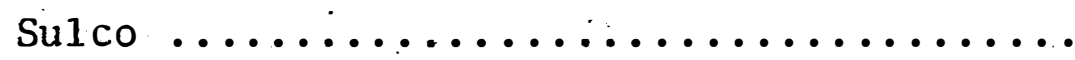

TABELA 12- Número Médio de Grãos por Vagem obtidos no Início, Meio e Final do Sulco nos Diferen-

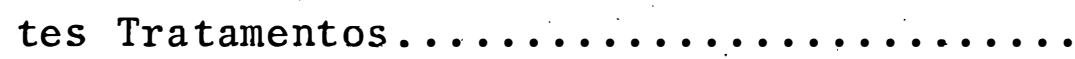

TABELA 13- Anālise Estatística em Blocos Casualizados com Sub-Parcelas em Classificação Hierārquica para Nủmero de Grãos por Vagem sob Diferentes Tratamentos de Irrigação por

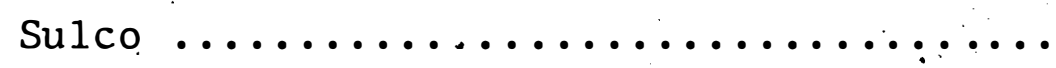

TABELA 14- Número Médio de Nôs por Planta obtido no Início, Meio e Final do Sulco, nos Dife-

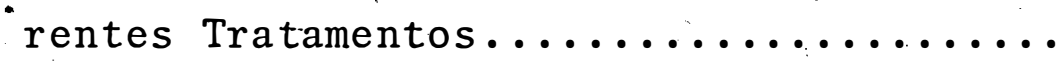


TABELA 15 - Anảlise Estatística em Blocios Casualizados com Sub-Parcelas em C1assificação Hierārquica para Número de Nós por Pilanta sob Diferentes Tratamentos de Irrigação por $\operatorname{sulco\ldots \ldots \ldots \ldots \ldots \ldots \ldots \ldots \ldots \ldots \ldots \ldots \ldots \ldots \ldots \ldots \ldots \ldots \ldots \ldots }$

TABELA 16 - Número Médio de Ramificações por Planta ob tido no Início, Meio e Final do Sulco nos

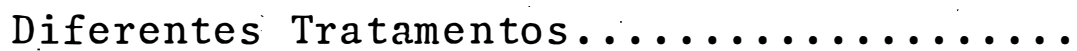

TABELA 17 - Anáiise Estatística em Blocos Cásualizados com Sub-Parcelas em Classificação Hierārquica para Número de Ramificações. por Planta sob Diferentes Tratamentos de Irri-

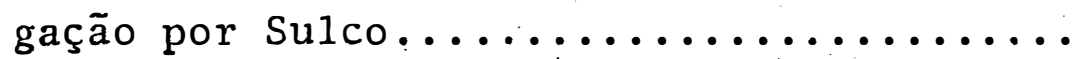

TABELA 18 - Comprimento Médio de Caule (cm) obtido no Início, Meio e Final do Sulco nos Diferentes $\operatorname{Tratamentos} \ldots \ldots \ldots \ldots \ldots \ldots \ldots \ldots \ldots \ldots$

TABELA 19 - Anảlise Estatística em Blocos Casualizados com Sub-Parcelas em Classificaçã̃o Hierārquica para Comprimento de Caule sob Diferentes Tratamentoṣ de Irrigação por Sulco

TABELA 20 - Matéria Seca Total da Parte Aérea em Gramas por 10 Plantas obtida no Início, Meio e Final de Sulco nos Diferentes Tratamentos $\ldots \ldots \ldots \ldots \ldots \ldots \ldots \ldots \ldots$ 
TABELA 21 - Anâlise Estatística em Blocos Casualizados çom Sub-Parcelas em Classificação Hierārquica para Matéria Seca Total da Parte Aérea por 10 Plantas sob Diferentes Tratamen tos de Irrigação por Sulco............

TABELA 22 - Cusțo da Produção do Feijão sem Considerar o da Irrigação...................

TABELA 23 - Anālise da Relação Benefício/Custo....... 
Pägina

FIGURA 1 - Curva Característica da Agua no Solo...... 20

FIGURA 2 - Terreno Sistematizado para Irrigação, com Sulcos de 0,6\% de Declividade, Espaçados de $1,00 \mathrm{~m}$ e Interceptados pelo Conjunto de Calhas $\ldots \ldots \ldots \ldots \ldots \ldots \ldots \ldots \ldots \ldots$

FIGURA 3 - Conjunto de Calhas de Chapa de Aço Galvani zado Distribuidas de Maneira Escalonada, à Guisa de Canal Adutor................ 26

FIGURA 4 - Tensiômetros, Conjunto de Calhas, Sifões e Sulcos em Funcionamento ná Cultura do Feijoeiro 45 dias após Emergência......... 26

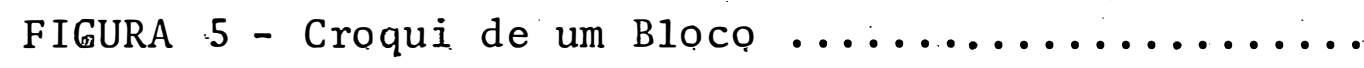

FIgURA 6 - Curvas do Avanço da Agua no Sulco para as Vazões de $1,01 / \mathrm{s}$ e $0,351 / \mathrm{s} \ldots \ldots \ldots \ldots \ldots$

FIGURA 7-Curvas de Velocidade de Infiltração para as Väzões de $1,0,0,5$ e $0,351 /$ s.............

FIGURA 8 - Curvas de Infiltrações Instantânea e Acumu

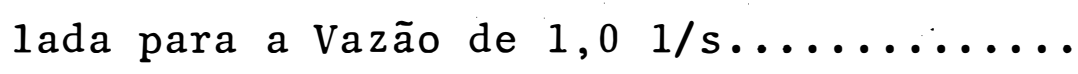

FIGURA 9 - Curvas de Infiltrações Instantânea e Acumu lada para a Vazão de $0,501 /$ s..........

FIGURA 10-Curvas de Infiltrações Instantânea e Acumu

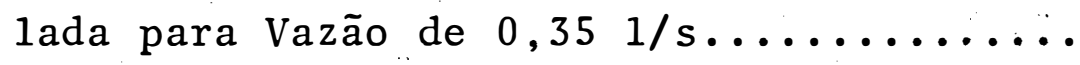


FIGURA 11 - Representação Grâfica dos Perfis Molhados para os Tratamentos I, II e III.........

FIGURA 12 - Sulcos e Lâminas de Agua Provenientes da 1. Irrigação, Efetuada Logo Apōs a Semea-

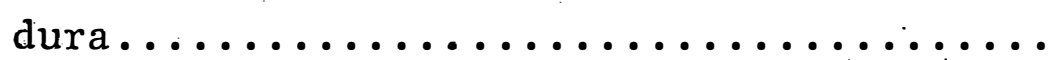

FIGURA 13 - Precipịtações Pluviométricas, Irrigações e Tensões da Água no Sollo às Profundida-. des de 15,30 e $45 \mathrm{~cm}$ durante o Ciclo Fenológico do Feijão Irrigado por Sulco: Início do Tratamento I..............

FIGURA 14 - Precipitações Pluviométricas, Irrigações e Tensões da Agua no Solo às Profundidades de 15,30 e $45 \mathrm{~cm}$ durante o Ciclo Fenológico do Feijão Irrigado por Sulco.

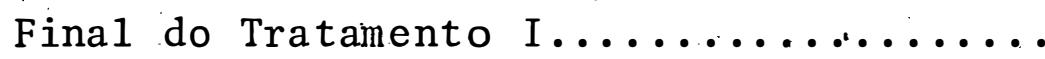

FIGURA 15 - Precipitações Pluviométricas, Irrigações e Tensões da Água no Solo às Profundidades de 15,30 e $45 \mathrm{~cm}$ durante o Ciclo Fenológico do Feijão Irrigado por Sulco. Início do Tratamento II...............

FIGURA 16 - Precipitações Pluviométricas, Irrịgações e Tensões da Água no Solo às Profundidades de 15,30 e $45 \mathrm{~cm}$ durante o Ciclo Fenológico do Feijão Irrigado por Sulco.

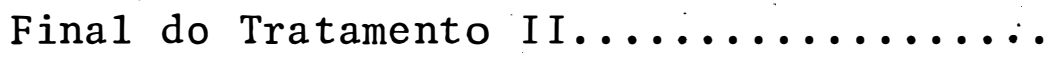


FIGURA 17 - Precipitações Pluviométricas,. Irrigações

e. Tensões da Agua no Solo às Profundidades de 15,30 e $45 \mathrm{~cm}$ durante o Ciclo Fenológico do Feijão Irrigado por Sulco.

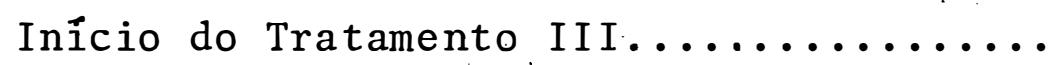

FIGURA 18 - Precipitações Pluviomêtricas, Irrigações e Tensões da Agua no Solo às Profundidades de 15,30 e $45 \mathrm{~cm}$ durante o Ciclo. Fenológico do Feijão Irrigado por Sulco.

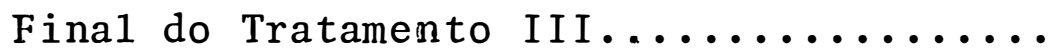

FIGURA 19 - Precipitações Pluviiométricas, Irrigações e Tensões da Agua no Solo às Profundidades de 15,30 e $45 \mathrm{~cm}$ durante o Ciclo Fenológico do Feijão Irrigado por Sulco. Início do Tratamento IV.............

FIGURA 20 - Precipitações Pluviomētricas, Irrigações e Tensões da Agua no Solo às Profundidades de 15,30 e $45 \mathrm{~cm}$ durante o Ciclo Fenológico do Feijão Irrigado por Sulco.

Final do Tratamento IV..............

FIGURA 21.- Peso da Matéria Secia cia Parte Aérea ao Longo do Ciclo do Feijoeiro Cultivar Aroa na 80 , sob 4 Tratamentos de Irrigação por Sulco, nas Posições: Início, Meio e Final. de Sulco 
Pảgina

FIGURA 22 - Indice de Area Foliar (IAF) ao Longo do Ciclo do Feijoeiro Cultivar Aroana 80, sob 4 Tratamentos de Irrigação por Sulco, nas Posições Início, Meio e Final de Sulco...... 62 


\section{DESENVOLVIMENTO DO FEIJOEIRO (Phaseolus valgaris L.) SUBMETIDO A DIFERENTES LÂMINAS MEDIAS \\ DE ĀGUA ATRAVES DA IRRIGAÇÃO POR SULCO}

Marcos Vinícius Folegatti Orientador: Prof. Dr. Antonio Sanchez de Oliveira

RESUMO

0 presente trabalho teve como objetivo analisar o desenvolvimento do feijoeiro, sob diferentes lâminas médias de água atravēs da irrigação por sulco.

Para o desenvolvimento do experimento foi consi derada a declividade de $0,6 \%$ no sulco e adotadas as vazões de $0,35 \mathrm{l} / \mathrm{s}$ e $1,0 \mathrm{l} / \mathrm{s}$, sendo que esta ủ1tima, após o avanço, foi reduzida para $0,5 \mathrm{l} / \mathrm{s}$. As. lâminas médias aplicadas foram de $53,80,33,30$ e $27,30 \mathrm{~mm}$ em cada uma das quatro irrigações e para três tratamentos correspondentes, respectivamente, a 100 , 50 e $0 \%$ de lâmina ütil no final do sulco. Um quartó tratamento empregado serviu de testemunha e não recebeu irrigação. o delí. neamento experimental foi o de 5 blocos casualizados e 4 trata mentos com sub-parcelas em classificação hierárquica, 
A cultivar utilizada foi a Aroana 80, semeada em 15/06/84, tendo a emergência ocorrida em 26/06/84 e a co1heita em 22/09/84. As irrigações foram efetuadas sempre que se esgotasse a lâmina útil aplicada de $21 \mathrm{~mm}$, sendo a evapo transpiração controlada por intermédio de um : tanque clas se A instalado na ārea experimental.

Através dos resultados obtidos nos ensaios de infiltração, estabeleceram-se as equações de i infiltraçãọ $\mathrm{I}=\mathrm{K} \cdot \mathrm{T}^{\mathrm{n}}$ e de avanço $\mathrm{T}=\mathrm{a}\left(\mathrm{e}^{\mathrm{bx}}-\mathrm{1}\right)$, para cada tratamento irrigado.

Os parâmetros de crescimento que diferiram sig nificativamente entre os tratamentos foram: produção de grãos, número de grãos por vagens, número de ramificações por planta, comprimento de caule e matéria seca da parte aérea por 10 plantas, número de vagens por planta.

Nos tratamentos de 50 e $0 \%$ de lâmina útil no final do sulco, apesar da anālise estatística não ter revelado diferenças significativas entre os parâmetros de crescimento obtidos para os segmentos início, meio e final do sulco, nota se, um decréscimo nos seus valores, do início para o final do súlco. Ao que tudo indica essas diferenças foram ocasionadas pelos períodos de seca ocorridos no crescimento vegetativo e no florescimento, uma vez que as lâminas d'água adicionadas pe la irrigaçã̃o foram insuficientes. Verificou-se também um retar damento de 8 dias na maturação fisiológica. 
DEVELOPMENT OF BEAN (Phaseolus vulgaris L.) IRRIGATED BY F FURROWS 'WITH DIFFERENT AVERAGE WATER DEPTHS

Marcos Vinícius Folegatti Adviser: Dr. Antonio Sanchez de Oliveira

SUMMARY

The scope of this experiment was to ascertain the development of bean crop under different average depths of water by furrow irrigation.

The slope of furrows was set to $0,6 \%$ and the flow adjusted to 0.35 and $1.01 / \mathrm{sec}$. The last figure was reduced to $051 / \mathrm{sec}$. at the end of water advance in the furrows.

Average depths of water in each irrigation were of $53.80,33.30$ and $27.30 \mathrm{millimeters,} \mathrm{corresponding}$ respectively to 100,50 and $0 \%$ of available water at the end of furrows. The control was kept without irrigation. Statistical outline was in randomized blocks with four 
treatments and sub-p1ots.

Sowening of Aroana 80 cultivar was on June 15, 1984, emerging by June 26, and the harvesting was made on september 22. Twenty one millimeters of effective water depth was applied in each irrigation and evapotranspiration controlled by class A pan evaporation.

For each treatment the infiltration and advance equations were established from infiltration tests. Significant difference among. treatments was detected for grain yield, number of grains per pod, number of. branches per plant, stem length and dry matter from ten plants.

Ripening was delaied up to 8 days due to insufficient irrigation'in some plots, including the control. 
1. INTRODUÇÃO

O feijão comum (Phaseolus vulgaris L.) è produto de grande importância para o Brasil como fonte de proteína na dieta alimentar de sua população.

Na década de 70 , apesar das áreas cultivadas com feijão terem se expandido significativamente em relação ao decêe nio anterior, a produção brasileira manteve-se praticamente inalterada, em virtude de queda pronunciada na produtividade. Es te comportamento, aliado ao aumento populacional, provocou substancial redução na produção per capita, de mais de $26 \mathrm{~kg} / \mathrm{habi-}$ tante por ano para aproximadamente $18 \mathrm{~kg} /$ habitante por ano, no período anos 70 e início de 80 (VIEIRA e GATTI, 1983). A baixa produtividade média registrada de $500 \mathrm{~kg} / \mathrm{ha}$, decorre, principal mente da irregularidade ou deficiência das precipitações pluviométricas. 
Essa produtividade pode ser elevada com a utilização da irrigação por sulco, que constitui o processo mais conhecido e utilizado em todo o mundo, abrangendo cerca de $70 \%$ das áreas irrigadas, os elementos mais importantes a serem considerados são a infiltração e a velocidade de avanço da água no sulco. As inter-relações destes fatores são influenciadas pe la vazão, tipo de solo, declividade do terreno, comprimento : e espaçamento do sulco e duração da irrigação.

0 conhecimento destes elementos constitui um embasamento importante na escolha e avaliação de critérios para o manejo correto da aplicação da água às culturas por este método.

0 objetivo principal deste trabalho é o de estudar o desenvolvimento do feijoeiro, sob diferentes lâminas médias de água empregadas na irrigação por sulco. 


\section{REVISAOO DA LITERATURA}

\subsection{Avaliação da Irrigação}

A Equação de KOSTIAKOV (1932) è bastante utilizada para determinar a equação para irrigação por sulcos de in filtração e pode ser expressa por:

$$
\mathrm{I}=\mathrm{K} \cdot \mathrm{T}^{\mathrm{n}}
$$

onde :

$$
\begin{aligned}
& \mathrm{I}=\text { intensidade de infiltração; } \\
& \mathrm{T}=\text { tempo de irrigação; } \\
& \mathrm{K} \text { e } \mathrm{n}=\text { constantes. }
\end{aligned}
$$


CRIDDLE et alii (1956), observaram que o tempo de infiltração pode ser determinado a partir da integração da equação $\dot{I}=K \cdot \mathrm{T}^{\mathrm{n}}$, chegando-se à seguinte expressão: $\cdot$.

$$
T=\left[\frac{60 h(n+1)}{K}\right]^{\frac{1}{n+1}}
$$

onde:

$$
\begin{aligned}
& \mathrm{h}=\text { quantidade de âgua infiltrada; } \\
& \mathrm{T}=\text { tempo de infiltração; } \\
& \mathrm{K} \text { e } \mathrm{n}=\text { coeficiente e expoente experimentais. }
\end{aligned}
$$

GRAY e BEER (1957), verificaram que a intensida de de infiltração da âgua no. solo pode variar através do comprimento do sulco devido ao decréscimo progressivo da superfície molhada e às variações da estrutura do solo ao longo do sulco. Esses autores estabeleceram uma equação para o cálculo do avanço da äguá nos sulcos de irrigação: .

$$
\mathrm{T}=\mathrm{K} \cdot \mathrm{D}^{\mathrm{n}}
$$

onde:

$$
\begin{aligned}
& \mathrm{T}=\text { tompo de avanço (min) } \\
& \mathrm{D}=\text { distância do avanço (m) } \\
& \mathrm{K} \text { e } \mathrm{n}=\text { constantes }
\end{aligned}
$$

THORTON (1961) trabalhando com irrigação por sulcos de infiltração de forma, declividade e rugosidade diver sas e sob diferentes vazões, verificou que a forma apresentada 
pelo sulco tem considerável influência sobre o avanço da água.

HANSEN et alii (1953) afịmam que a baixa efic்i ência de distribuição d'água ou sua inadequada aplicação è, na maioria das vezes, a causa da baixa produtividade em algumas āreas irrigadas. Nenhum aspecto da eficiência de irrigação pode ser abandonado, para que se possa ter o máximo rendimento na produção.

HANSEN (1960) distinguiu vārios tipos de eficiências na irrigação por sulcos, entre elas a eficiência de aplicação, de armazenamento e de distribuição.

A eficiência de aplicação é a estimativa da porcentagem do total de água aplicada na irrigação que é consi derada ūtil às culturas, sendo calculada pela seguinte expressão :

$$
\begin{gathered}
\mathrm{Ea}=\frac{\mathrm{L}}{\mathrm{Lm}} \times 100 \\
\mathrm{Lm}=\frac{\mathrm{Ta} \times \mathrm{qi}+(\mathrm{Ti}-\mathrm{Ta}) \mathrm{gr}}{\mathrm{C} \times \mathrm{e}} \times 60
\end{gathered}
$$

onde:

$$
\begin{aligned}
\mathrm{Ea}= & \text { eficiência de aplicação }\left(\begin{array}{l}
0 \\
0
\end{array}\right) \\
\mathrm{L}= & \text { lâmina média aplicada, armazenada na } \\
& \text { zona radicular }(\mathrm{mm}) \\
\mathrm{Lm}= & 1 \text { âmina média aplicada por sulco (mm) } \\
\mathrm{qi}= & \text { vazão inicial (1/s) }
\end{aligned}
$$




$$
\begin{aligned}
\mathrm{qr}= & \text { vazão reduzida (1/s) } \\
\mathrm{Ta}= & \text { tempo de avanço (min) } \\
\mathrm{Ti}= & \text { tempo de aplicação da āgua no início } \\
& \text { do sulco (min) } \\
\mathrm{C}= & \text { comprimento do sulco (m). } \\
\mathrm{e}= & \text { largura da faixa umedecida no } \operatorname{sulco~(m).~}
\end{aligned}
$$

A eficiência de armazenamento (Ear) é definida como a porcentagem da lâmina média necessária na profundidade efetiva do sistema radicular (Lu) que ficou armazenada em disponibilidade à cultura. Em muitas irrigaçõs há excesso de aplí cação trazendo como consequência perdas de água, em outras ocorire o inverso, a aplicação é deficiente. Para avaliar este problema foi proposto o conceito (Ear):

onde :

$$
\operatorname{Ear}=\frac{\mathrm{L}}{\mathrm{Lu}} \times 100
$$

$$
\begin{aligned}
& \text { Ear = eficiência de armazenamento } \\
& L u=\text { lâmina média necessária (mm) }
\end{aligned}
$$

A eficiência de distribuição (Ed) è uma estimativa da uniformidade de infiltração ao longo do sulco, sendo determinada da seguinte forma:

$$
E d=\frac{L f}{(L i+L f) / 2} \times 100
$$


onde :

$$
\begin{aligned}
& \text { Ed = eficiência de distribuição }\left(\begin{array}{l}
0 \\
0
\end{array}\right) \\
& \text { Li = lâmina infiltrada no início do sulco (mm) } \\
& \text { Lf = lâmina infiltrada no final do sulco (mm) }
\end{aligned}
$$

Para determinações das perdas por percolação e por "Runoff", BERNARDO et alii (1977) propõem as seguinte equações :

$$
\begin{aligned}
& P p=\frac{L p}{L m} \times 100 \\
& L p=\frac{L i-L f}{2}
\end{aligned}
$$

onde :

$$
\begin{aligned}
& \operatorname{Pp}=\text { porcentagem perdida por percolação } \\
& L p=\text { lâmina média percolada }(\mathrm{mm}) \\
& \operatorname{Pr}=\frac{\mathrm{Lr}}{\mathrm{Lm}} \times 100 \\
& \mathrm{Lr}=\mathrm{Lm}-(\mathrm{Lf}+\mathrm{Lp})
\end{aligned}
$$

onde :

$$
\begin{aligned}
& \operatorname{Pr}=\text { porcentagem perdida por "Runoff" } \\
& \operatorname{Lr}=\text { lâmina média equivalente a "Runoff" (mm). }
\end{aligned}
$$


Segundo RADLEY e PANOYA (1970) na maioria das vezes, a irrigação com pequena ou nenhuma perda d'āgua no final dos sulcos resulta em grandes perdas por percolação, '̇̀, nesses casos, muitas vezes, a irrigação é projetada com algum "Runoff". Para minimizar a perda por. "Runoff" em irrigação por sulcos, a vazão inicial deve ser maior possível desde que não cause erosão, devendo ser reduzida após determinado tempo.

BERNARDO et alii (1983) salientaram que uma peque na vazão poderá acarretar excesso de infiltração no início do sulco e deficiência de irrigação no outro extremo, causando baixa uniformidade de distribuição, o que provocarâ desunifor midade de produção ao longo dos sulcos. Por outro lado, grandes vazões podem provocar erosão nos sulcos e perdas excessivas por "Runoff". Os autores ainda relataram que trabalhando em solo de textura pesada, encontraram maiores valores na eficiên cia de apliçação para condições de vazão inicial reduzida.

2.2. Efeito da Irrigação na Cultura do Feijoeiro

NETTLES (1948), GODOY et alii (1966) estudando ní veis de irrigação na cultura do feijoeiro, observaram que a ir rigação complementar foi um fator decisivo no aumento da produ tividade. 
A cultura do feijoeiro ê muito sensiveí a dêfi cit hídrico em determinadas fases de desenvolvimento. Diversos autares (KATTAN è FLEMING, 1956, ROBINS e DOMINGO, 1956,. DUBETZ: e MAHALLE, 1969, MAURER et alii, 1969, HORNER e MOJTEREDI, 1970, RAGGI et alii, 1976, MTRANDA e BELMAR, 1977, MAGALHAES e MILLAR, 1978, GARRIDO et a1ii, 1979 e STANSEL e SMITTLE, 1980), estudando o comportamento do. feijoeiro submetí. do ao déficit hỉdrico, em diferentes fases do seu desenvolvimento, observaram que durante o florescimento e formação de vagens a falta de água acarreta diminuição na produção de - grãos .

ROBINS e DOMINGO (1956) observaram que o dëficit hídrico antes do florescimento tambēm reduz o número de vagens e o nümero de grãos por vagem.

GABELMAN e WILLIANS (1960) estudando a cultura do feijoeiro irrigado, observaram que a produtividade foi redu zida quando as irrigações foram abạ̣xo das necessidades da cultura, no perído da semeadura ao florescimento. Observaram tambēm que, para obtenção de produção mâxima, o solo deve ser mantido com umidade acima de $50 \%$ da "água disponível", no período do florescimento. 
BURMAN e BOHMONT (1961) em um experimento onde parcelas da cultura do feijoeiro eram irrigadas quando os potenciais matricial da água no solo atingiam $-0,05 ;-0,10$; $-0,20$ e -0,40 $\mathrm{MPa}$, observaram que no tratamento mais irrigado, houve resposta significativa em termos estatísticos sobre o peso de grãos por vagem, número de vagens pơr. planta e número de grãos por vagem em relação aos outros tratamentos.

MAC MASTER et àlii (1965) citados por SALTER e GOODE (1967), observaram que plantas de feijoeiros que receberam umidade adequada da semeadura até o florescimento, aumentá ram suas produções de sementes, e que a maturịdade das plantas foi alcançada mais cedo do que nos tratamentos com menor umidade.

MAURER et alii (1969) observaram que a produção de feijão é dependente de um adequado suprimento de āgua na fa se de formação de vagens, porêm para a máxima produção é neces sāria uma adequada umidade no solo na fase de prë-florescimento. No tratamento onde se aplicou água quando o solo apresenta va $88 \%$ da "água disponível", foram obtidas plantas mais altas, mais pesadas e maior número de vagens, do que o tratamento à nível de $60 \%$. As plantas produzidas em solo irrigado ao nível de $32 \%$ de "água disponível" foram pequenas e a produtividade menor do que as dos demais tratamentos. 
BERNARDO et alii (1970)' verificaram que existe efeito do nível de ăgua no solo sobre a produção do feijoeiro, pois esta diminui com o aumento da tensão de umidade no solo.

EL NADI (1970) encontrou resultados que demonstram uma particular sensibilidade das plantas de feijão com re lação à seca na fase que abrange desde a emergência até a for:mação das vagens da parte inferior da planta (40 dias), durante a qual é produzida uma considerável quantidade de flores.

RAGGI et alii-(1972) verificaram acentuado efe $\underline{i}$ to do teor de umidade no solo sobre a produção do feijoeiro. Concluíram ainda que existem fases mais críticas, sendo as da floração e frutificação mais sensiveis que a de crescimento.

BASCUR e FRITSH (1975) estudando métodos de irri gação por sulco correspondentes a todos sulcos irrigados simul taneamente, sulcos irrigados alternadamente, todos sulcos irri gados simultaneamente mas com semeadura no talude do sulco e sulcos irrigados para cada duas fileiras de plantas combinados com duas frequências de irrigação de $0,04 \mathrm{MPa}$ e 0,075 $\mathrm{MPa}$. Observaram que o número de vagens por planta e número de grãos por vagem não foram afetados pelos métodos, frequências e suas combinações, mas o peso de grãos aumentou de forma significati va com a frequência de $0,04 \mathrm{MPa}$. 
MIRANDA e BELMAR (1977) observaram que o déficit hídrico da cultura do feijoeiro nos períodos de crescimento vegetatiṿo, floração e formação de vagens não influenciou no número de vagens por planta, nem no número de grãos por vagem, afetan do, entretanto, a produção em peso de grãos e o peso de 1000 sementes. Já as frequências de irrigação, que eram feitas quan do o solo atingia 30 e $70 \%$ da "água disponível", afetaram, sig nificativamente, a produção aumentando o número de vagens por planta e o peso de 1000 sementes na safra de 1974.75 ; e a produtividade nas safras de 1974/75 e 1975/76.

CAIXETA et alii. (1978) estudando o comportamento do feijoeiro, conduzido sob quatro lâminas de âgua e três níveis de adubação, observaram efeito significativo no número de vagens por 10 plantas e na produção do feijoeiro, apenas pa ra os nîveis de água.

GARRIDO e TEIXEIRA (1978a, b) estudando o efeito da irrigação no "feijão das águas", observaram que, para o rendimento de grãos, houve aumento significativo em relação à testemunha, no tratamento em que a irrigação era feita quando a umidade do solo atingia 70\% da "água disponível". Para o"fei jão da seca" os autores observaram que os tratamentos irrigados aos níveis de 40, 60 e 80\% da "água disponíve1", ocorreu aumento significativo no rendimento de grãos em relação ao tra tamento não irrigado, e também foi observada aumento significa 
tivo para o número de vagens por planta entre a testemunha sem irrigação e o melhor tratamento.

MAGALHÃES e MILLAR (1978) estudando tolerância à seca do feijoeiro, em tratamentos que consistiam em diferentes números de dias de déficit de água, de 8 a 29 dias, usando a faixa fenológica em torno do período mais crítico, a partir da floração. Verificaram que após 14,17 e 20 dias sem irrigação, as reduções nos rendimentos foram de 20,38 e $52 \%$ respecti vamente, permanecendo quase constante até o final de 29 dias de seca. Verificaram ainda, que é possívei usar o período de maior resposta ao déficit de água para gerar a relação entré rendimento relativo e potencial matricial do solo, a qual é de importância para a definìção do nível operacional de manejo de irrigação

déficit hídrico em feijão, constatáram que o período mais crítico de falta de água foi o do início da floração à plena floração, onde os níveis de potencial matricial do solo, da ordem de $-0,5 \mathrm{MPa}$, causaram uma redução no rendimento de $36,85 \%$.

GARRIDO et alii (1979a) observaram que, em re1ação as plantas sem déficit hídrico, a produção de feijão foi reduzida em 16, 42 e $48 \%$ quando houve falta de ägua no início 
da floração, final da floração e período de formação de vagens, respectivamente.

MUIRHEAD e WHITE (1979), sustentam em seu traba lho com a cultura do feijão que o estresse de ägua em período anterior ao florescimento pode retardar a formação e a fixação das vagens, mas não tem influência nạ produção.

GUNTON e EVENSON (1980) trabalhando com estresse hỉdrico em feijão, encontraram que a produção foi reduzida em até 40\% quando o déficit ocorreu durante o florescimento.

STANSEL e SMITTLE (1980) observaram que a produ ção de grãos foi proporcional a quantidade de água no solo e que o feijoeiro foi igualmente sensivel a falta de água no so1o nas fases de desenvolvimento vegetativo, florescimento e pré-florescimento.

MILLAR e CHOUDHURY (1980) através de vários estudos conduzidos no Centro de Pesquisa do Trópico Semi-Árido em Petrolina (PE), observaram que de 80 a $90 \%$ do potencial de produção da cultura do feijoeiro, são obtidos com um manejo de irrigação, no qual se fornece água ao solo quando o mesmo apre sentar um potencial matricial de $-0,17$ a $-0,075 \mathrm{MPa}$, respectí vamente. 
STANSEL e SMITTLE (1980) observaram que o manejo da água no solo para a profundidade de $0-30 \mathrm{~cm}$ foi adequado para altas produtividades de grãos, embora a planta tenha também extraído água da camada de $30-35 \mathrm{~cm}$ do perfil do solo.

MACK e BONANNO (1981) estudando o comportamento da cultura do feijoeiro sob três regimes de irrigação, onde fọ ram aplicados 63,$5 ; 116,8$ e $241,3 \mathrm{~mm}$, durante todo o cịclo, ob servaram que a produtividade da parcela mais irrigada foi de 6 a 7 vezes maior que a parcela de menor umidade e intermediäria, respectivamente. 0 nümero de vagens por planta foi 4,6, 3,6 e 12,0 para os tratamentos que receberam 63,$5 ; 116,8$ e $241,3 \mathrm{~mm}$, respectivamente.

Um mecanismo apresentado por várias leguminosas para escapar aos periodos de estresse hỉdrico é o paraheliotró pico, que serve para diminuir a temperatura da folha sob estresse e presumivelmente evitar novas perdas de água. 0 grau de manifestação deste mecanismo segundo LAWN (1982 a, b e c) é diferente segundo as espëcies e variedades.

DUBETZ (1969) estudou o fenômeno de paraheliotropismo em folhas de feijoeiro condicionados ao estresse hídrico. Após trinta dias da emergência, o solo deixou de receber irrigação e alcançou a tensão da ägua de $-0,8 \mathrm{MPa}$ entre o $300^{\circ}$ e o $40^{\circ} \mathrm{dia}$, onde as temperaturas máximas variaram de $31^{\circ} \mathrm{C}$ a $36^{\circ} \mathrm{C}$ e as plantas apresentaram o fenômeno de paraheliotro- 
pismo. Este processo foi reversível, sendo que as folhas volta ram à posição anterior no início do dia, e este comportamento somente foi observado nas plantas estressadas.

2.3. Distribuição do Sistema Radicular do Feijoeiro

$$
\text { INFORZATO e MYASAKÁ. (1963) estudando a distri- }
$$
buição do sistema radicular do feijoeiro em dois tipos de solos do Estado de São Paulo, observaram que os dez primeiros centỉmetros do perfil continham $74,5 \%$ das raízes, e os primeiros $20 \mathrm{~cm}, 83,6 \%$.

DASBERG e BAKKER (1970) constạtaram a influência da aeração e da umidade do solo no crescimento das raízes do feijoeiro, sendo que, quanto maior a umidade e menor a aera ção menor o desenvolvimento radicular das plantas, sendo o inverso também verdadeiro.

REICHARDT et alii (1974) em experimento de campo com o feijoeiro mediram semanalmente a distribuição do distema radicular, verificando que $90 \%$ das raízes estavam confina das nos $30 \mathrm{~cm}$ superiores do perfil do solo. 
3. MATERIAIS E METODOS

3.1. Local, C1ima e Solo

0 experimento foi conduzido na ärea experimental do Departamento de Engenharia Rural da Escola Superior de Agricultura "Luiz de Queiroz" - USP, em Piracicaba-SP, a uma latitude de $22^{\circ} 42^{\prime} 30^{\prime \prime}$ sul, longitude de $47^{\circ} 38^{\prime} 00^{\prime \prime}$ oeste e alti tude de $576 \mathrm{~m}$.

O clima da região é o Cwa, pela classificação climătica de Köppen, ou seja, sub-tropical úmido com estiagem no inverno, com temperatura média do mês mais frio inferior a $18^{\circ} \mathrm{C}$ e a do mês mais quente superior a $22^{\circ} \mathrm{C}$, também denominado de tropical de altitude (PAES DE CAMARGO et alii, 1974). 
0 solo do local foi descrito e classificado por RANZANI et alii (1966) como terra roxa estruturada, sërie Luiz de Queiroz, cujo material de origem são rochas bảsicas. Pela classificação americana (EUA, 1975) è um "oxic paleudalf".

3.2. Determinação dos Parâmetros do Solo

3.2.1. Granulometria e Densidade

A anālise granulomêtrica e o peso específico aparente das amostras representativas das profundidades de 0-20, 20-40 cm foram determinados no laboratório de Física de Solos do Departamento de Engenharia Rural da E.S.A. "Luiz de Queiroz", (Tabela 1).

TABELA 1 - Granulometria, Classe Textural e Peso Específico. Aparente.

\begin{tabular}{|c|c|c|c|c|c|}
\hline $\begin{array}{l}\text { Profundi- } \\
\text { dade } \\
(\mathrm{cm})\end{array}$ & $\begin{array}{c}\text { Argila } \\
\left(\frac{0}{0}\right)\end{array}$ & $\begin{array}{c}\text { Silte } \\
\left(\begin{array}{l}0 \\
0\end{array}\right)\end{array}$ & $\begin{array}{l}\text { Areia } \\
\left(\begin{array}{l}0 \\
0\end{array}\right)\end{array}$ & $\begin{array}{l}\text { Classe } \\
\text { Textura } 1\end{array}$ & $\begin{array}{l}\text { Peso Especifi- } \\
\text { co. Aparente/ } \\
\text { g.cm }\end{array}$ \\
\hline $0-20$ & 55 & 17 & 28 & Argila. & $1 ; 40$ \\
\hline $20-40$ & 53 & 17 & 29 & Argila & $.1,42$ \\
\hline & & ... & & & \\
\hline
\end{tabular}


3.2.2. Curva de Retenção e Agua Disponîve1

0 estudo da água do solo foi desenvolvido', em amostras à profundidade de $15-30 \mathrm{~cm}$. No 1aboratório de Física de Solos do Departamento de Engenharịa Rural da ESALQ, foi determinada a curva característica da āgua do s.o1o, de acordo com a metodologia estabelecida por RICHARDS (1947) e com o auxỉlio de placas de pressão nos pontos de $0,01,0,1,0,3,0,7$ e 1,5 $\mathrm{MPa}$ (Figura 1). Os limites superior e inferior de ägua disponivel foram 0,35 e $0,28 \mathrm{~cm}^{3} \mathrm{de}$ ăgua/ $\mathrm{cm}^{3} \mathrm{de}$ solo, referentes às tensões de 0,01 e $0,1 \mathrm{MPa}$, respectivamente.

3.2.3. Curvas e Equações de Avanço e de Infiltração.

Os dados para a construção das curvas de avanço e infiltração foram obtidos em cinco ensaios conduzidos antes da semeadura. o tempo de avanço foi medido em cada uma das estacas, distanciadas de $10 \mathrm{~m}$, até atingir o final do sulco. Na execução dos ensaios de infiltração foram medidas as vazões de entrada e saída nos sulcos com o auxílio de calhas WSC, desenvolvidas em Washington State College, Washington USA, de acordo com as dimensões estabelecidas por CHAMBERLAIN (1952), e apropriadas para vazões de 0,07 a 2,3 1itros.se gundo.

A equação utilizada para estabelecer a curva de avanço foi a mesma utilizada por WILLAPDSON e BISHOP (1967) a 
20 .

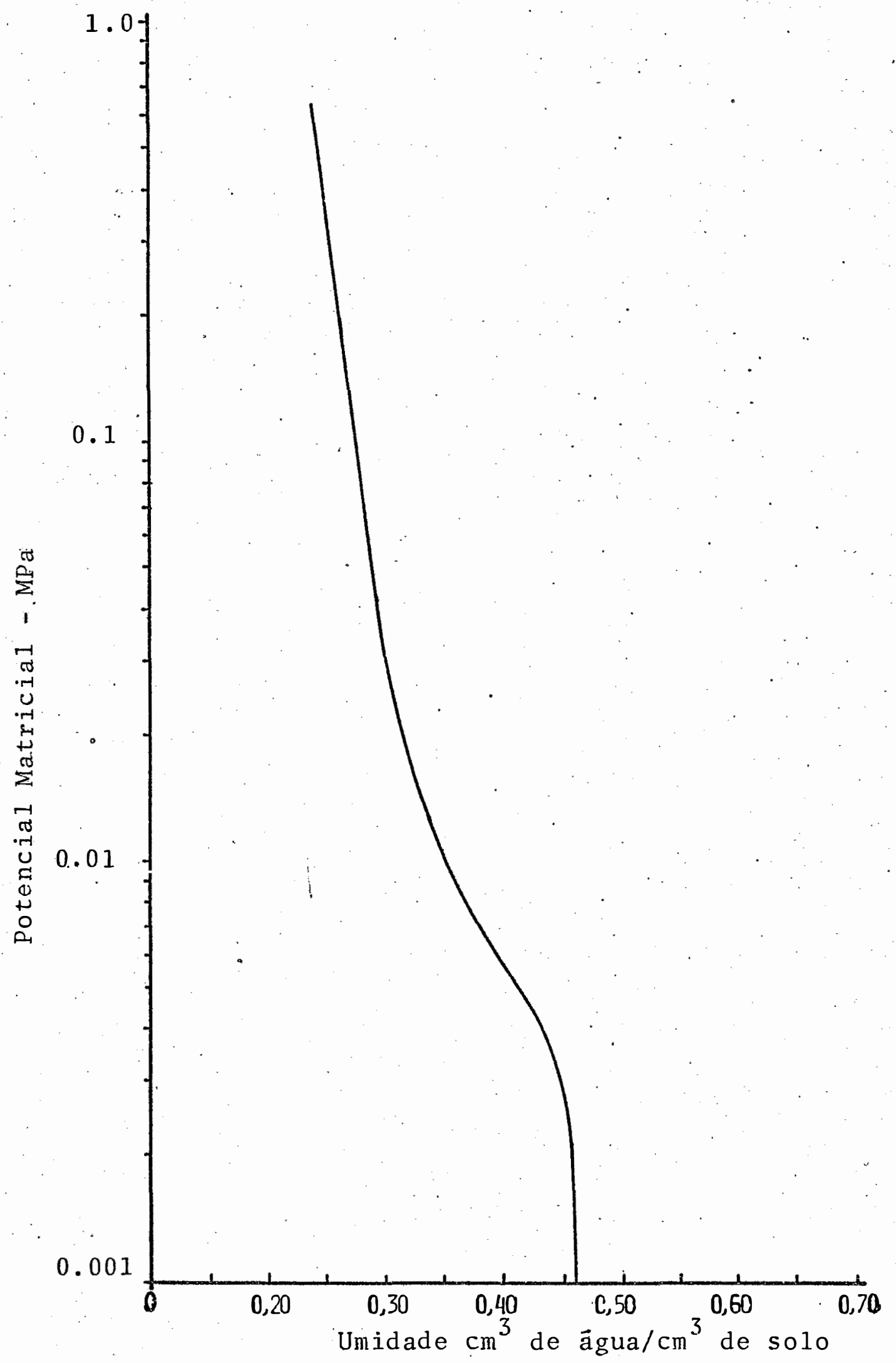

FIGURA 1 - Curva Característica da Agua no Solo. 
saber:

$$
T=a\left(e^{b x}-1\right)
$$

onde:

$$
\begin{aligned}
& \mathrm{T}=\text { tempo de avanço (min) } \\
& \mathrm{x}=\text { distância do avanço (m) } \\
& \mathrm{e}=\text { base do logaritmo }
\end{aligned}
$$

$a$ e $b=$ coeficientes experimentais

Esta expressão, alēm de determinar com precisão a intensidade de avanço, é de grande aplicabilidade, possibili tando a avaliação das alterações das características hidráulicas do sulco, pois o avanço da água no sulco, representado pela equação do avanço, está relacionado principalmente com as variāveis fundamentais da hidrāulica de irrigaçã் superficial, tais como a vazão de entrada, declividade do terreno e rugosidade do sulco.

Uma equação que representa a intensidade de in filtração da ãgua no solo, em uma forma simples e precisa, foi proposta por KOSTIAKOV (1932) e posteriormente por LEWIS (1937). Nesse método a infiltração é expressa por uma equação exponencial, da seguinte forma:

$$
i=K \cdot T^{n}
$$

onde:

$i=$ intensidade de infiltração $(\mathrm{mm} / \mathrm{h})$

$\mathrm{k}$ = constante relativa a taxa de infiltração na unidade de tempo 


$$
\begin{aligned}
& \mathrm{T}=\text { tempo de infiltração (minutos) } \\
& \mathrm{n}=\text { expoente experimental. }
\end{aligned}
$$

Desta forma, a intensidade de infiltração " foi estudada atravês da equação proposta, com a transposição dos dados de tempo e infiltração instantânea, obtidos no campo, em papel di-logarítmico. Atravês de cálculos pelos métodos dos quadrados minimos foram obtidas as constantes $\mathrm{K}$ e $\mathrm{n}$, representativas da infiltração inicial no tempo unitârio e do expoente do coeficiente angular da reta, respectivamente.

Integrando esta equação, obtem-se o tempo total em minutos necessārio a aplicação de uma determinada lâmina de ăgua :

onde :

$$
T=\left[\frac{60 \quad I \quad(n+1)}{K}\right]^{\frac{1}{n+1}}
$$

$$
\begin{aligned}
\mathrm{T}= & \text { tempo necessāio para a aplicação de } \\
& \text { uma determinada lâmina (min.) } \\
\mathrm{I}= & \text { infiltração acumulada (mm) }
\end{aligned}
$$

3.3. Instalação do Experimento

3.3.1. Sistematização do Terreno para Irrigação

Após o preparo inicial da ārea experimental com aração, gradagem e regularização com pranchão, foram traçados preliminarmente sulcos com declividades de 0,3,0,6 e 1,0\%, e 
em cada um deles testadas as vazoes de 0,3, 0,5 e 1,0 1/s. A melhor declividade encontrada foi de $0,6 \%$ para as vazões de 1,0 e $0,351 / \mathrm{s}$, e de acordo com os tratamentos. pretendidos (Fig. 2) \%.

Os declives foram obtidos por meio de nivelamen tos com demarcação de estacas a cada. 10 metros.

Os sulcos, em número de 95 , espaçados de $1,00 \mathrm{~m}$ e com as dimensões de $120 \mathrm{~m}$ de comprimento e $0,20 \mathrm{~m}$ de profundidade foram construídos com auxilio de um sulcador tracionado por trator.

3.3.2. Dados Meteorológicos

Os dados meteorológicos precipitação e evaporação, foram obtidos em um pluyiômetro e um tanque Classe A, ins talados em um Posto Meteorológico, situado aproximadamente a $15 \mathrm{~m}$ da ărea expẹrimental, em terreno coberto por grama. As medições de precipitação da evaporação, representativas das 24 horas precedentes, foram realizadas às 7 horas.

3.3.3: Suprimento de Ãgua

Para o suprimento de āgua nas irrigações foi utilizado um reservatório com cota superior a da área experimental, possibilitando a condução da água por gravidade, através de uma tubulação de $3^{\prime \prime}$ de diâmetro, até a área experimen- 


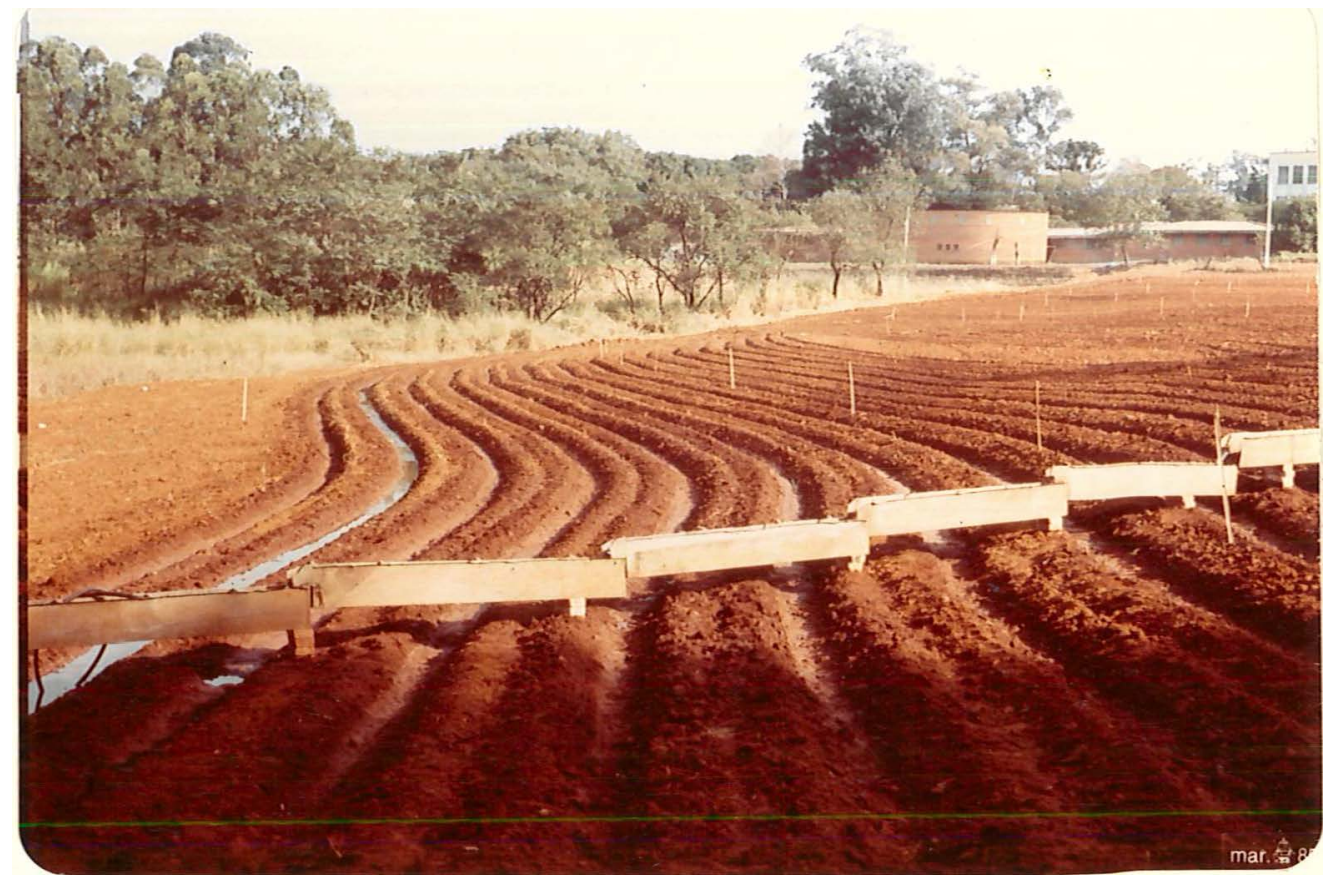

FIGURA 2 - Terreno sistematizado para irrigação, com sulcos de 0,6: de declividade, espaçados de $1,00 \mathrm{~m}$ e interceptados pelo conjunto de calhas. 
ta1. Para a distribuição de ägua na ärea foram utilizadas, a guisa de canal condutor, calhas de chapa galvanizada dispostas escalonadamente sobre o terreno (Figura 3). A distribuição da ảgua nos sulcos se fez atravês de sifões plästicos de 19,05 mm (3/4") de diâmetro (Figura 4), que despejavam a àgua em pequenos recipientes instalados no início do sulco e com a sua bor-. da superior sempre a mesma distância do nível de āgua na calha, a fim de manter a vazão constante.

3.3.4. Manejo da Irrigação

Baseando-se nas caracteristicas físicas do :so-. 1o, determinou-se a lâmina útil a ser aplicada a partir da seguinte expressão:

$$
\mathrm{h}=\frac{\mathrm{AD}}{10} \cdot \gamma_{\mathrm{s}} \cdot \mathrm{H}
$$

onde :

$$
\begin{aligned}
\mathrm{h}= & \text { altura de ägua a ser aplicada em } \mathrm{mm} ; \\
\mathrm{AD}= & \text { intervalo de âgua considerado a sen } \\
& \text { aplicado em }: \\
Y_{\mathrm{S}}= & \text { peso específico aparente em } \mathrm{g} / \mathrm{cm}^{3} \\
\mathrm{H}= & \text { profundidade do solo considerada em } \mathrm{cm} .
\end{aligned}
$$

Esta expressão permitiu o cậlculo da altura de āgua necessāria para se fornecer ao solo, que foi de $21 \mathrm{~mm}$, e com as equações determinadas nos ensaios, calculam-se os tempos teóricós de aplicação. 


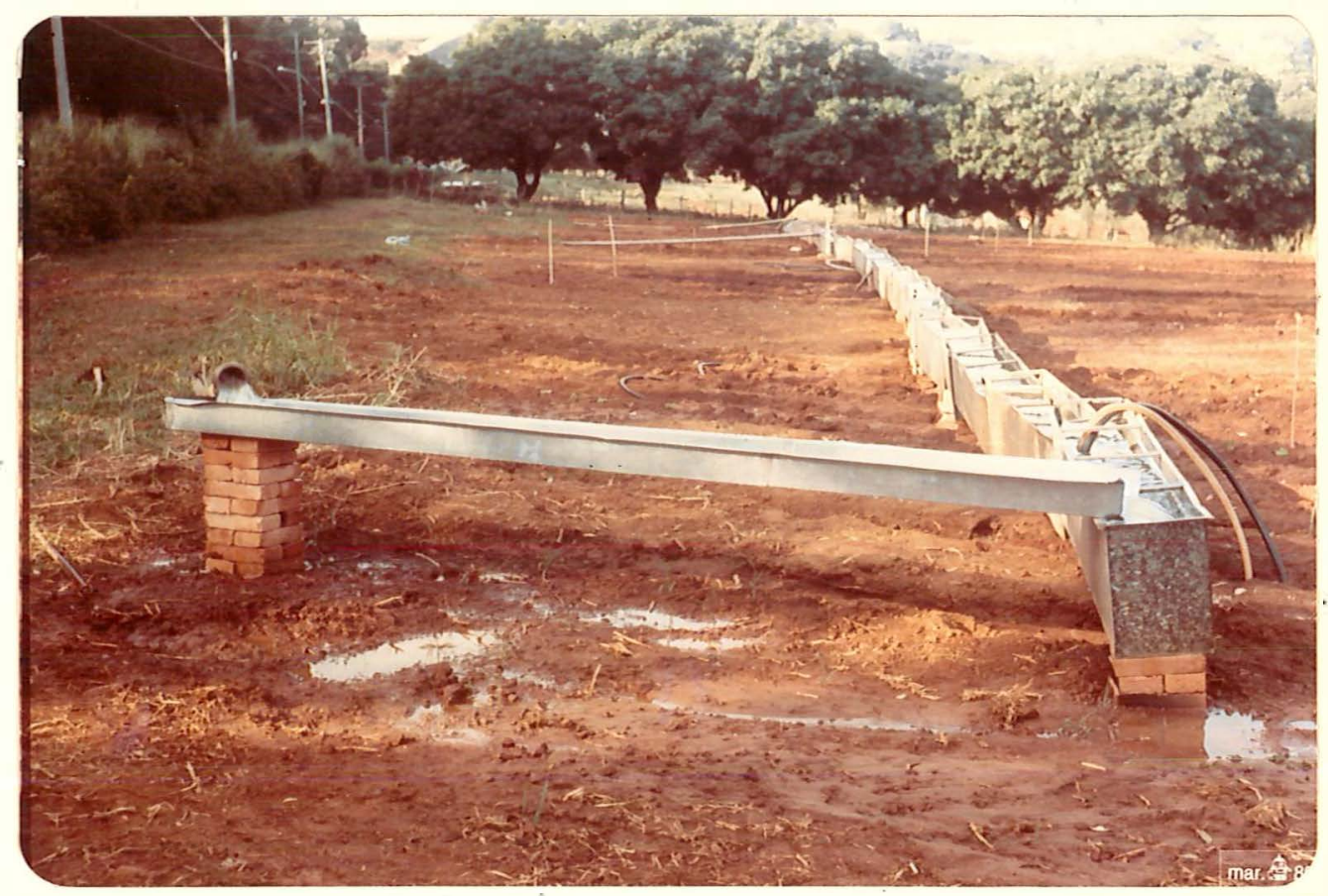

FIGURA 3 - Conjunto de Calhas de chapa de aço galvanizado dis tribuídas de maneira escalonada, à guisa de canal adutor.

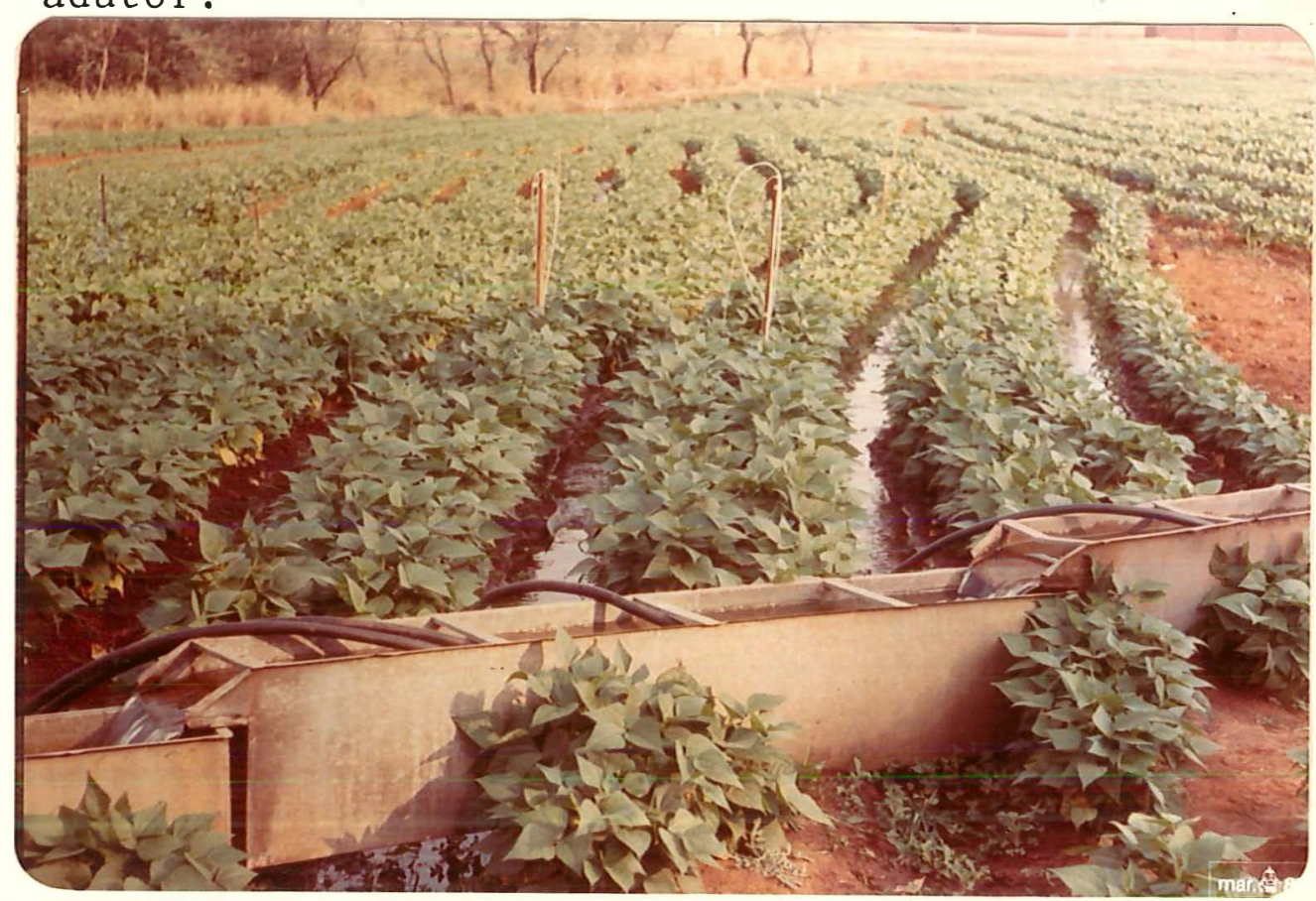

FIGURA 4 - Tensiômetros, conjunto de calhas, sifões e sulcos

em funcionamento na cultura do feijoeiro 45 dias após emergência. 
De acordo com LINDERMAN e STEGMAN (197.1), VAZI- RI e WU (1972), o tempo total de irrigação pode ser obtido diretamente com os dados de campo, atravês da expressão:

$$
\mathrm{T}=\mathrm{Tap}+\mathrm{Tav}-\mathrm{Tr}
$$

onde :

$$
\begin{aligned}
& \text { Tapp }=\text { tempo de aplicação em mịnutos; } \\
& \mathrm{T} \quad=\text { tempo total de irrigação em minutos; } \\
& \operatorname{Tav}=\text { tempo de avanço em minutos; } \\
& \operatorname{Tr}=\text { tempo de recesso em minutos. }
\end{aligned}
$$

O tempo de recesso foi considerado instantâneo após o têrmino do fornecimento de água nos sulcos dada a dificuldade em medi-1o.

As irrigações foram feitas todas as vezes que se esgotasse a lâmina de $21 \mathrm{~mm}$ adicionada ao solo, e controladas. através da eṿaporação do tanque "Classe A"; sendo adotados os coeficientes de cultura (Kc) igual a 0,95 FAO (1979) e de tanque (Kp) igual a 0,80 .

\subsubsection{Tensiômetros}

Foi instalada em um bloco escolhido ao acaso. uma bateria de tensiômetros, para acompanhar o potencial matricial da água no solo nas diversas fases da cultura e nos diversos tratamentos. Os tensiômetros foram instalados junto a 
linha de plantas, a $10 \mathrm{~m}$ do sulco e a $100 \mathrm{~m}$ de distância, e nas profundidades de 15,30 e $45 \mathrm{~cm}$. As leituras também foram realizadas diariamente às 7 horas.

\subsection{Belineamento Experimental}

No experimento foram considerados 95 sulcos com declividade média de $0,6 \%$, dividido em 5 blocos casualizados sendo cada bloco com quatro tratamentos conforme Figura 5.

Os quatro tratamentos são descritos abaixo:

a) Tratamento I - cem por cento (100\%) da lâmina ütil (21 mm) aplicada no final do sulco.

b) Tratamento II - cinquenta por cento ( $50 \%)$ da lâmina útil $(10,5 \mathrm{~mm})$ aplicada no final do sulco.

c) Tratamento III - zero por cento ( $0 \%$ ) da 1 âmi na útil aplicada no final do sulco.

$\therefore$ d) Tratamento IV - testemunha sem irrigação.

Os tratamentos I e II foram conduzidos com a va zão de $1,01 / \mathrm{s}$ e o tratamento III com a vazão de 0,35 1/s.

Para os tratamentos I e II utilizou-se do processo de redução de vazão de 1,0 para $0,51 / \mathrm{s}$ após o avanço da água ter chegado ao final do sulco. 


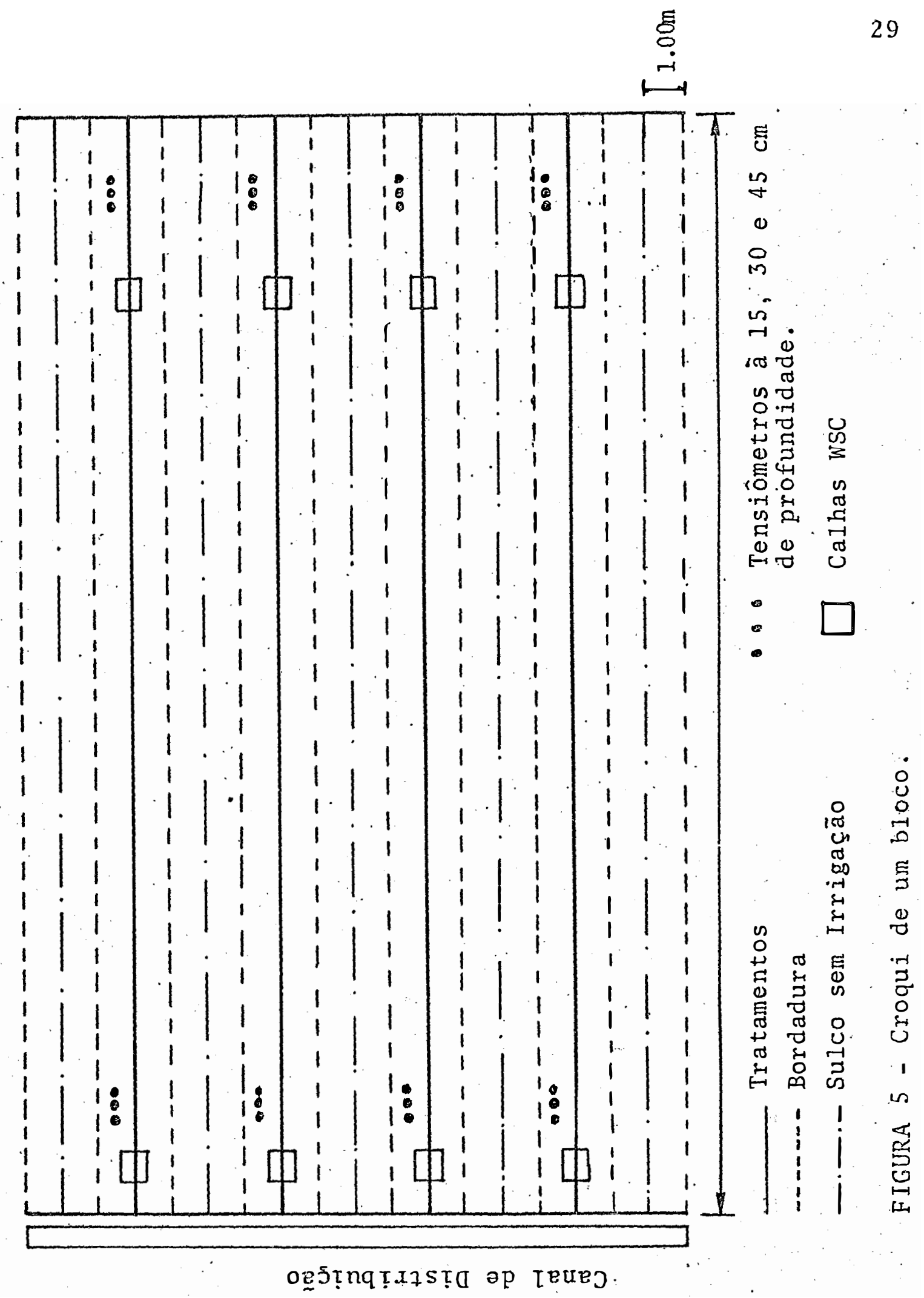


Para cada parcela dos tratamentos foram destina dos 3 sulcos consecutivos isolados nor um sulcọ sem irrigação, sendo o sulco central utilizado para avaliação e os outros dois como bordaduras.

3.5. CuI tura

Como suporte experimental foi instalada a cultu ra de feijão (Phaseolus vulgaris L.) cultivar Aroana 80, de hạ bito de crescimento indeterminado, tipo arbustivo com guia cur. ta, internódios curtos e maturação praticamente uniforme, resultante de seleções individuais em F5 do segundo retrocruzamento de (Aroana x Cornell 49-22) x Aroana (São Paulo, 1982). Esta cultivar pode ser enquadrada no grupo "chumbinho", com início da floração entré 35 e 40 dias após a emergência e ciclo total (semeadura a colheita) entre 90 a 100 dias.

\subsubsection{Semeadura e Tratos Culturais}

A semeadura foi efetuada com plantadeira adubadeira ma nual, ao longo de sulcos com $120 \mathrm{~m}$ de comprimento e espaçados de $1,00 \mathrm{~m}$, distribuỉa em fileiras duplas dẹ plantas com espaçamento dentro das fileiras de $0,40 \mathrm{~m}$, entre fileiras de $0,60 \mathrm{~m}$ e entre plantas na fileira de $0,10 \mathrm{~m}$. Ficando dessa maneira um sulco entre cada duas fileiras duplas de plantas. Procurou-se obter em torno de 200.000 plantas por hectare, o que correspon de aproximadamente 10 plantas por metro linear,Figura 4. 
A adubação fosfatada foi feita na base de 400 $\mathrm{kg} / \mathrm{ha}$ de superfosfato simples, e a adubação nitrogenada sob a forma de sulfato de amônio foi apliçada 25 dias após a emẹgên cia na quantidade de $100 \mathrm{~kg} / \mathrm{ha}$.

Ao longo de todo o período experimental foram. efetuadas, três capinas manuais, para controle de plantas daninhas, e uma aplicação de inseticida (18/07) para controle. da mosca branca (Bemisia tabaci).

\subsubsection{Fenologia.}

Durante o ciclo do feijoeiro foram. feitas observa ções de fenoloğia a nível diārio, caracterizando-a segundo o método descrito por FEHR e CAVINESS (1977) para a soja. A esco 1ha deste método se deve à clareza com que se pode caracterizàr. as diversas fases de desenvolvimento da cultura.

\subsubsection{Anālise dos Parâmetros de Crescịmento}

Foram coletadas em média a cada 10 dias e em ca da tratamento, amostras de plantas contidas em $1,00 \mathrm{~m}$ de file ra ou $0,50 \mathrm{~m}^{2}$, para cada três sub-parcelas localizadas ao redor das estacas 20,60 e $100 \mathrm{~m}$; as amostras foram lavadas em água corrente e secadas em estufa a $60-70^{\circ} \mathrm{C}$, a fim de se determinar: 
- peso total da parte aẹ́rea, sub-dividida em pe so de folhas secas, caules + pecíolos e vagens + grãos.

- Indice da ārea foliar (IAF), foi utilizado um vazador de ärea conhecida igual a $1,58 \mathrm{~cm}^{2}$. Correlacionou-se o peso referente a ārea de 50 discos com o peso seco de folhas determi-: nando-se a ārea foliar, que a seguir foi correlacionada com $0,50 \mathrm{~m}^{2}$ de solo.

Na última coleta foram medidos, alêm dos parâme tros acima citados, o número de nós por plantas, o número de ramificações por planta, o número de vagens por planta, o núme ro de grãos por planta, o nümero de grãos por vagem e a matéria seca total da parte aérea.

Para maior precisão na avaliação da produtivida de foram coletadas plantas numa ārea de $10 \mathrm{~m}^{2}$ ao longo das posições dos tratamentos que a seguir foram trilhadas; amostras dessas parcelas foram secadas em estufa a $60-70^{\circ} \mathrm{C}$ para a determinação do peso seco que a seguir foi corrigido para $14 \%$.

\subsection{Anālise Estatísticà}

Para os diferentes parâmetros de crescimento foi processada a anālise estatística em blocos casualizados com sub-parcelas em classificação hierārquica: 


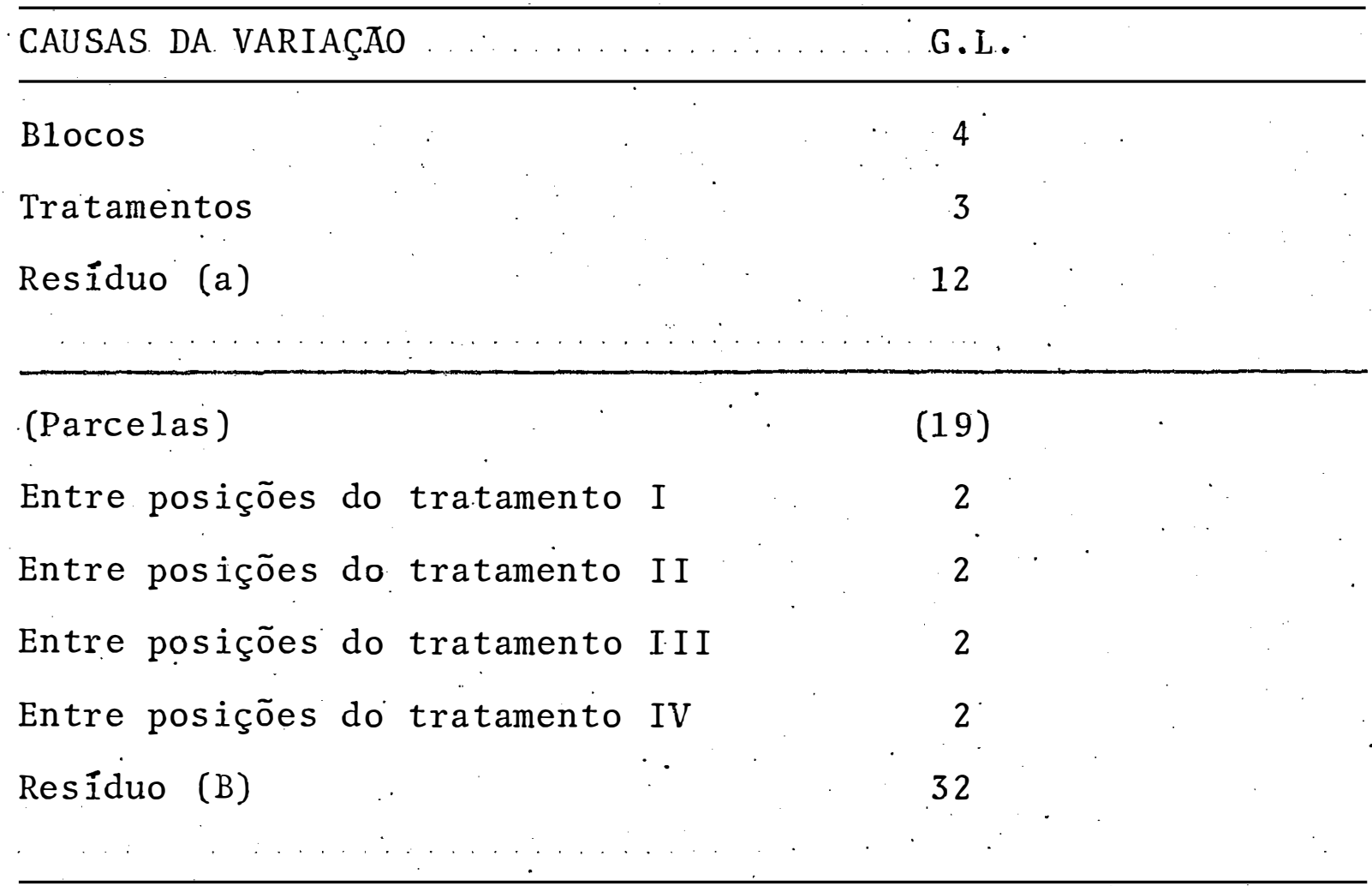

T 0 T A 
4. RESULTADOS E DISCUSSAOO

4.1. Curva de Avanç.o

Os tempos de avanço para a água percorrer os $120 \mathrm{~m}$, para as vazões de 1,0 e $0,351 / \mathrm{s}$, foram 33,0 e 155,5 minutos, respectivamente. Os dados mëdios dos tempos de avanço para cada estaca são apresentados na Tabela 2 .

Na Figura 6 è possivel verificar os desvios apresentados pelos dados obtidos em relação as curvas de avanço calculadas por meio das equações $T=12,31\left(e^{0,011 x}-1\right) \mathrm{e}$ $\mathrm{T}=26,87\left(\mathrm{e}^{0,016 \mathrm{x}}-1\right)$, para as vazões de 1,0 e $0,351 / \mathrm{s}$, re $\underline{s}$ pectivamente.

Observou-se que da primeira para a quarta irr $\underline{i}$ gação houve um aumento no tempo de avanço, mostrando uma vari ação das características hidráulicas dos sulcos causadas pelo 
TABEIA 2 - Valores Médios dos Tempos de Avanço da Agua no Sulco de $12.0 \mathrm{~m}$ para as Vazões de 1,0 é $0,351 / \mathrm{s}$.

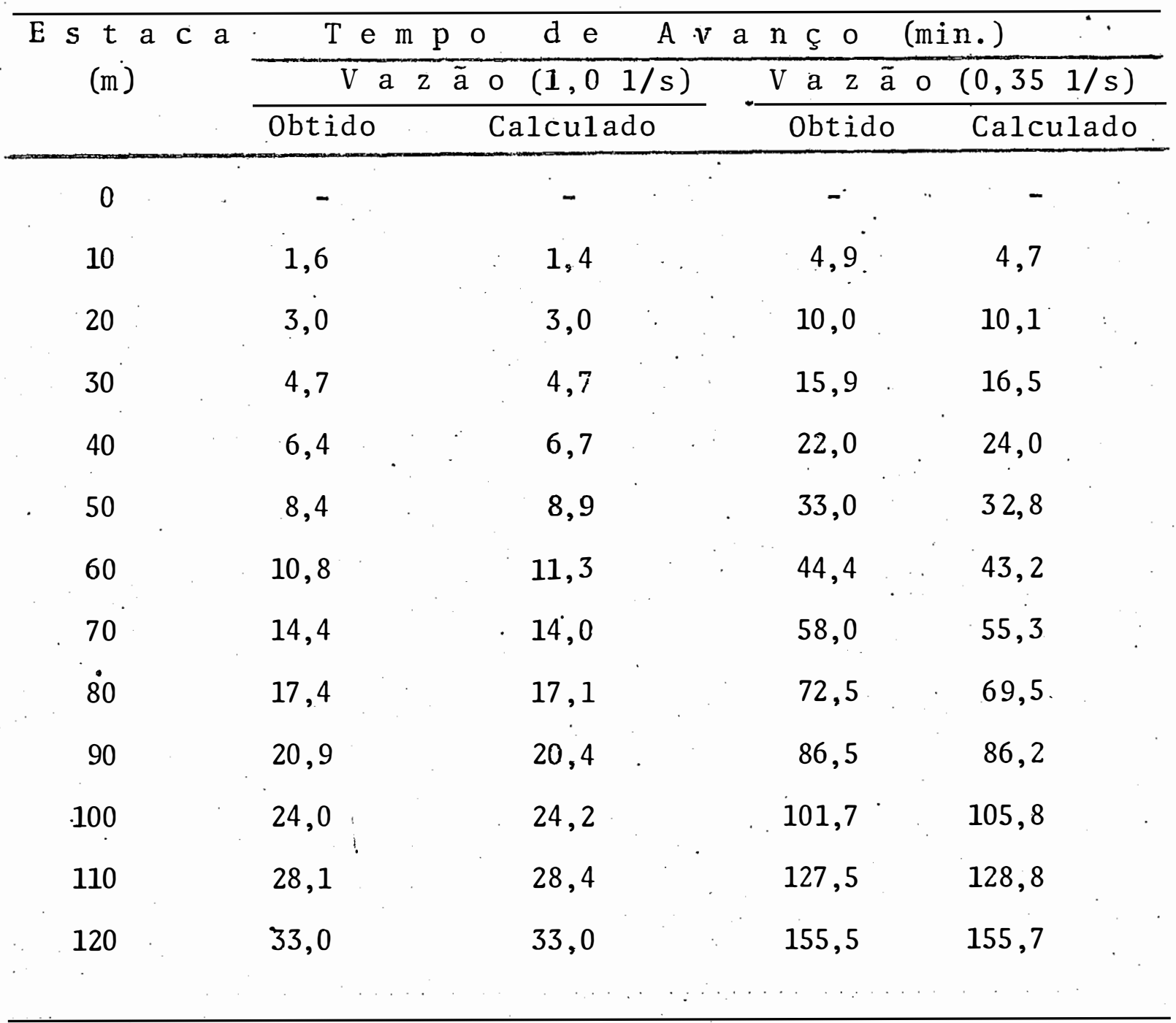

Equação do Avanço:

$$
\begin{array}{rr}
\mathrm{T}=12,31\left(\mathrm{e}^{0,011 x}-1\right) & \mathrm{T}=26,87\left(\mathrm{e}^{0,016 \mathrm{x}}-1\right) \\
\mathrm{r}^{2}=0,99876 & \mathrm{r}^{2}=0,99974
\end{array}
$$




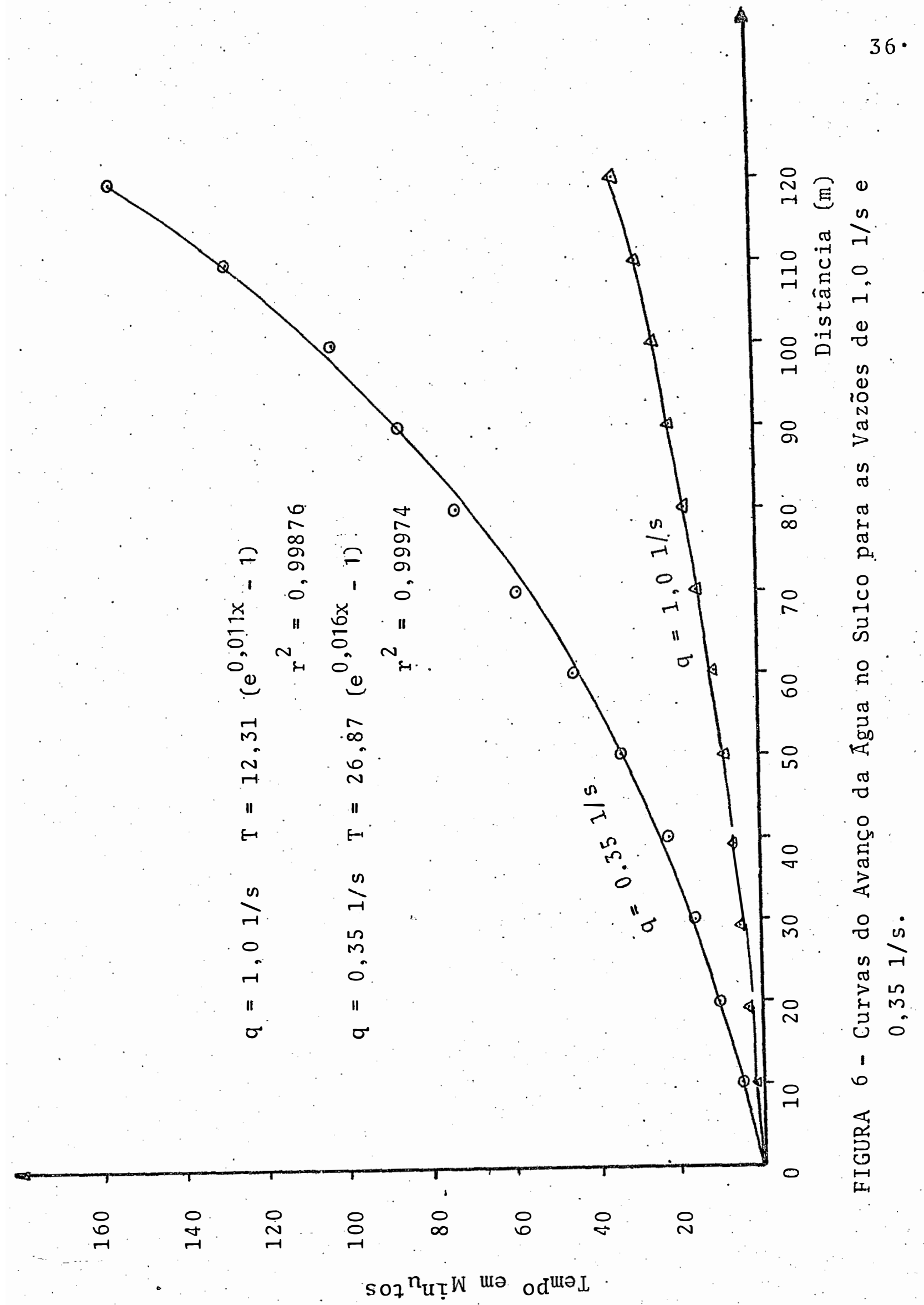


desenvolvimento da cultura, fato também verificado por VAZIRI et alii (1973), AZEVEDO et alii (1975) e sOUZA (1977).

4.2. Curva de Infiltração

As curvas de velocidade de infiltração da āgua no solo (Figura 7), para as vazões de $1,0,0,5$ e $0,351 / \mathrm{s}$, res pectivamente, foram construídas a partir dos dados das Tabelas 3,4 e 5. Comparando-se as velocidades de infjutração. bãsica observa-se que estas diminuíram com a diminuição das vazões, conforme os valores $14,1,7,56$ e $6,84 \mathrm{~mm} / \mathrm{h}$.

Por integração da infiltração instantânea, determinaram-se as equações de infiltração acumulada $I=0,56 \mathrm{~T}^{0,85}, I=0,27 \mathrm{~T}^{0,87}$ e $\mathrm{I}=0,21 \mathrm{~T}^{0,89}$ para as vazões de $1,0,0,50$ e $0,351 / \mathrm{s}$, respectivamente (Figuras 8,9 e 10). Verificou-se que, para a aplicação da lâmina útil de $21 \mathrm{~mm}$, responsável pela elevação da umidade da camada de $30 \mathrm{~cm}$ de solo à capacidade de campo, os tempos de irrigação para os tratamentos I, II e III foram $182,07,100,20$ e 155,5 minutos, respectivamente, sendo que os tratamentos I e II após o avanço, sofreram redução de vazão para $0,501 / \mathrm{s}$.

\subsection{Avaliação da Irrigação}

Conforme Tabela 6 , com as equações de avanço e de infiltraç̃̃o determinou-se a, lâmina de irrigação para cada 


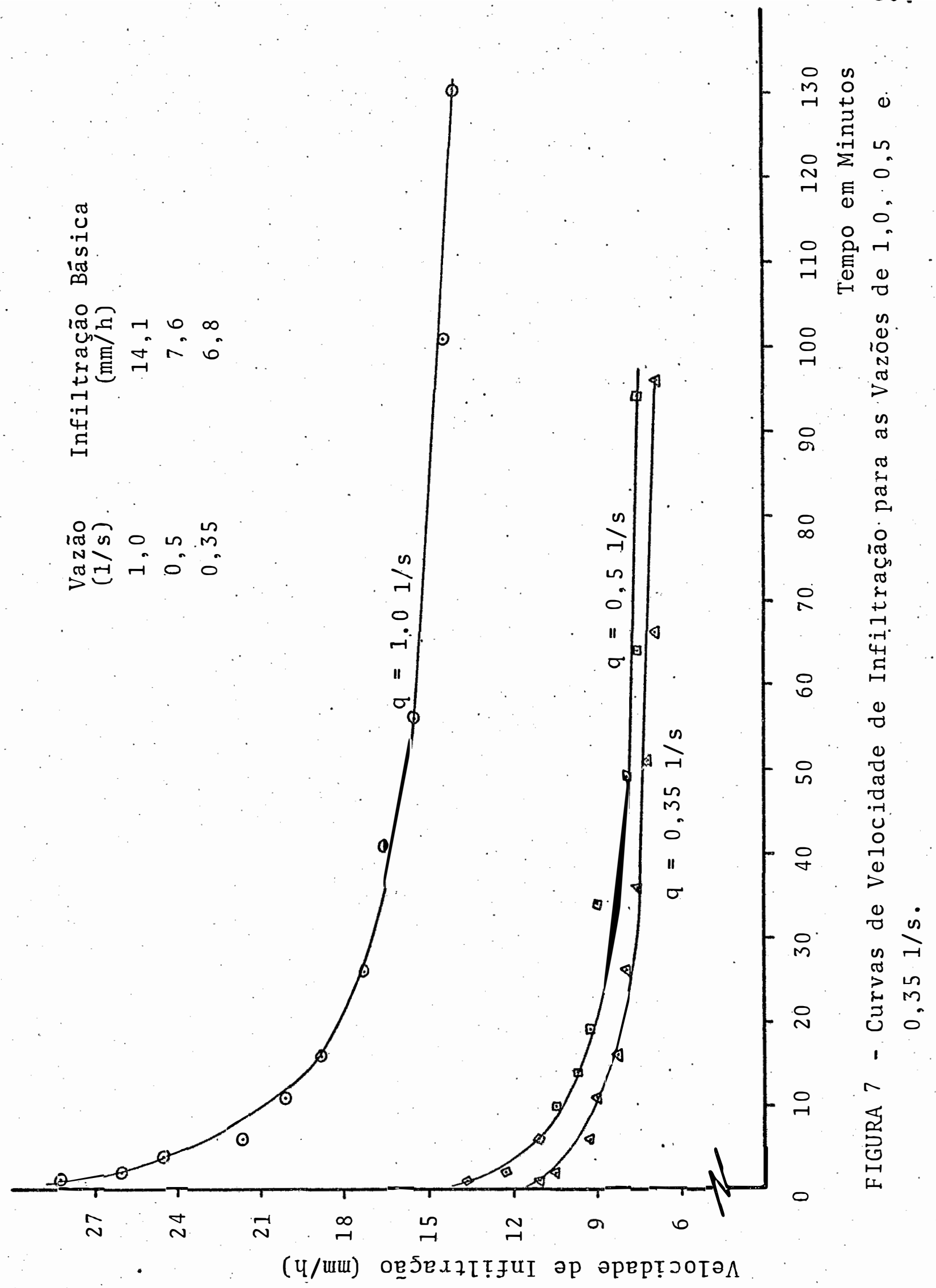


39.

TABELA (3) - Dados Mẻdios da Velocidade·de Infiltração da Agua no Solo para Vazão de $1,01 / \mathrm{s}$

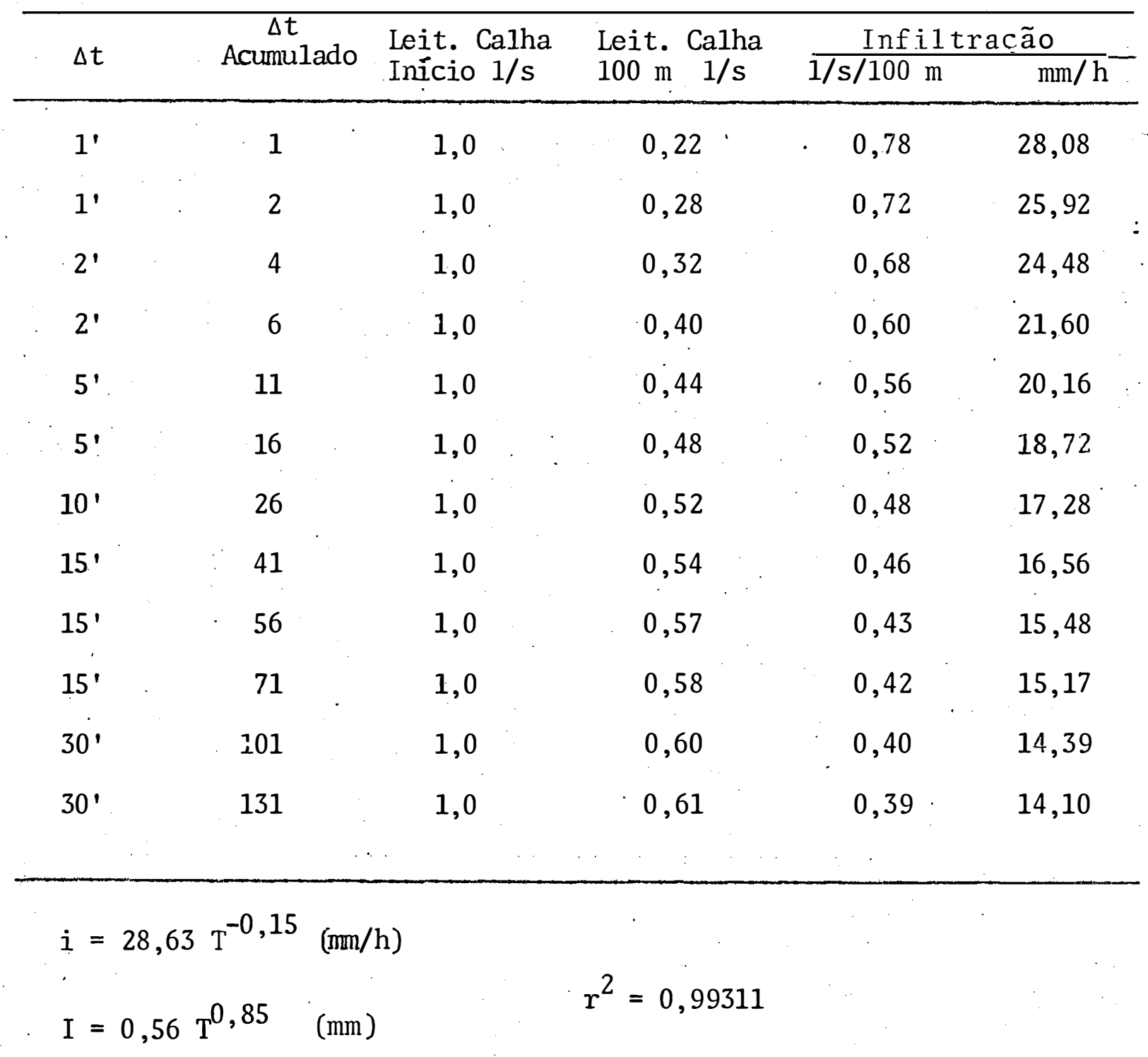


TABElA (4) - Dados Médios da Velocidade de Infiltração da Ãgua no Solo para Vazão de $0,501 / \mathrm{s}$.

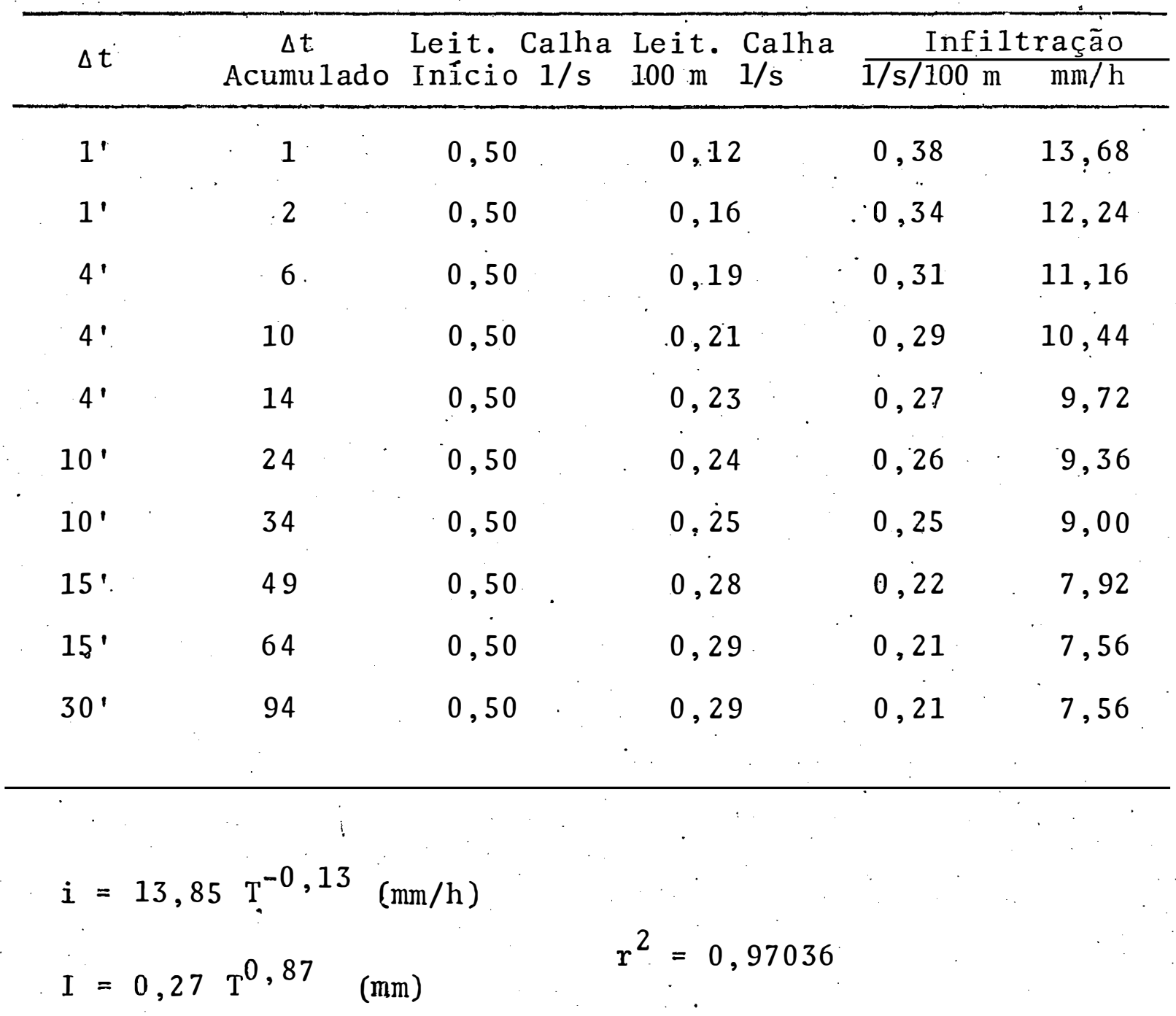


TABELA (5) - Dados Médios da Velocidade de Infiltração da Agua no Solo para Vazão de $0,351 / \mathrm{s}$.

\begin{tabular}{|c|c|c|c|c|c|}
\hline \multirow{2}{*}{$\Delta t$} & \multirow{2}{*}{$\begin{array}{c}\Delta t \\
\text { Acumulado }\end{array}$} & \multirow{2}{*}{$\begin{array}{l}\text { Leit. Calha } \\
\text { Início }(1 / \mathrm{s})\end{array}$} & \multirow{2}{*}{$\begin{array}{l}\text { Leit. Calha } \\
100 \mathrm{~m} \cdot(1 / \mathrm{s})\end{array}$} & \multicolumn{2}{|c|}{ ! Infiltração } \\
\hline & & & & $1 / \mathrm{s} / 100 \mathrm{~m}$ & $\mathrm{~mm} / \mathrm{h}$ \\
\hline $1^{\prime}$ & 1 & 0,35 & 0,04 & 0,31 & 11,16 \\
\hline $1^{\prime}$ & 2 & 0,35 & 0,06 . & 0,29 & 10,44 \\
\hline $2^{\prime}$ & 4 & 0,35 & 0,08 & 0,27 & 9,72 \\
\hline $2^{\prime}$ & 6 & 0,35 & 0,09 & 0,26 & 9,36 \\
\hline $5^{\prime}$ & 11 & 0,35 & 0,10 & 0,25 & 9,00 \\
\hline $5^{\prime}$ & 16 & 0,35 & 0,12 & 0,23 & 8,28 \\
\hline $10^{\prime}$ & 26 & 0,35 & 0,13 & 0,22 & 7,92 \\
\hline $10^{\prime}$ & 36 & 0,35 & 0,14 & 0,21 & 7,56 \\
\hline $15^{\prime}$ & 51 & 0,35 & 0,15 & 0,20 & 7,20 \\
\hline $15^{\prime}$ & 66 & 0,35 & 0,16 & 0,19 & 6,84 \\
\hline $30^{\prime}$ & 96 & 0,35 & 0,16 & 0,19 & 6,84 \\
\hline
\end{tabular}

$i=11,38 \mathrm{~T}^{-0,11} \quad(\mathrm{~mm} / \mathrm{h})$

$$
r^{2}=0,08676
$$

$I=0,21 \mathrm{~T}^{0,89} \quad(\mathrm{~mm})$ 
42.

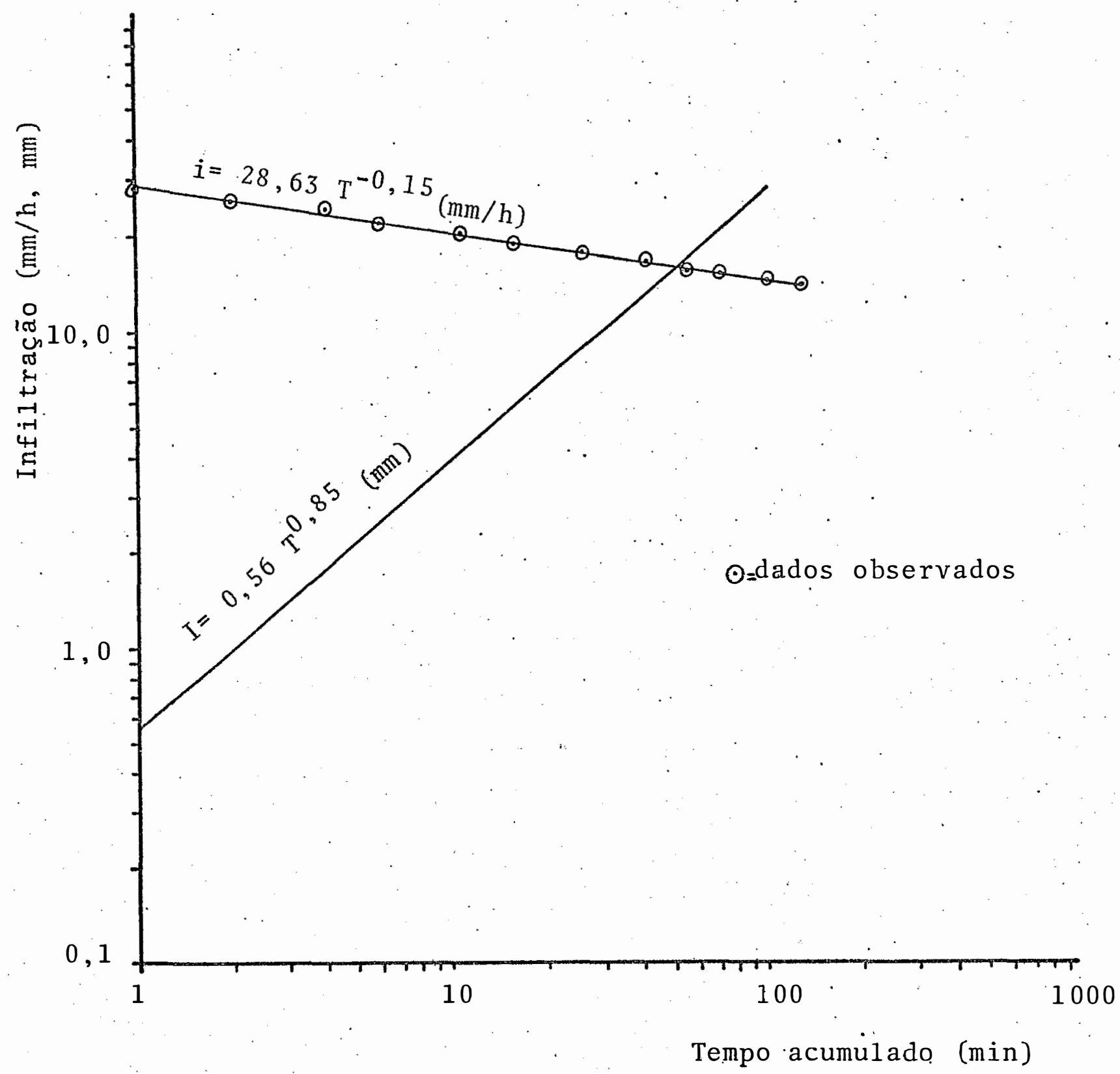

FIGURA 8 - Curvas de Infiltrações Instantânea e Acumulada para a Vazão de $1,01 / \mathrm{s}$. 


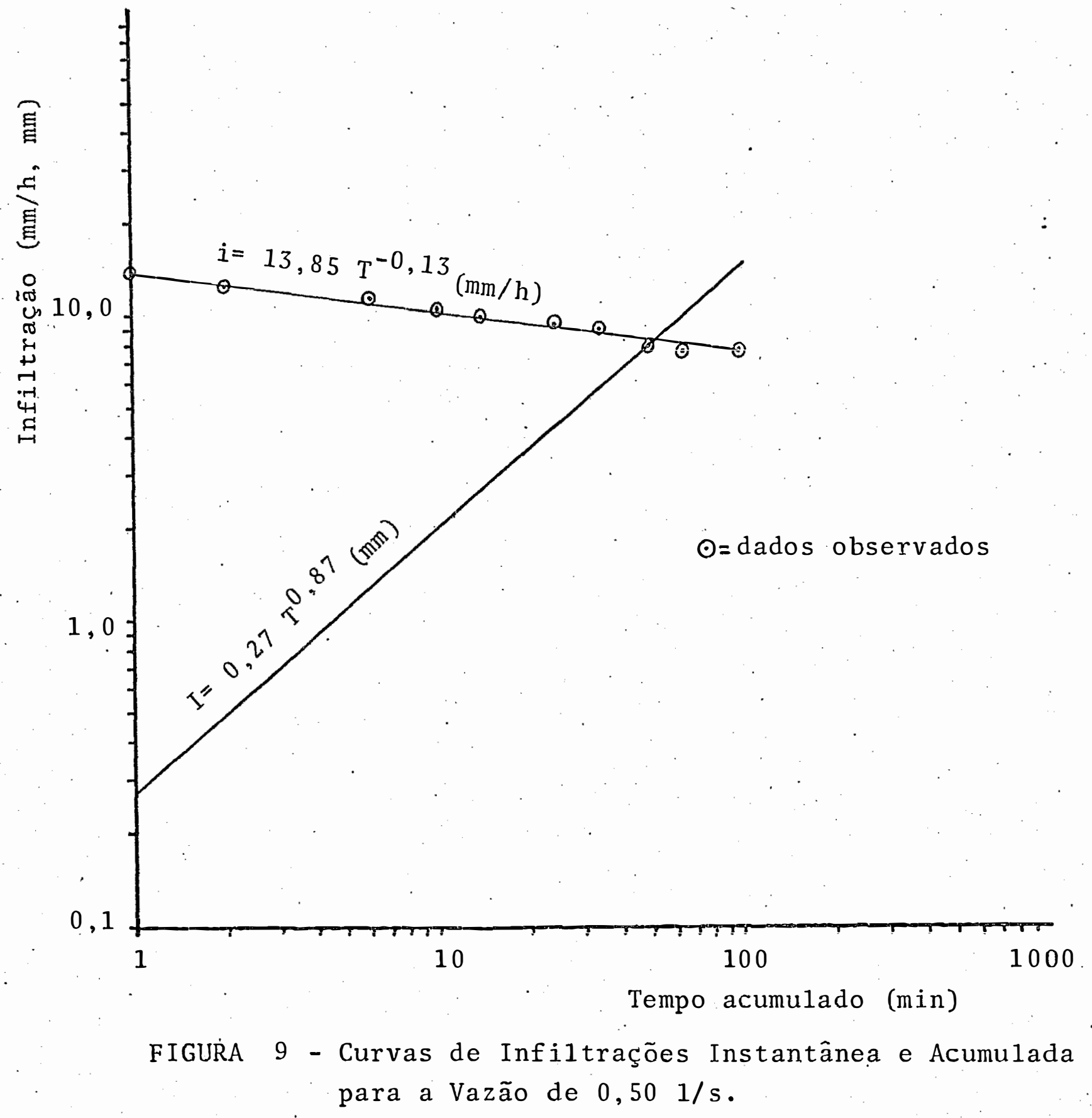




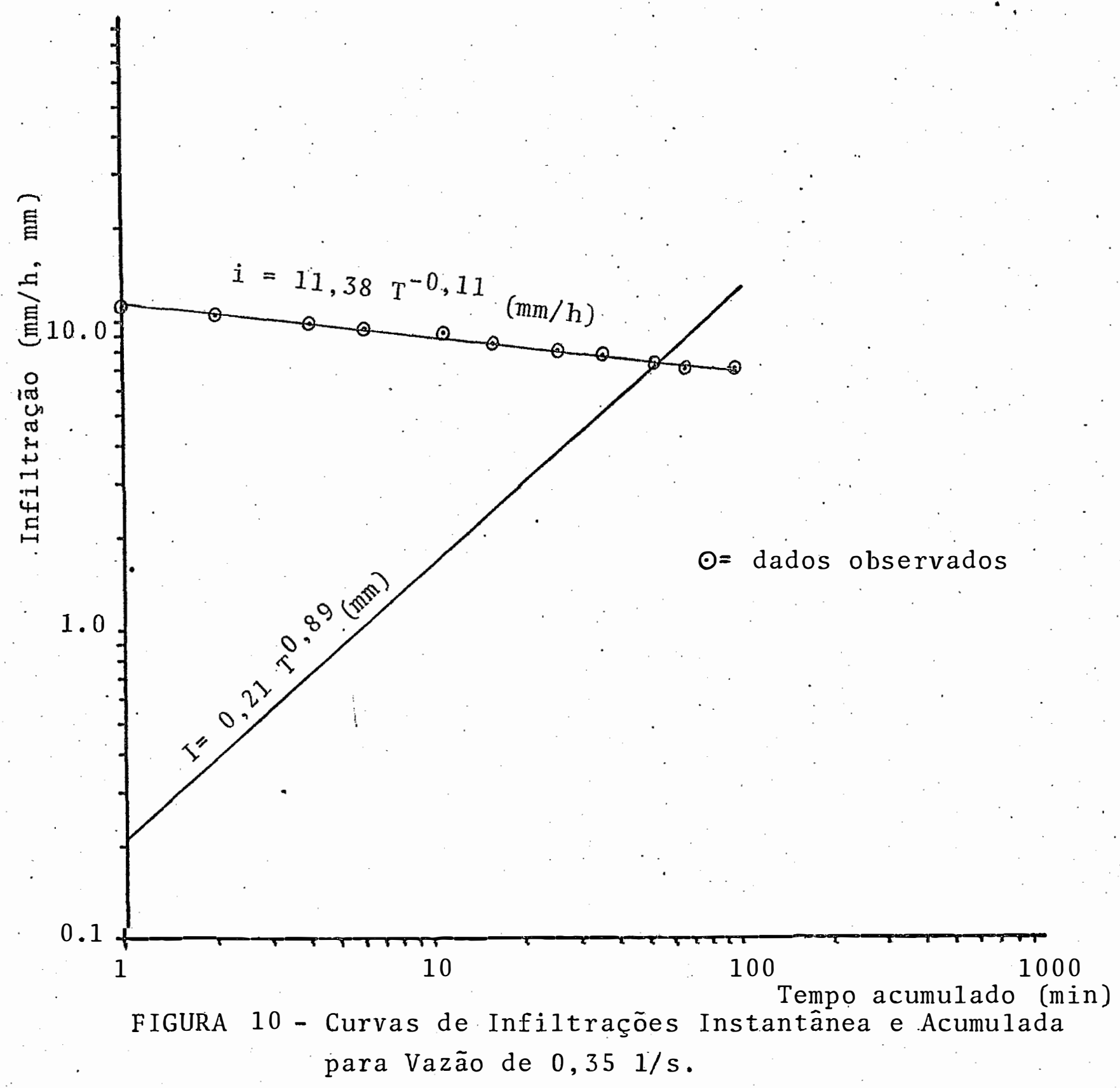


TABELA (6) - Valores da Lâmina de Irrigação para cada Estaca ao Longo ․ do Sulco para os Tratamentos I, II e İI.

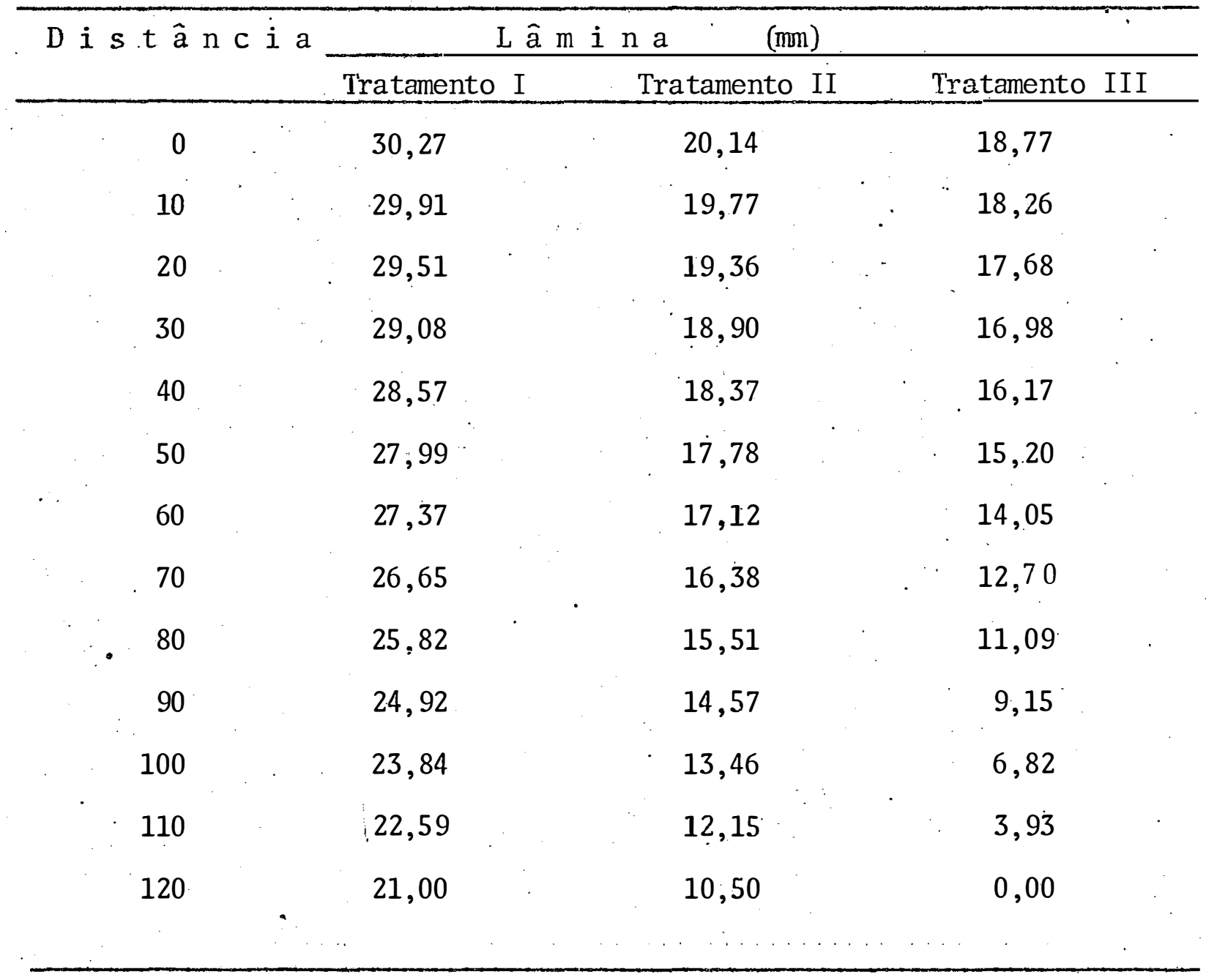


est aca ao longo do sulco, para os Tratamentós I, II e III. As re presentações gräficas dos perfis molhados para os respectivos tratamentos se encontram na Figura (11).

Para os diferentes tratamentos foram calculadas as eficiências de armazenamento (Ear), de aplicação (Ea), de distribuição (Ed) e as perdas por percolação (Pp) e por "runoff" $(\operatorname{Pr}), \quad($ Tabela 7$)$.

TABELA 7 - Eficiências de Armazenamento (Ear), de Aplicação (Ea) e de Distribuição (Ed) e Perdas por Percolação (Pp) e por Runoff (Pr).

\begin{tabular}{crrrrrr}
\hline TRATAMENTO & Ear $\left(\begin{array}{c}0 \\
0\end{array}\right)$ & Ea $\left(\begin{array}{c}0 \\
0\end{array}\right)$ & Ed $\left(\begin{array}{l}0 \\
0\end{array}\right)$ & $\operatorname{Pp}\left(\begin{array}{l}0 \\
0\end{array}\right)$ & $\operatorname{Pr}\left(\begin{array}{l}0 \\
0\end{array}\right)$ \\
\hline I & 100,0 & 39,1 & 81,9 & 8,6 & 52,3 \\
I I & 81,5 & 51,4 & 68,5 & 0,0 & 48,6 \\
I I I & 66,9 & 100,0 & 0,0 & 0,0 & 0,0 \\
\hline
\end{tabular}

De acordo com BERNARDio (1982), sob condições ideais de manejo de irrigação, circunstância verificada no tratamento I, os valores aceitáveis de eficiências de distribuição e de aplicação são de $70 \%$ e $60 \%$, respectivamente. A eficiên cia de aplicação de $39,10 \%$ obtida indica que a irrigação deveria ser conduzida com mais reduções de vazão, o que não foi feito pelo pouco aumento que traria na Ea. 

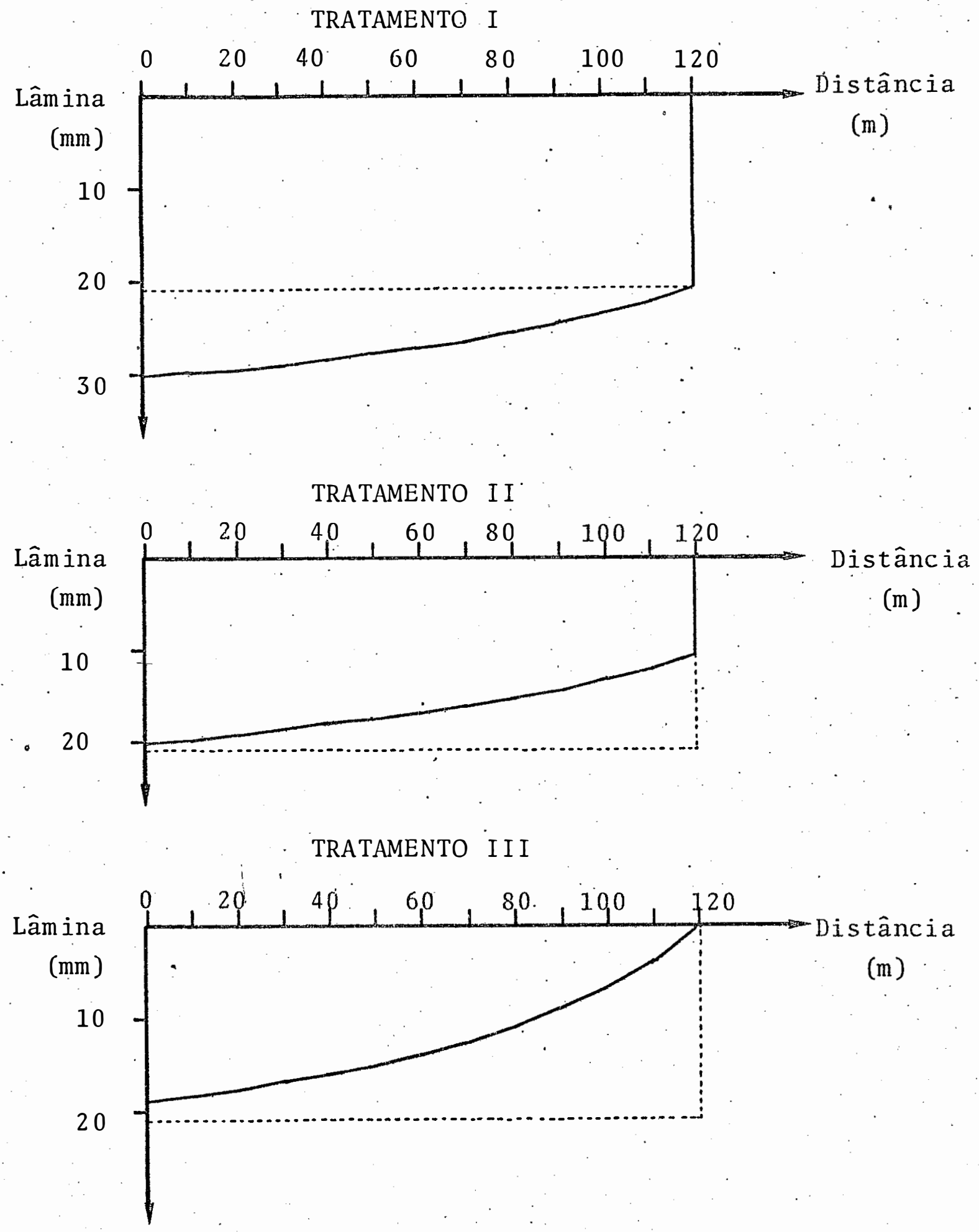

FIGURA 11 - Representação Grāfica dos Perfis Molhados para os Tratamentos I, II e III. 
Comparando-se os tratamentos I e II observa-se que, com a redução do tempo de irrigação de 182,07 para 100,20 minutos, hã uma redução nas eficiências de armazenamento de 100 para $80,95 \%$ e de distribuição de 81,92 para $68,54 \%$. Mas por outró lado há um aumento na eficiência de aplicação o que representa uma economia de $38 \%$. de água do tratamento II em relação ao I, fato evidenciaao pelas perdas do total aplicado de $61 \%$ no tratamento I e de $48,60 \%$ no tratamento II:

$$
\text { No tratamento III verifica-se a pior condição }
$$

para a cultura, uma vez que a kaixa eficiência de armazenamento acarreta em todo o comprimento do sulco, lâmina de irriga ção deficiente,embora a eficiência de aplicação seja de $100 \%$ e. as perdas nulas.

\subsection{Mane jo da Irrigação}

Como a semeadura ocorreu em período seco, nos dias 15 e 16/06, houve necessidade de se efetuar duas irrigações completas e iguais em todos os tratamentos, espaçadas de 5 dias, para proporcionar umidade suficiente à germinação, (F gura 12).

Após a emergência ocorrida. no dia 25/06, foram efetuadas quatro irrigaçōes, correspondentes aas dias 04/07, $12 / 07,23 / 07$ e $13 / 08$.

Nas Figuras (13 a 20) è possívei observar que hā défict hídrico nos tratamentos III e IV nos períodos de $26 / 06$ a $27 / 07$ (crescimento vegetativo) e de 12 a 19/08 ' (ini- 


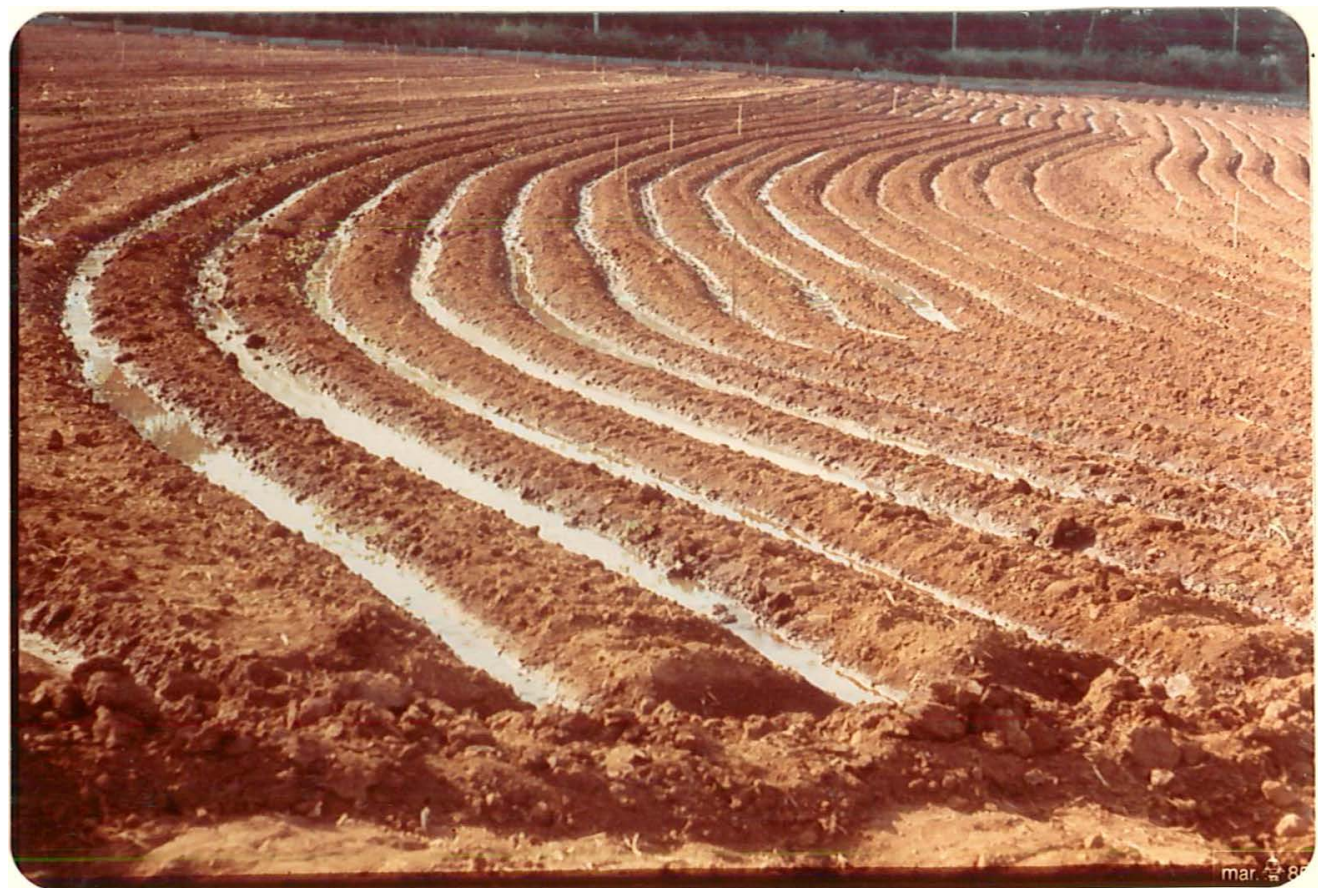

FIGURA 12 Sulcos e Lâminas de Agua Provenientes da 1. Irrigaçao, Efetuada Logo Apọ́s a Semeadura. 


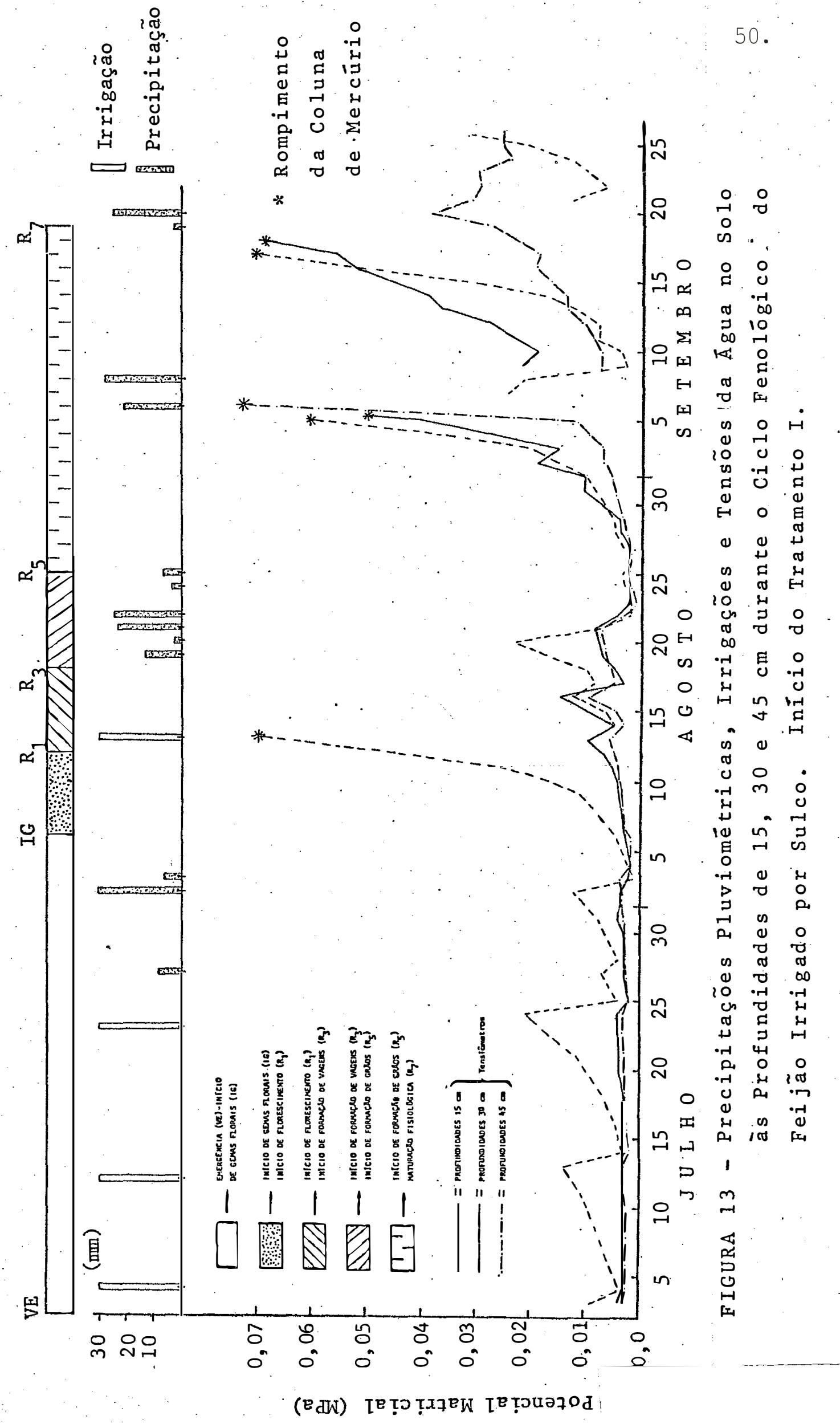




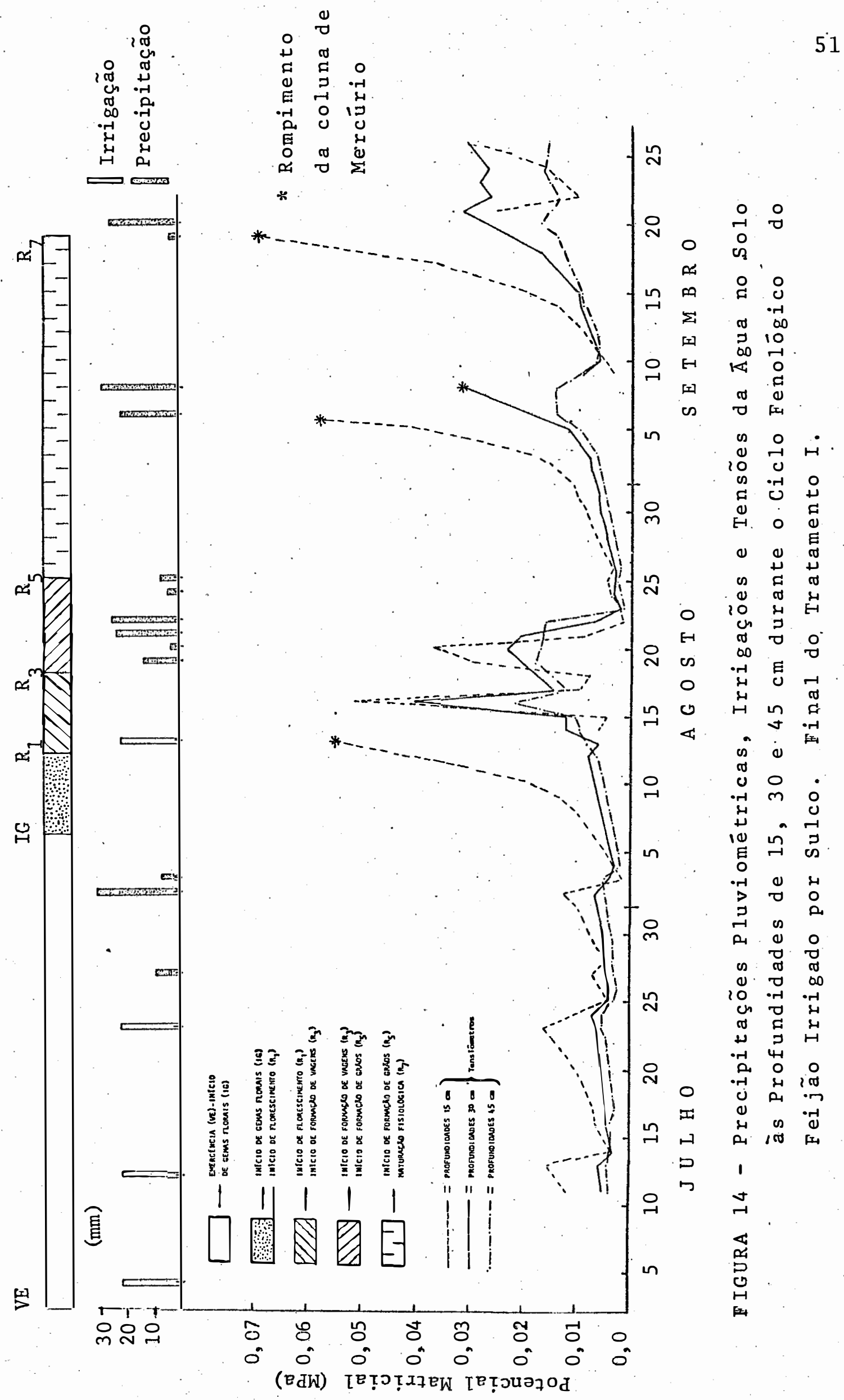




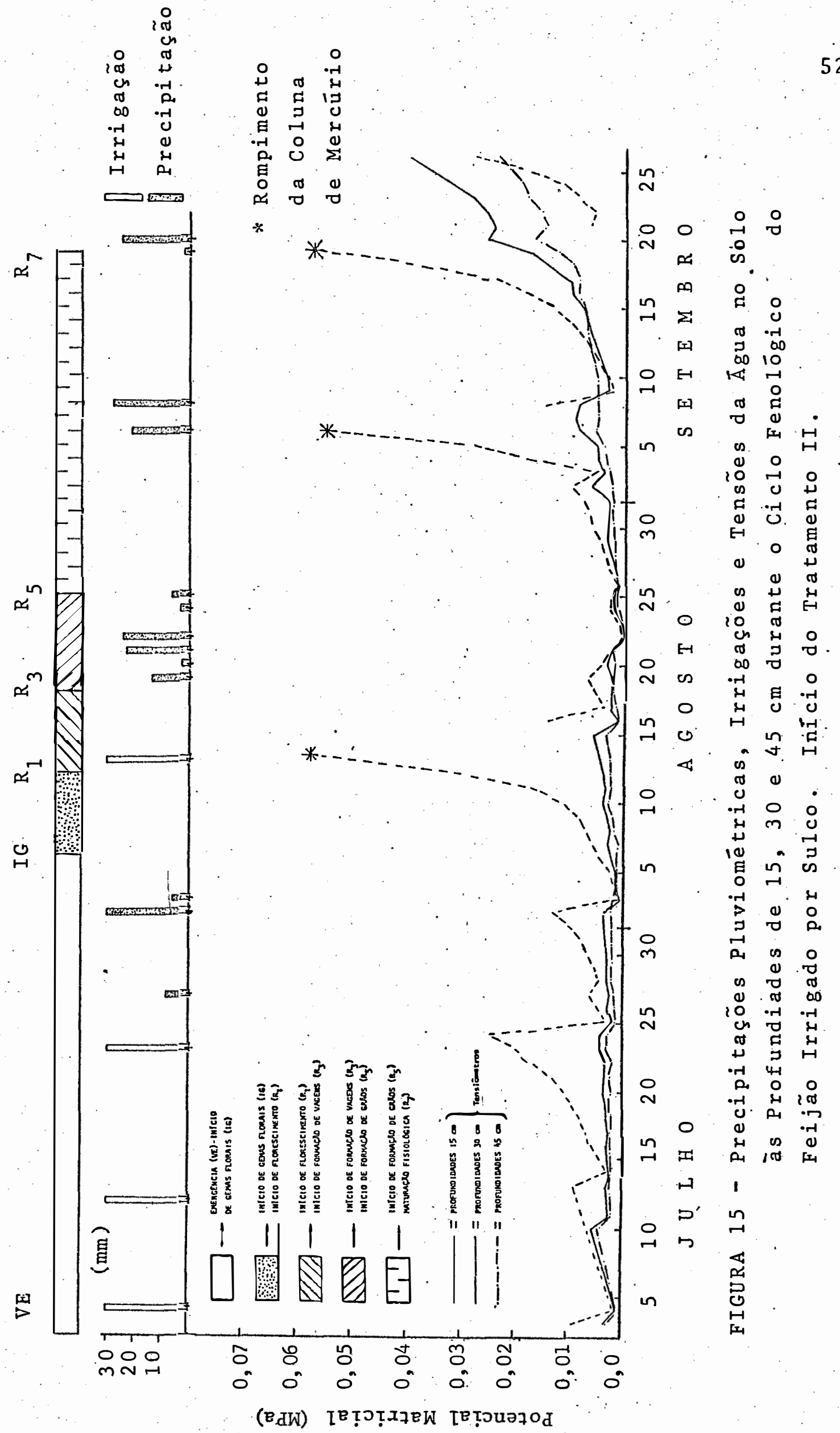




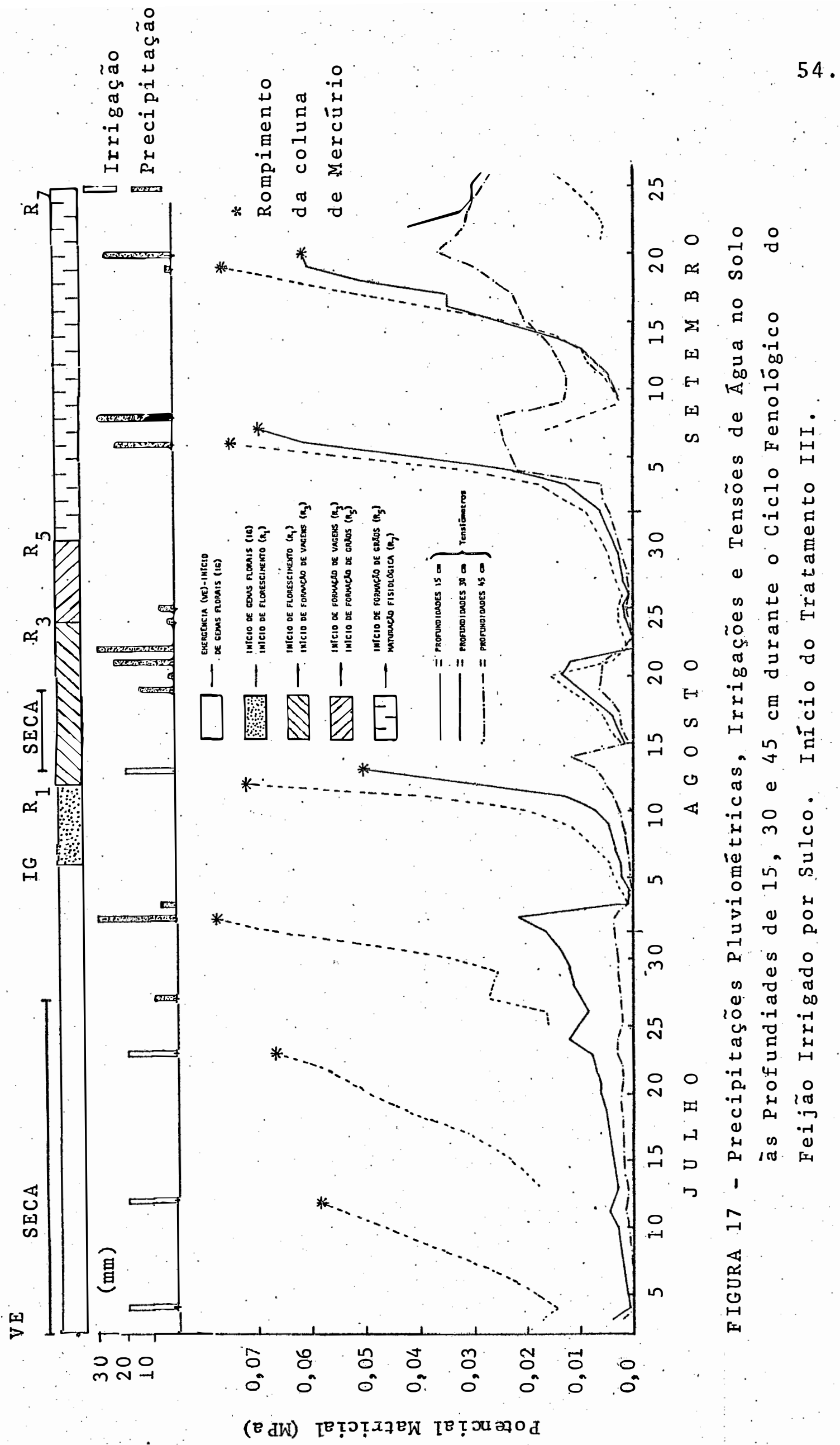




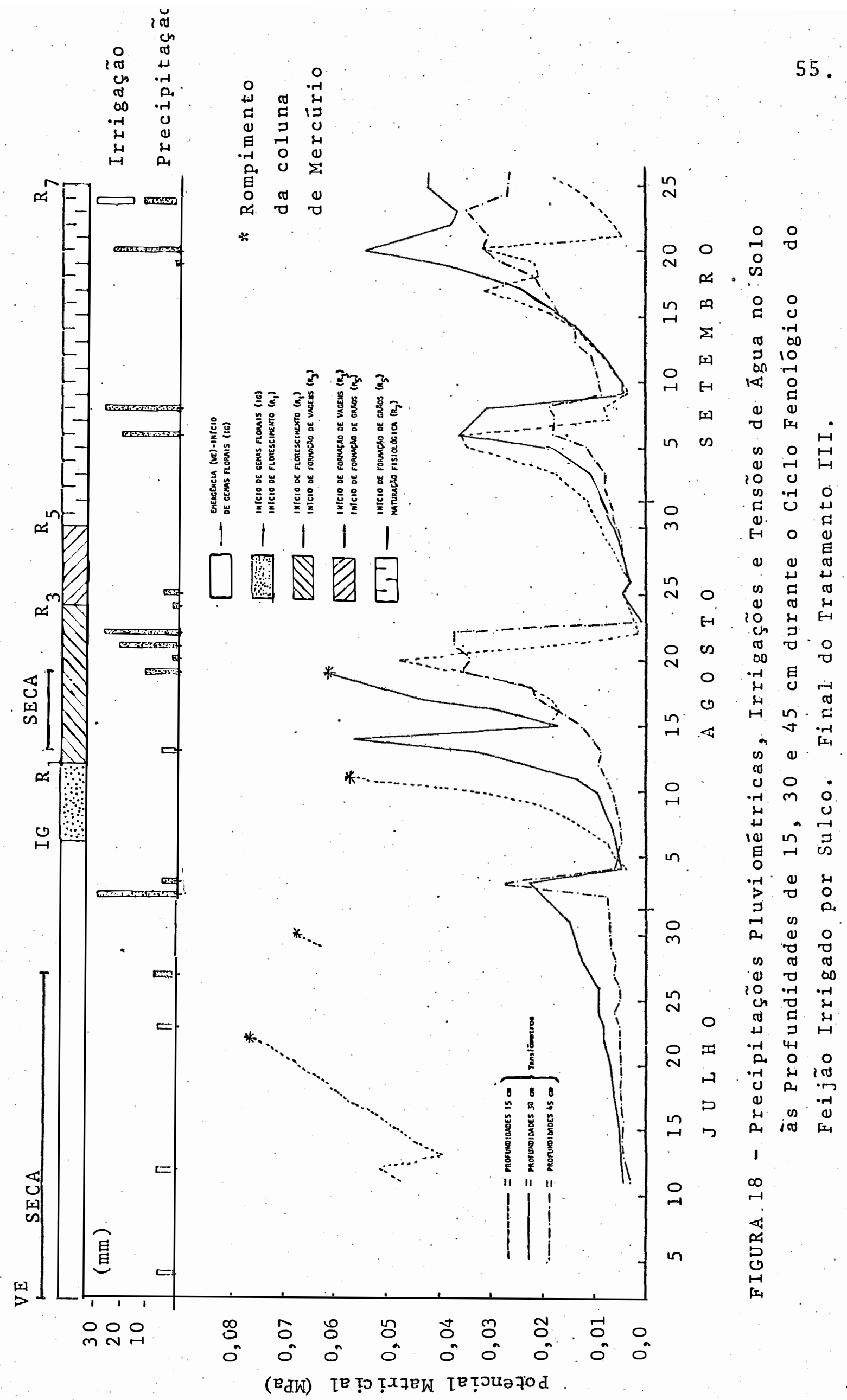




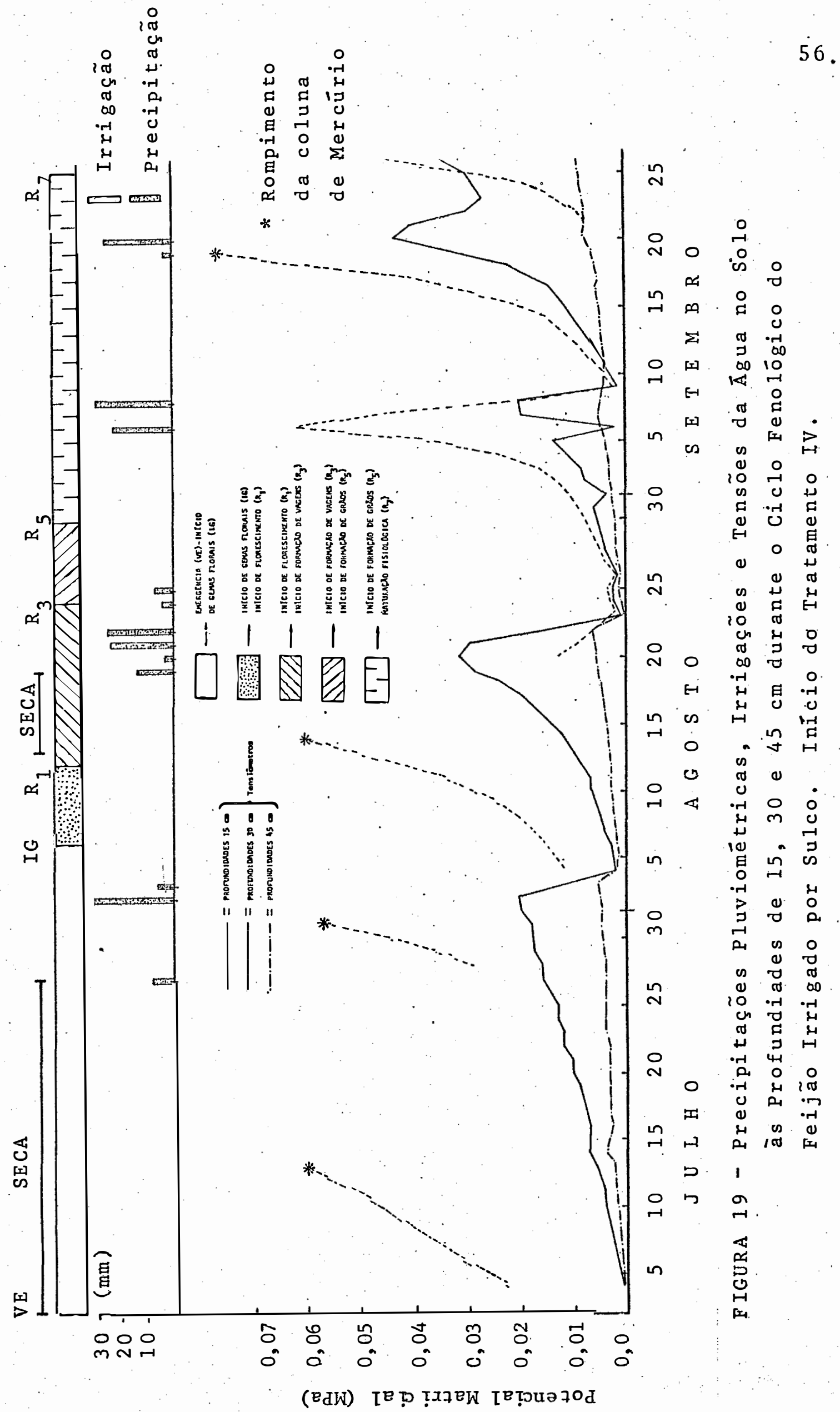




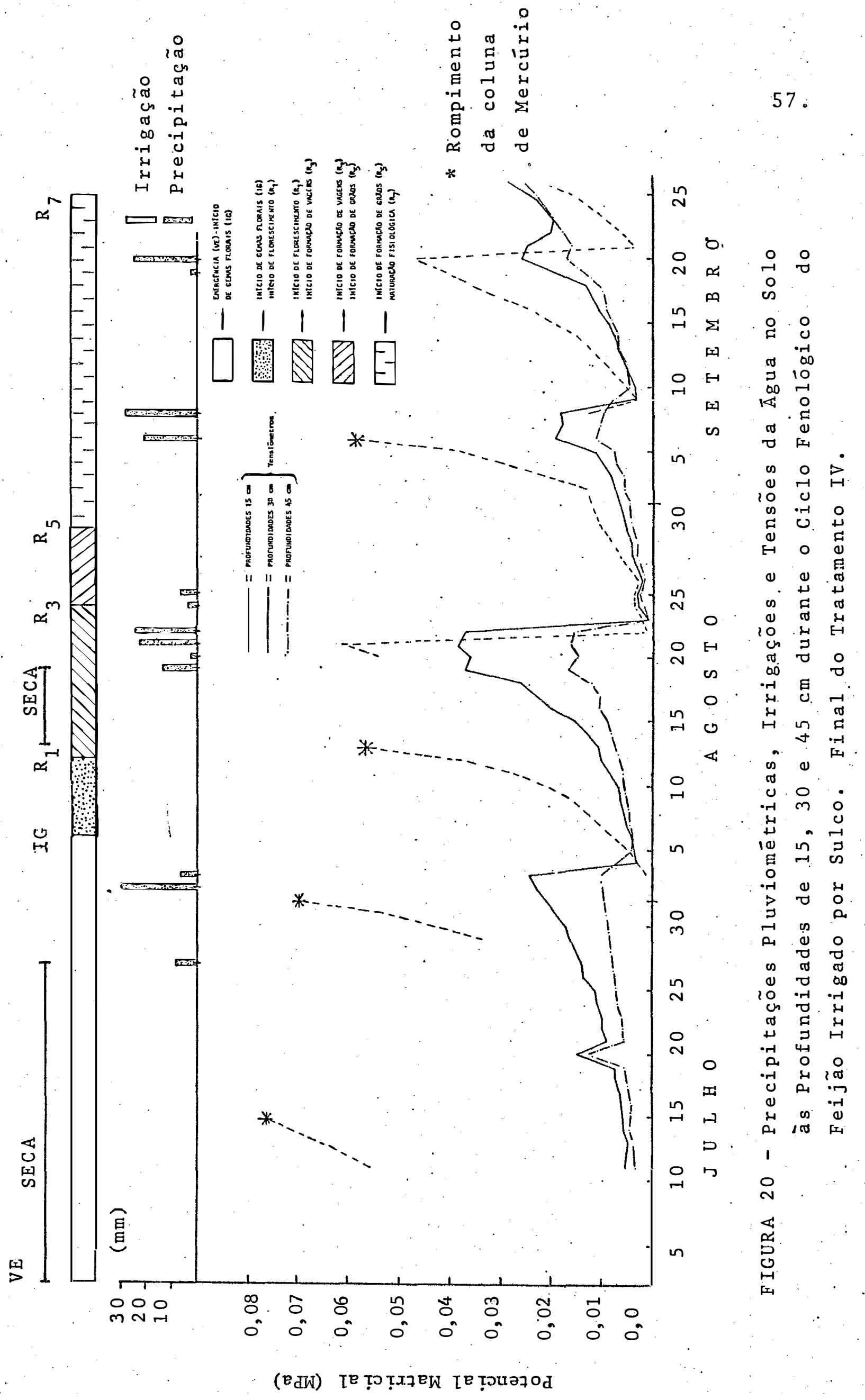


cio de florescimento e formação de vagens).

Foi observado nos tratamentos III e IV um atraso na maturação fisiológica de 8 dias e também houve atraso na formação de vagens com relação aos tratamentos I e II. Isto parece estar de acordo com Mac Master et alii (1965), cittados por SALTER e GOODE (1967), que observaram maturidade das plantas mais cedo nos tratamentos que receberam umidade ade quada do plantio ao florescimento, do que os tratamentos que receberam mẹnor nưmero de irrigações. Fato também observado por BERGAMASCHI (1984) no tratamento onde a deficiência de água ocorreu durante a formação dos botões florais e a floração. Observou-se ainda que, nos tratamentos III e IV, as vagens entraram em senescência e abscisão, ainda que rudimentares.

No final do 29 período seco e início das precipitações pluviométricas nos tratamentos. III e IV verjficou-se nova emissão de flores, provavelmente de gemas secundārias, e a maturação fisiológica não ficou bem caracterizada pelo fato de ter ocorrida intensa retenção foliar.

Segundo KEMP et alii (1974), citando vários autores, a abscisão de vagens, má formação de grãos e rendimentos reduzidos, estão associados com altas temperaturas e estresse hídrico durante a floração e o desenvolvimento de. grãos, condição esta verificada para os tratamento III e IV. Jâ ROBINS e DOMINGO (1956) constataram que, quando o estresse hídrico ocorre durante a floração, as plantas do feijoeiro se desenvolvem mais rapidamente. Por outro la do, DUBETz e MAHALlE (1969), observaram que déficit hídrico na 
pré-floração e floração retardou a colheitá de feijão em uma semana, em relação ạs plantas com déficit hîdrico em pós-flora çao.

Também KRETCHMER et alii. (1980 observaram retardamento na maturaçạo fisiológica do feijoeiro em condições de solo seco, com boa recuperação de rendimento de grãos uma vez suspenso o estresse.

Nas Figuras 13 a 20 estão representadas as pre cipitações, irrigações e tensões da água no solo, às profundidades de 15,30 e $45 \mathrm{~cm}$, durante o ciclo fenológico do feijoe $\underline{i}$ ro irrigado por sulcos.

Nas Figuras 13; 14, 15 e 16, que correspondem ao início e final de sulco dos tratamentos I e II, respectivamente, observa-se que a cultura esteve a maior parte do seu c $\underline{i}$ clo sob tensões inferiores a $0,08 \mathrm{MPa}$, sob tensões maiores que esta isto se deu no mâximo por 2 dias, quando então ocorreu uma chuva ou efetuou-se uma irrigação. Observa-se tambẻm uma variação das leituras tensiométricas somente. no tensiômetro instalado a $15 \mathrm{~cm}$ de profundidade, ao passo que no localizado a. $30 \mathrm{~cm}$ de profundidade observou-se variação somente quando a cultura estava no estảdio de formação de grãos, excessão feita ao final do sulco no Tratamento II.

Nas Figuras $17,18,19$ e 20 , observa-se que a cultura nos tratamentos III e IV ficou submetida durante quase todo o ciclo a tensões superiores a 0,08 MPa, mesmo para o in $\underline{i}$ cio do sulco no tratamento III, que recebeu através de irriga- 
ções uma lâmina ao redor de $20 \mathrm{~mm}$. Fato este explicado por se tratar de tratamento com vazão menor e consequentemente períme tro molhado menor, encontrando assim o sistema radicular das plantas dificuldade em atingir o bulbo úmido.

\subsection{Anālise de Crescimento}

Nas Figuras 21 e 22 estão representadas as cur vas de peso da matéria seca da parte aérea, indice de ärea foliar (IAF) ao longo do ciclo do feijoeiro, nos respectivos tra tamentos e posições no sulco.

Ao analisar os resultados de acúmulo de matéria seca e de Indice de. Area Foliar (IAF) correspondentes aos diferentes tratamentos, constata-se que ocorreram diferenças significativas entre os tratamentos irrigados e não irrigado, o que está de acordo com o princípio de que a produção de maté ria seca de uma comunidade de plantas é função da sua fotossin tese líquida que, por sua vez, depende da áréa foliar, como su gerem KUENEMANN et alii (1979).

Observa-se ainda na posição final dos sulcos dos diferentes tratamentos, gradientes decrescentes de IAF e de matéria seca acumulada, fato ésperado, uma vez que os tratamen tos nesta posição receberam lâminas decrescentes do I ao IV tratamento. Os efeitos sobre a formação de ārea foliar podem ser atribuídos a uma menor expansão dos folíolos, como também, pela abscisão das folhas inferiores (mais velhas) que foi ob- 


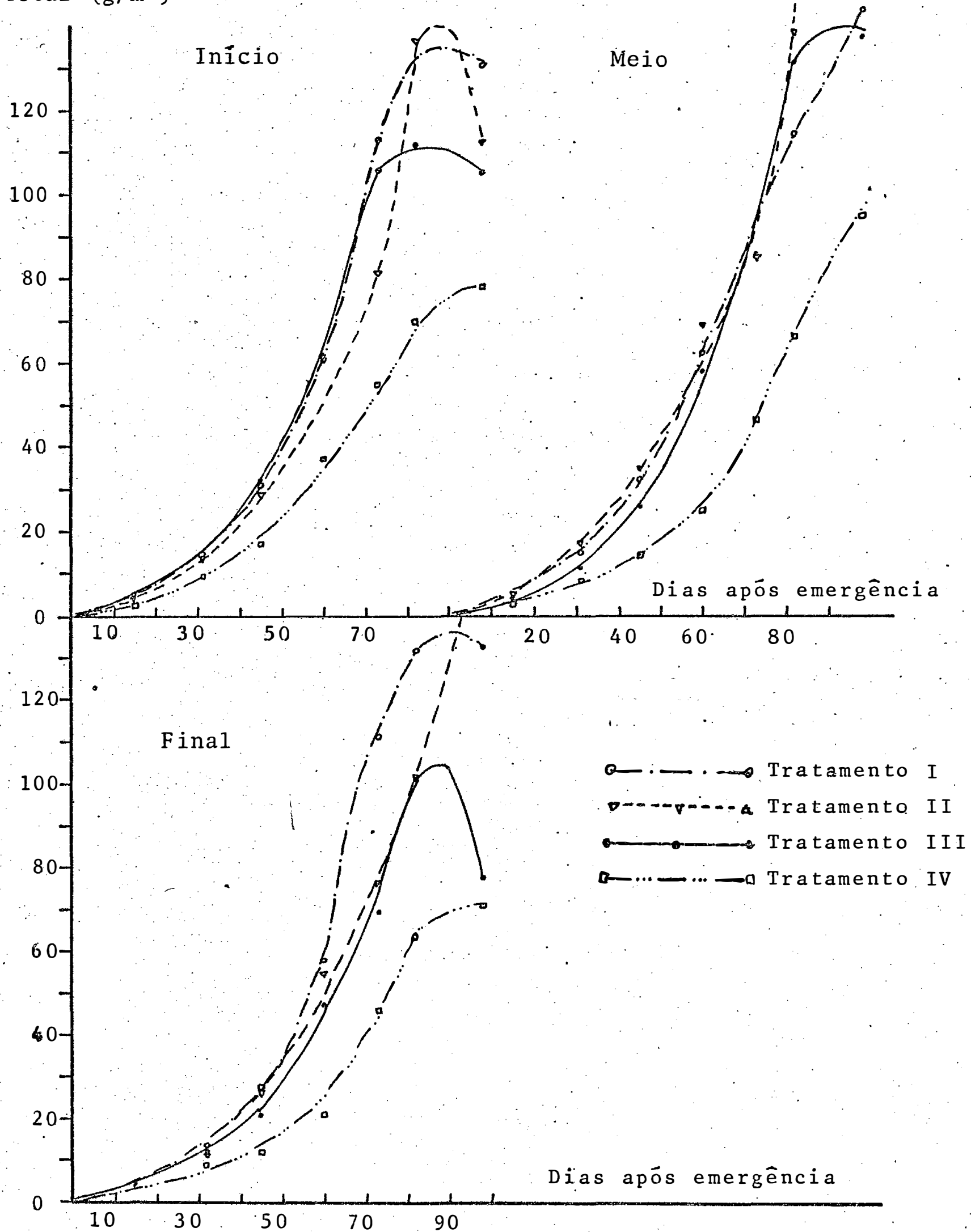

FIGURA 21 - Peso da Matéria Seca da Parte Aérea ao Longo do Ciclo do Fei joeiro Cultivar Aroana 80, sob 4 Tratamentos de Irrigação por Sulco, nas Posições Início, Meio e Final de Sulco. 


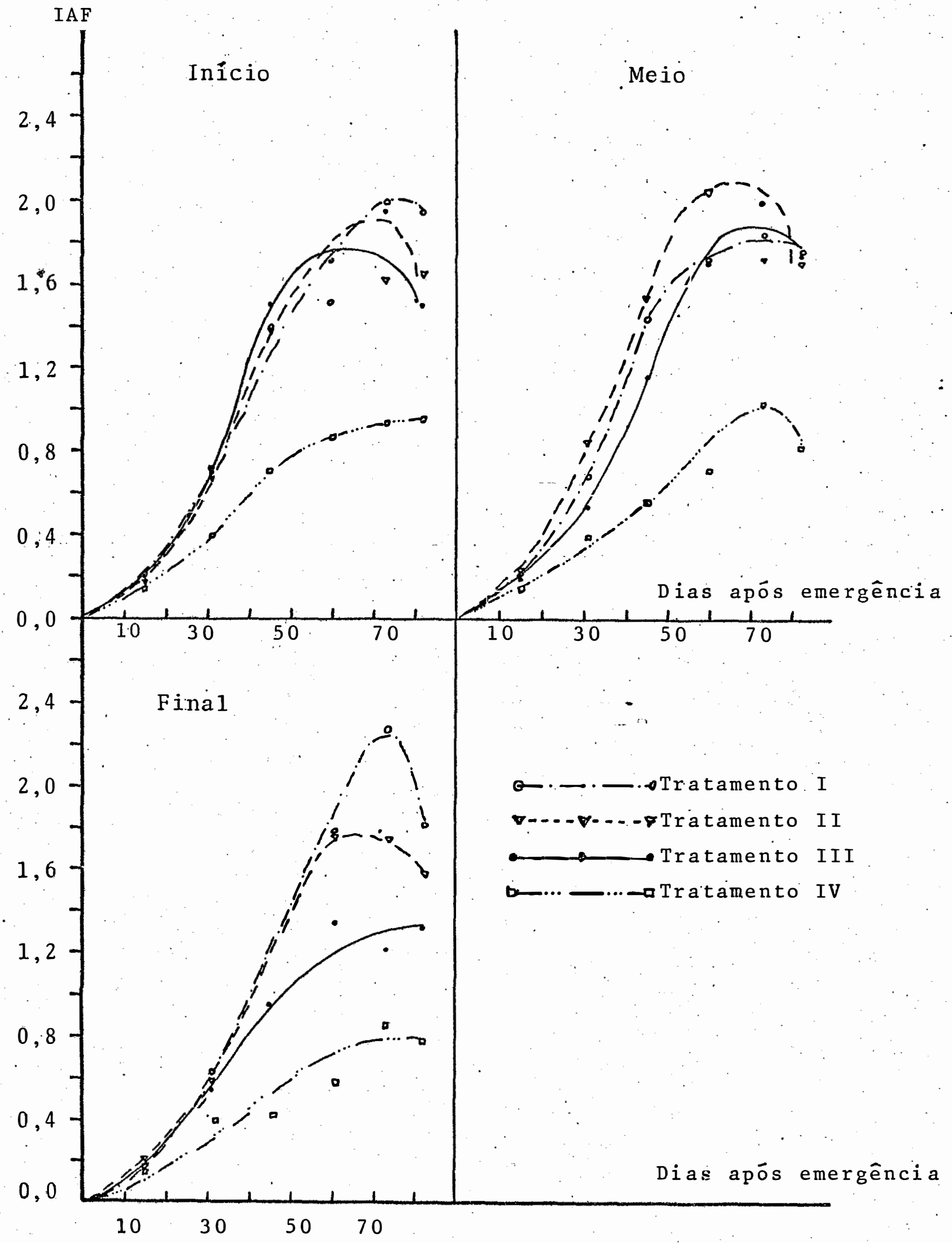

FIGURA 22 - Indice de Area Foliar (IAF) ao Longo do Ciclo do Fei joeiro Cultivar Aroana 80; sob 4 Tratamentos de Irrigação por Sulco, nas Posições Início, Meio e Final de Sulco. 
63.

servada no campo. RITCHIE (1981) ainda. considera que alẻm de afetar a expansao foliar, a deficiência hídrica do solo pode causar o enrolamento, morte parcial das folhas, diminuição de brotação, de polinização, de translocação e de enchimento de grãos.

Movimentos de paraheliotropismo foram bastante evidentes nas plantas sujeitas à deficiência hïdrica. Este mo:vimento, no sentido de orientar as folhas mais ou menos paralelamente à incidência de radiação solar, tem sido observado em feijoeiro (DUBETZZ, 1969 ; LAWN, 1982 a, LAWN, 1982 b).

Outra observação foi a mudança da coloração dos foliolos, de verde claro para verde escuro, em resposta à deficiência de água no solo e à alta evapotranspiração. Este processo foi considerado por ROBINS e DOMINGO (1956) como sintoma de déficit hỉdrico nas folhas e indicativo da necessidade de irrigação.

Após as ocorrências das chuvas, em intensidade igual ou superior a das irrigações, as plantas dos tratamentos III e IV apresentaram sintomas de deficiências hídricas bem antes das plantas dos tratamentos I e II. Nesse $\because$ aspecto, ROBINS e DOMINGO (1956) observaram nas folhas de plantas em inícìo de floração, sintomas visuais de estresse quando o solo se apresentava com falta de água nos primeiros $33 \mathrm{~cm}$, $\therefore$ sendo que em plantas jả florescidas, tal deficiência só foi observada para profundidades maiores; a isto os autores atribuíram di ferenças na extensão do sistema racidular. 
64.

4.6. Parâmetros de Rendimento

Os dados dos parâmetros de rendimento: produtí vidade de grãos, número de vagens por planta, número de grãos por vagem, número de nós por planta, número de ramificações por planta, comprimento de caule, matêria seca total da parte aérea por 10 plantas, foram submetidos a análise estatística em blo- . cos casualizados com sub-parcelas em classificação hierárquica, sendo verificada uma diferença significativa entre os tratamentos, para todos os parâmetros, excessão feita a número de nós por planta.

A análise estatística dos parâmetros de rendimento relativo às posições início, meio e final de sulço, dentro dos tratamentos, não revelou diferença significativa, apesar de notar-se, um gradiente decrescente do início para o final do sulco e um ligeiro crescimento do início para o meio do sulco, com queda para a posição final, mesmo para os tratamentos I e IV. Isto leva a supor uma mancha de solo na área central com melhores condições físicas e químicas que as extremida des.

4.6.1. Produtividade de Graõs

Comparando-se as médias das produtividades de grãos da Tabela 8, observa-se que em relação à testemunha nã̃o irrigada, os tratamentos I, II e III tiveram um aumento de pro- 
dução de $70,1,65,4$ e $34,6 \%$, respectivamente. As baixas produtividades de grãos dos tratamentos III e IV ficam bem caracterizadas pelo estresse hîdrico sofrido pelas plantas nos períodos de pré-florescimento e florescimento; fato evidenciado por vârios pesquisadores como KATTAN e FLEMING (1956), EL NADI (1970), RAGGI et a1ii (1972, MAGALHAES e MILLAR (1978), GUNTON e EVENSON (1980), SILVEIRA et alii. (1981) e SAWAZAKI et alii. (1981) .

TABELA 8 - Valores Referentes à Produtividade Média de Grãos em $\mathrm{kg} / \mathrm{ha}$, para os Diferentes Tratamentos no Início, Meio e Final de Sulco.

\begin{tabular}{rrrrrr}
\hline \multicolumn{1}{l}{ TRATAMENTO } & INICIO & MEIO & FINAL & MEDIA \\
\hline I & 1548,9 & 1522,8 & 1307,8 & 1459,8 & A \\
II & 1384,8 & 1562,7 & 1312,3 & 1419,9 & A \\
III & 1144,2 & 1268,0 & 1054,1 & 1155,4 & AB \\
IV & 905,1 & 921,6 & 747,8 & 858,2 & B \\
\hline
\end{tabular}

d.m.s. para tratamentos (Tukey $1 \%$ ) $=356,6$

d.m.s. para posiçōes dentro dós tratamentos (Tukey $5 \%$ ) $=480,3$ Obs. As médias seguidas da mesma letra não diferem estatistica mente entre si. 
Pela anāilise estatística das produtividades de grãos apresentada ná Tabela 9, pode-se verificar que o efeito dos tratamentos sobre a produtividade, foi altamente significa tivo ao nível de $1 \%$ de probabilidade. O efeito da interação tratamento $x$ posição no sulco não foì significativo.

Comparando-se as médias de produtividade de grãos, observa-se que o maior rendimento ocorreu no tratamento I e o menor no tratameto IV. As médias referentes aos tratamen tos I e II diferiram estatisticamente do tratamento IV.

Outro fato observado é que as plantas dos trat. tamentos ou posições que acusavam défict hỉdrico no estádio de florescimento, mesmo recebendo água das chuvas ainda neste estádio, apresentaram baixos rendimentos, STOCKER (1974) verificou o mesmo para os estádios de pré-florescimento e florescimento.

4.6.2. Nümero de Vagens por Planta

Na Tabela 10 são mostrados os valores médios referentes ao número de vagens por planta obtidos nas posições início, meio e final do sulco, nos diferentes tratamentos. 
TABELA 9 - Análise Estatîstica em Blocos Casualizados com SubParcelas em Classificação Hierärquica para Produtivi dade de Grãos sob Diferentes Tratamentos de Irrigação por sulco.

\begin{tabular}{lrrrr}
\hline C. de Variação & G L & S Q & Q M & F \\
\hline Blocos & 4 & 2581288.7529 & 645322.1882 & \\
Tratamentos (T) & 3 & 3488085.9394 & 1162695.3134 & $10.750^{* *}$ \\
Resíduos & 12 & 1297863.5634 & 108155.2969 \\
& & & & \\
& & 19 & 7367238.2558 &
\end{tabular}

Posições do Tratamento $1 \quad 2 \quad \cdots \quad 175054.5783 \quad 87527.2891 \quad 0.910$

Posições do Tratamento $2 \quad 2 \quad \begin{array}{lllll}2 & 166051.0626 & 83025.5313 & 0.863\end{array}$

Posições do Tratamento $3 \quad 2 \quad \begin{array}{lllll} & 2 & 115376.7656 & 57688.3828 & 0.600\end{array}$

Posições do Tratamento $4 \quad 2$. $91992.2813 \quad 45996.1406 \quad 0.478$

Residuos (B) $\quad \begin{array}{llll}32 & 3075915.6269 & 96122.3633\end{array}$

$\begin{array}{lll}\text { T O T A L } & 59 & 10991628.4453\end{array}$
C.V. para Parcelas
26.882
C.V. para Sub-Parcelas
25.343

** Significativo a 1.0 de probabilidade 
TABELA 10 - Nümero Médio de Vagens por Planta obtido no Início, Meio e Final do Sulco para Diferentes Tratamentos.

\begin{tabular}{rrrrrrr}
\hline TRATAMENTO & INICIO & $\ldots$ & ME.IO & $\ldots$ & FINAL & MED IA \\
\hline I & 11,5 & 12,5 & 12,6 & 12,2 & A \\
II & 14,5 & 13,6 & 10,1 & 12,7 & A \\
III & 9,6 & 12,5 & & 7,7 & 9,5 AB \\
IV & 7,7 & 10,3 & 7,4 & 8,5 & B \\
\hline
\end{tabular}

d.m.s. para tratamentos (Tukey $5 \%$ ) $=3,5$

d.m.s. para posições dentro dos tratamentos (Tukey $5 \%$ ) $=4,6$ Obs. As médias seguidas da mesma letra não diferem estatistica mente entre si.

Pela anâlise estatística do número de vagens por planta (Tabela 11), pode-se verificar que o efeito dos tratamentos foi significativo ao nível de $5 \%$ de probabilidade. 0 efeito da interação tratamento $x$ posição no sulco foi significativo ao nível de 5 ono tratamento III. Comparando-se as médias de cada tratamento, observa-se, maior número de vagens por planta no tratamento II e menor no tratamento IV.

As médias referentes aos tratamentos I e II di feriram estatisticamente do tratamento IV, houve também diferença estatística entre as médias das posições meio e final do sulco, no tratamento III. 
TABELA 11 - Anālise Estatística em Blocos Casualizádos com SubParcelas em Classificação Hierạarquica para Número de. Vagens por Planta sob Diferentes Tratamentos de Irrigação por Sulco.

\begin{tabular}{lcccc}
\hline C. de Variação & G L & S Q & Q M & F \\
\hline Blocos & 4 & 188.4341 & 47.1085 \\
Tratamentos (T) & 3 & 178.7646 & 59.5882 & $5.785^{*}$ \\
Resíduos & 12 & 123.6045 & 10.3003 &. \\
\hline
\end{tabular}

Parcela

$19 \quad \cdot 490.8032$

Posiçõ do Tratamento 1 .

$\begin{array}{lrrrrrr}\text { Posições do Tratamento } & 2 & 2 & 5.3 .3320 & 26.6660 & 3.001 \\ \text { Posições do Tratamento } & 3 & 2 & 57.4120 & 28.7060 & 3.231 \\ \text { Posições do Tratamento } 4 & 2 & 24.9173 & 12.4586 & 1.402 \\ \text { Residuos (B) } & 32 & 284.2612 & 8.8831 & \end{array}$

T O T A L

$5.9 \quad 914.4099$
C.V. para Parcelas.
29.575
C.V. para Sub-Parcelas
27.465

* Significativo a $5 \%$ de probabilidade 
Diversos pesquisadores observaram esse efeito de estresse hỉdrico principalmente quando o déficit de água ocorreu durante a fase de florescimento, onde a exigência', de água pela planta é maior. Assim, uma redução no balanço interno da água na planta, no periodo reprodutivo, tem influência direta na'redução de vagens por planta, conformë observações de ROBINS e DOMINGO (1956), BERNARDO (1970), EL NADI (1970), MAGALHÃES (1978), BURMAN (1961), RESENDE (1979) e MIRANDA . et alii (1977).

De acordo com DLBETZ e MAHALLE (1969), os efeitos diretos do estresse hídrico no estágio de crescimento inte ragem para influenciar a quantidade de pegamento das flores e o desenvolvimento das vagens.

4.6.3. Número de Grãos por Vagens .

Na Tabela 12 são: mostrados os valores médi os referentes ao número de grãos por vagem obtidos nas positções início, meio e final de sulco, nos diferentes tratamentos. 
TABELA 12 - Número Médio de Grãos por Vagem obtidos no Início, Meio e Final do Sulco nos Diferentes Trata mentos.

\begin{tabular}{rrrrrr}
\hline TRATAMENTO & INICIO & MEIO & FINAL & MEDIA \\
\hline I & 4,2 & 4,5 & 4,0 & 4,3 & A \\
I I & 4,4 & 4,3 & 4,3 & 4,3 & A \\
II I & 4,3 & 4,2 & 3,8 & 4,1 & AB \\
IV & 3,8 & 3,4 & 3,7 & 3,6 & B \\
\hline
\end{tabular}

d.m.s. para tratamentos (Tukey $1 \%$ ) $=\cdot 0,50$

d.m.s. para posições dentro dos tratamentos (Ṭukey $5_{0}^{\circ}$ ) $=0,6$

Obs. As médias seguidas da mesma letra não diferem estatistica mente entre si.

Pela análise estatística do número de grãos por vagem (Tabela 13), pode-se verificar que o efeito dos tratamentos foi altamente significativo ao nivel de $1 \%$ de probabilidade. 0 efeito da interação tratamento $x$ posição no sulco não foi significativo.

Comparando-se as médias, observa-se maior núme ro de grãos por vagem nos tratamentos I e II e menor no tratamento IV. As médias referentes aos tratamentos I e II diferiram estatisticamente da do tratamento IV. 
TABELA 13 - Análise Estatística em Blocos Casualizados com SubParcelas em Classificaçã் Hierárquica para Número de Grãos por Vagem sob Diferentes Tratamentos. de Irrigação por Sulco.

\begin{tabular}{|c|c|c|c|c|}
\hline C. de Variação & G L & $S Q$ & Q M & $\mathrm{F}$ \\
\hline Blocos & 4 & 1.7473 & 0.4368 & \\
\hline Tratamentos (T) & 3 & 3.8100 & 1.2700 & $6.087 * *$ \\
\hline Resíduos & 12 & 2.5033 & 0.2086 & \\
\hline Parcela & 19 & 8.0606 & & \\
\hline Posições do Tratamento 1 & 2 & 0.4013 & 0.2006 & 1.590 \\
\hline Posições do Tratamento 2 & 2 & 0.0853 & 0.0426 & 0.338 \\
\hline Posições do Tratanento 3 & 2 & 0.4973 & 0.2486 & 1.970 \\
\hline Posições do Tratamento 4 & 2 & 0.4120 & 0.2060 & 1.632 \\
\hline Residuos (B) & 32 & 4.0373 & 0.1261 & \\
\hline $\mathrm{T} O \mathrm{~T} A \mathrm{~A}$ & 59 & 13.4940 & & \\
\hline
\end{tabular}
C.V. para Parcelas
11.167
C.C. para Sub-Parcelas
8.684

* * Significativo a $1 \%$ de probabilidade 
Esses resultados estão de acordo com o de outros pesquisadores, como STOCKER (1974) e MAGALHAES (1978), que observaram uma redução no número de grãos por vagem em função da pouca disponibilidade de âgua no solo.

4.6.4. Nủmero de Nôs por Planta

Na Tabela 14 são mostrados os valores méd $\underline{i}$ os referentes ao número de nós por planta obtidos nas posições início, meio e final de sulco, nos diferentes tratamentos.

TABEḶA 14 - Número Mẻdio de Nós por Planta obtido no Inỉcio, Meio e Final do Sulco, nos Diferentes Tratamentos.

\begin{tabular}{ccccc}
\hline TRATAMENTO & INICIO & MEIO & FINAL & MEDIA \\
\hline I & 9,5 & 9,6 & 9,4 & 9,5 A \\
II & 10,0 & 9,9 & 9,3 & 9,7 A \\
III & 9,4 & 9,7 & 9,3 & 9,5 A \\
IV & 8,8 & 9,2 & 9,0 & 9,0 A \\
& & & \\
d.m.s. para tratamentos (Tukey $5 \%$ ) & 0,8 \\
d.m.s. para posições dentro dos tratamentos (Tukey $5 \%$ ) 0,9 \\
Obs. As médias seguidas da mesma 1etra não diferem estatistica \\
mente entre si.
\end{tabular}


Pela anâlise estatỉstica do nümeró de nós por planta (Tabela 15), pode-se verificar que não foram significativos o efeito dos tratamentos e a interação tratamento $x$ posi ção.

Comparando-se as médias observa-se que o maior número de nôs por plantá foi observado no tratamento II e o menor no tratamento IV.

4.6.5. Número de Ramificações por Planta

Na Tábela 16 são mostrados os valores médios referentes ao número de ramificações por planta obtidos nas. posições início, meio e final de sulco nos diferentes tratamen tos.

Pela análise estatistica do número de ramifica ções por planta Tabela 17, pode-se verificar que o efeito de tratamento foi significativo ao nivel de 5\% de probabilidade. 0 efeito de interação tratamento $x$ posição nó sulco não foi significativo.

Comparando-se as mêdias observa-se maior número de ramificações por plantas nos tratamentos I, II e III, que diferem estatisticamente do tratamento IV: 
TABELA 15 - Anālise Estatística em Blocos Casualizados com SubParcelas em Classificação Hierárquica para Número de. Nós por Planta sob Diferentes Tratamentos de Irrigação por Sulco.

\begin{tabular}{lrrrr}
\hline C. de Variação & G L & S Q & Q M & F \\
\hline Blocos & 4 & 5.8493 & 1.4623 & \\
Tratamentos (T) & 3 & 4.5820 & 1.5273 & 2.583 \\
Residuos & 12 & 7.0946 & 0.5912 &
\end{tabular}

Parcela $\quad 19 \quad 17.5260$

$\begin{array}{llllll}\text { Posições do Tratamento } 1 & 2 & 0.0813 & 0.0406 & 0.134 \\ \text { Posições do Tratamento } 2 & 2 & 1.5453 & 0.7726 & 2.560 \\ \text { Posições do Tratamento } 3 & 2 & 0.5493 & 0.2746 & 0.910 \\ \text { Posições do Tratamento } 4 & 2 & 0.5813 & 0.2906 & 0.963 \\ \text { Residuos (B) } & 32 & 9.6559 & 0.3017 & \end{array}$

$\begin{array}{lll}\text { T } O \text { T A L } & 59 & 29.9393\end{array}$
C.V. para Parcelas
8.148
C.V. para Sub-Parcelas
5.821 
TABELA 16 - Número Mêdio de Ramificações por Planta obtido no Início, Meio e Final do Sulco nos Diferentes Tratamentos.

\begin{tabular}{cccccc}
\hline TRATAMENTO & INICIO & MEIO & FINAL & MEDIA \\
\hline I & 3,6 & 3,5 & 3,5 & 3,5 A \\
II & 3,7 & 3,6 & 3,3 & 3,5 A \\
III & 3,5 & 3,9 & 3,3 & 3,6 & A \\
IV & 2,8 & 3,0 & 2,5 & 2,8 & B \\
\hline
\end{tabular}

d.m.s. para tratamento (Tukey. $\left.5 \frac{\circ}{0}\right)=0,7$

d.m.s. para posições de tratamento (Tukey $5_{0}^{\circ}$ ) $=0,8$

Obs. As médias seguidas da mesma letra não diferem estatistica mente entre si.

4.6.6. Comprimento do Caule (cm)

Na Tabela 18 são mostrados os valores médios referentes ao comprimento de caule obtidos nas posições início, meio e final de sulco, nos tratamentos.

Pela análise estatística do comprimento de caule (Tabela 19), pode-se verificar que o efeito de tratamentos foi significativo a nível de $1 \%$ de probabilidade. A interação tratamento x posição no sulco não foi significativa. 
TABELA 17 - Anâlise Estatística em Blocos Casualizados com SubParcelas em Classificação Hierârquica para Número de Ramificações por Planta sob Diferentes Tratamentos de Irrigação por Sulco.

\begin{tabular}{|c|c|c|c|c|}
\hline C. DE VARIAÇÃO & G L & $S Q$ & Q M & F \\
\hline Blocos & 4 & 10.5643 & 2.6410 & \\
\hline Tratamentos (T) & 3 & 7.0626 & $2 \because 3542$ & $5.216 *$ \\
\hline Residuos & 12 & 5.4156 & 0.4513 & \\
\hline Parce la & 19 & 23.0426 & & \\
\hline Posições do Tratamento 1 & 2 & 0.0119 & 0.0059 & 0.020 \\
\hline Posições do Tratamento 2 & 2 & 0.5320 & 0.2660 & 0.921 \\
\hline Posições do Tratamento 3 & 2 & 0.9373 & 0.4686 & 1.623 \\
\hline Posições do Tratamento & 2 & 0.6253 & 0.3126 & 1.082 \\
\hline Resỉduos (B) & 32 & 9.2399 & 0.2887 & \\
\hline --n--n-- & & & & \\
\hline $\mathrm{T} O \mathrm{TA} \mathrm{L}$ & 59 & 34.3893 & & \\
\hline
\end{tabular}

C.V. para Parcelas 20.073

C.V. para Sub-Parcelas 16.056

* Significativo a $5 \%$ de probabilidade 
TABELA 18 - Comprimento Médio de Caule (cm) obtido no Início, Meio e Final do Sulco nos Diferentes Tratamentos.

\begin{tabular}{|c|c|c|c|c|c|}
\hline TRATAMENTO. & INICIO & MEIO & FIINAL & MEDIA & \\
\hline I & 27,9 & 26,8 & 26,6 & 27,1 & A \\
\hline I I & $26, I$ & 28,4 & 23,6 & 26,0 & A \\
\hline I I I & 24,8 & 25,9 & 22,5 & 24,4 & A \\
\hline IV & 17,0 & 17,1 & 17,8 & 17,3 & B \\
\hline
\end{tabular}

d.m.s. para tratamentos (Tukey $1 \%$ ) $=6,2$

d.m.s. para posições dentro dos tratamentos (Tukey $5 \%$ ) $=6,3$

Obs. As médias seguidas da meșma letra não diferem estatistica. mente entre si.

Comparando-se as médias observa-se maior comprimento de caule no tratamento I e menor no tratamento IV. As médias referentes aos tratamentos I, II e III diferiram estatisticamente do tratamento IV.

Esses resultados estão de acordo com MAURER et alii (1969) que observaram plantas mais altas nos tratamentos onde houve irrigação no período de pré-florescimento.

Ressaltam ainda HSIAO et alii (1979) que a pri meira indicação de deficiência hídrica é a redução no tamanho da planta em comparação com aquelas cultivadas com ampla disponibilidade hídrica. 
TABELA 19 - Anālise Estatistica em Blocos Casualizados com SubParcelas em Classificação Hierárquica para Comprimento de; Caule sob Diferentes Tratamentos de Irriga ção por 'Sulco.

\begin{tabular}{lrrrr}
\hline C: de Variação & G & S & Q M & F \\
\hline Blocos & 4 & 245.4060 & 61.3515 & \\
Tratamentos (T) & 3 & 873.0385 & 291.0128 & $8.856^{* *}$ \\
Resiudos & 12 & 394.2887 & 32.8573 &
\end{tabular}

Parcela

$19 \quad 1512.7333$

Posições do Tratamento 1

Posições do Tratamento 2 . 2

Posições do Tratamento 32

$4.5626 \quad 2.2812 \quad 0.139$

Posições do Tratamento 4.2

$\begin{array}{llll}56.7546 & 28.3773 & 1.729\end{array}$

Residuos (B)

32 .

$29.3448 \cdot 14.6724 \quad 0.894$

1.7605

0.8802

0.053

524.9006

16.4031

T O T A L

$59 \quad 2130.0566$
C.V. para Parcelas
24.261
C.V. para Sub-Parcelas
17.142

* Significativo a $1 \%$ de probabilidade 
4.6.7. Matéria Seca Total da Parte Aérea em Gramas por 10 Plantas

Na Tabela 20 são.mostrados os valores médios, referentes a matéria seca da parte aérea em gramas por 10 plan tas, obtidos nas posições início, meio e final de sulco, nos diferentes tratamentos.

TABELA 20 - Matéria Seca Total da Parte Aérea em Gramas por 10. Plantas obtida no Início, Meio e Final de Sulco nos Diferentes Tratamentos.

\begin{tabular}{crrrrr}
\hline TRATAMENTO & INICIO & MEIO & FINAL & MEDIA \\
\hline I & 130,3 & 150,0 & 132,5 & 137,6 & $\mathrm{~A}$ \\
II & 158,1 & 156,7 & 112,0 & 142,3 & $\mathrm{~A}$ \\
III & 105,7 & 137,4 & 77,6 & 106,9 & $\mathrm{AB}$ \\
IV & 78,7 & 95,5 & 70,9 & 81,7 & $\mathrm{~B}$ \\
& & & & & \\
\hline
\end{tabular}

d.m.s. para tratamentos (Tukey $1 \%$ ) $=47,0$

d.m.s. para posições dentro dos tratamentos (Tukey $5 \%$ ) $=67,1$

Obs. As mëdias seguidas da mesma letra não diferem estatistica mente entre si. 
Pela análise Estatística da matéria seca total em gramas por 10 plantas (Tábela 21), pode-se verificar que o efeito de tratamentos foi significativo ao nível de $1 \%$ de probabilidade. A interação tratamento $x$ poșição no sulco não foi significativa.

Comparando-se as médias observa-se que o peso de matéria seca total da parte aérea em gramas por 10 plantas nos tratamentos I e II diferiram estatisticamente do peso do tratamento IV.

0 efeito do estresse hídrico acarreta uma redu ção na matéria seca total, traduzida por um decréscimo no índi ce de crescimento, cujos valores encontrados no presente traba tho, estão em concordância com os de diversos autores como KRAMER (1959; 1963), SLAYTER (1969), MILLAR (1972), HSIAO (1974) e BEGG e TURNER (1976).

A medida que decresce o teor de água no solo hã uma redução no potencial de água na folha. Em decorrência hã um decréscimo na abertura estomatal e uma eventual redução do indice de transpiração, sendo que, este efeito do fechamento dos estômatos acarreta maior redução no indice de crescimento do que no índice de transpiração MILLAR (1972).

0 alongamento celular é um dos processos que contribuem basicamente para o crescimento e desenvolvimento das plantas. A susceptibilidade das plantas a esse mecanismo foi claramente demonstrada por pesquisadores como BOYER (1970), HSIAO et aiii (1970) e ACEVEDO et alii (1971), citado por 
TABELA 21 - Anālise Estatística em Blocos Casualizados com SubParcelas em Classificação Hierārquica para Matẻria Seca Total da Parte Aẻrea por 10 Plantas sob Diferentes Tratamentos de Irrigação por Sulco.

\begin{tabular}{lrrrr}
\hline C. de Variação & G L & SQ & Q M & F \\
\hline Blocos & 4 & 35206.8101 & 8801.7025 \\
Tratamentos (T) & 3 & 36185.4531 & 12061.8177 & $6.421^{* *}$ \\
Resíduos & 12 & 22540.6562 & 1878.3880 \\
& & & & \\
\hline Parcela & 19 & 93932.9194 & \\
\end{tabular}

Posições do Tratamento 12

$1156.7124 \quad 578.35620 .308$

Posições do Tratamento 22

$6890.7175 \quad 3445.3587 \quad 1.838$

Posições do Tratamento 32

$8956.2201 \quad 4478.1100 \quad 2.390$

Posições do Tratamento 4.2

$1573.3296: 786.6648 \quad 0.419$

Residuos (B).

32

$59956.9429 \quad 1873.6544$

T. 0 T A L

59. $\quad 172466.8400$
C.V. para Parcelas
36.995
C.V. para Sub-Parcelas
36.948

** Significativo a $1 \%$ de probabilidade 
BEGG e TURNER (1976).

\subsection{Acréscimo de Produção Devido a Irrigação - Anālise Econômica}

Comparando as produções de grãos de 1459,8, 1419,9 e $1155,4 \mathrm{~kg} / \mathrm{ha}$ com as lâminas de água utilizadas nas . quatro irrigações de $215,08,133,2$ e 109,0 mm, observa-se que, para um acréscimo na produção de $601,6,561,7$ e $297,2 \mathrm{~kg} / \mathrm{ha}$ fo ram gastos $0,36,0,24$ e $0,37 \mathrm{~mm}$ de água por quilograma de feijão, respectivamente, quando comparados com a testemunha.

Embora o tratamento II tenha produzido um pouco menos que o tratamento I; 1419,9 e $1459,8 \mathrm{~kg} / \mathrm{ha}$, respectiva mente, gastou na condução da irrigação $38 \%$ menos de água.

Em decorrência deste fato, foi efetuada uma avaliação econômica superficial que, forneceu os resultados apresentados nas Tabelas 22 e 23.

Da análise das Tabelas verifica-se que embora

- tratamento II tenha consumido $38 \%$ menos de água em relação ao tratamento $I$, a receita 1 iquida desses tratamentos, pratica mente se equivalem, o que vem demonstrar que o preço da água tem peso pequeno em relação aos demais insumos, para as condições do experimento.

o tratamento II teria importância relevante se a cultura fosse conduzida em regiões semi-āridas, onde além do custo elevado hâ escassez de água, 
TABELA 22 - Custo da Produção do Feijão sem Coṇsiderar a da Irrigação.

\begin{tabular}{|c|c|c|c|c|}
\hline I $\quad \mathrm{T}, \mathrm{E}, \mathrm{M}$. & UNIDADE. & $\begin{array}{l}\text { QUANTIDADE } \\
\text { POR HA } \\
\end{array}$ & $\begin{array}{r}\text { PREÇO } \\
\text { UNI TARIO } \\
\end{array}$ & $\begin{array}{l}\text { VALOR } \\
\text { TOTAL } \\
\end{array}$ \\
\hline \multicolumn{5}{|l|}{ Insumos } \\
\hline Semente & $\mathrm{kg}$ & 55 & 2.13 .0 & 117.150 \\
\hline $\begin{array}{l}\text { SuIfato de } \\
\text { Amônia }\end{array}$ & $\mathrm{kg}$ & 100. & $\therefore 6.50$ & 55.000 \\
\hline $\begin{array}{l}\text { Superfosfato } \\
\text { Simples }\end{array}$ & $\mathrm{kg}$ & 400 & 430 & 172.800 \\
\hline Defensivos & $\mathrm{L}$ & 1. & 100.000 & 100.000 \\
\hline Sacos & Unid.' & 24. & 600 & 14.400 \\
\hline \multicolumn{5}{|l|}{$\begin{array}{l}\text { Preparo do So- } \\
\text { lo e Semeadura }\end{array}$} \\
\hline Aração. & $\mathrm{h} / \mathrm{TR}$ & 3.5 & 14.000 & 49.000 \\
\hline Gradagem & $\mathrm{h} / \mathrm{TR}$ & 2.5 & 14.000 & 35.000 \\
\hline $\begin{array}{l}\text { Semeadura e } \\
\text { Adųbação }\end{array}$ & $\mathrm{d} / \mathrm{h}$ & 5.0 & $10: 000$ & 50.000 \\
\hline \multicolumn{5}{|l|}{$\begin{array}{l}\text { Tratos } \\
\text { Cultura is }\end{array}$} \\
\hline $\begin{array}{l}\text { Cultivo } \\
\text { Manual }\end{array}$ & $\mathrm{d} / \mathrm{h}$ & $\cdot 5.0$ & 10.000 & 50.000 \\
\hline $\begin{array}{l}\text { Aplicaçao de } \\
\text { Defensivos }\end{array}$ & $\mathrm{d} / \mathrm{h}$ & 1.5 & 10.000 & 15.000 \\
\hline $\begin{array}{l}\text { Adubação de } \\
\text { Cobertura }\end{array}$ & $d / h$ & 0.5 & 10.000 & 5.000 \\
\hline \multicolumn{5}{|l|}{$\begin{array}{l}\text { Colheita } \\
\text { Beneficiamento }\end{array}$} \\
\hline Colhe i ta Manual & $\mathrm{d} / \mathrm{h}$ & 7. & 10.000 & 70.000 \\
\hline Secagem & $\mathrm{d} / \mathrm{h}$ & 1 & 10.000 & 10.000 \\
\hline Ba teção & h/Trilh. & 4 & 28.000 & 112.000 \\
\hline
\end{tabular}




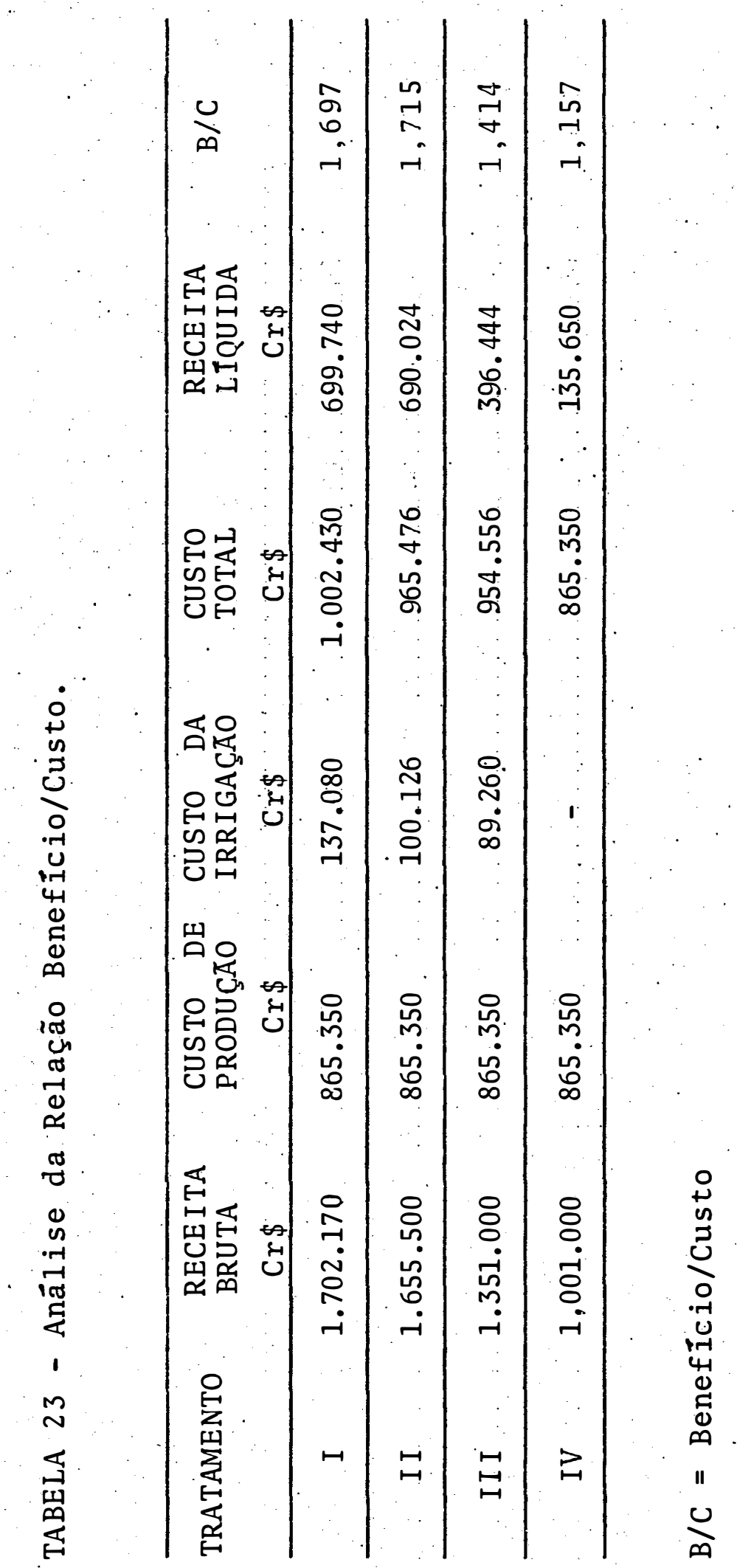


86.

5. CONCLUSOES

Os resultados obtidos suportam as $\therefore$ seguintes conclusões :

1) Em dois períodos secos na cultura do feijoeiro, de $26 / 06$ a $27 / 07$ (crescimento vegetativo) e de 12 a 19/08 (florescimento), relativos aos tratamentos menos irrigado e não irrigado, ocorreram reduções nos valores dos componen tes de rendimento como a produtividade, número de grãos por vagem, número de vagens por planta, número de ramificações por planta, comprimento de caule e matéria seca total da parte aérea por 10 plantas, o que não foi verificado para número de nós por planta. 
2) Os tratamentos de $0 \%$ da lâmina no final do sulco e não irrigado tiveram seu ciclo de desenvolvimento retardado em 8 dias, em relação aos tratamentos que receberam 50 e 100\% da lâmina no final do sulco, em virtude de chuvas poste riores aos períodos de déficit hídrico, ocorridas nos estádios de crescimento vegetativo e florescimento.

3) Nos tratamentos de 50 e $0 \%$ de lâmina útil no final do sulco, apesar da análise estatística não ter revelado diferenças significativas entre os parâmetros de cresci-. mento obtidos para os segmentos início, meio e final de sulco, nota-se um decréscimo dos seus valores, do início para o final. do sulco.

4) Devido a irrigação complementar, efetuada nos períodos de crescimento vegetativo e florescimento, houve um aumento de produtividade, em relação à testemunha, . de $601,6,561,7$ e $297,2 \mathrm{~kg} / \mathrm{ha}$, nos tratamentos com 100,50 e $0 \%$ da lâmina útil aplicada no final do sulco, com gastos de $0,36,0,24$ e 0,37 milímetros de lâmina de água por quilograma de f́eijão; respectivamente, para as condições dọ experimento. 
6. LITERATURA CITADA

AZEVEDO, H.M.; H.O. CARVALHO e A.A.MILlAR, 1975. Caracterização da Infiltração em Sulcos Abertos e Fechados. In: III

- Seminário Nacional de Irrigação e Drenagem, Fortaleza, (Resumo). $10 \mathrm{p}$.

BASCUR, B.G. e F.N. FRITSCH, 1975. Efeitos de Métodos y Frequência de Riego sobre Componentes de Rendimento en Frijol (Phaseolús vulgaris L.). Agricultura Técnica. Chile, 35 (3) : 147-152 .

BEGG, J.E. e N.C. TURNER, 1976. Crop Water Deficits. Advances in Agronomy. New York, 28: 161-217.

BERGAMASCHI, H., 1984. Perda de água e desenvolviimento do feijoeiro (Phaseolus vulgaris $L$.) sob efeito de diferentes condições de disponibilidade hídrica no solo e demanda evaporativa da atmosfera. Piracicaba, ESALQ/USP, 204p. (Tese de Doutoramento). 
BERNARDO, S.; J.D. GALVAO; H. GUERINI e J.B. de CARVALHO, 1970. Efeito de Níveis de Agua no Solo sobre a Produção do Feijoeiro (Phaseolus vulgaris, L.). Seiva.. Viçosa, 30: 7-13.

BERNARDO, S.; M. RESENDE e J.A. ARAOJO. 1977. Eficiência de Irrigação em Sulco com Redução da Vazão Inicial. Revista. Ceres. Viçosa, 24.(133): 261-277.

BERNARDO, S., 1978. Determinação da Perda D'água por Percolação e por "Runoff" em Irrigação por Sulco. Revista Ceres. Viçosa, 25 $(138): 169-178$.

BERNARDO, S. 1982. Manual de Irrigação. 2a ed. Viçosa, Imprensa Universitāria. $463 p$.

BURMAN, R.D. e D.W. BOHMONT, 1951. Evaluating the growth rate of great northern beans as influenced by soil moisture level under greenhouse conditions. Agronomy Journal. Madison, 53: $354-355$.

CAIXETA, T.J.; R. MARINATO e M.S. FRANÇA-DANTES, 1978. Efeito da Aplicação de Quatro Lâminas Totais de Agua e Três Níveis de Fertilizantes no Rendimento do Feijoeiro Comum (Phaseolus vulgaris, L.) I. EPAMIG, Projeto Feijão. Relatório $73 / 75$, Belo Horizonte. 
CHAMBERLAIN, A.R., 1952. Measuring Water in Smal1. Channels With W.S.C. Flume. Circular Washington, Agriculture Experi mental Station., Washington $\mathrm{n}: 200,9 \mathrm{p}$.

CRIDDLE, W.D.; S. DAVIS; C.H. PAIR e D.G. SHOCKELEY, 1956. Me thods for Evaluating Irrigation Systems. In: USDA Agriculture Handbook. 82: 03-10.

DASBERG, S. e J.W. BAKKER, 1970. Characterizing Soil Aeration Under Changing Soil Moisture Conditions for Bean Growth. Agronomy Journal. Madison, 62 (6): 689-692.

DUBETZ, S. e P.S. MAHALLE, 1969. Effect of Soil Water Stress on Bush Beans. Phaseolus vulgaris, L. at Three Stages of Growth. Journal of American. Society for Horticultural

. Science. Geneva, 49: 479-657.

DUBETZ, S.,.1969. An Unusual Photonastism Induced by Drough in Phaseolus vulgaris. Canadian Journal Botany. Ottawa, 47: $1640-1641$.

EL NADI, A.H., 1970. Water Relations of Beans. II. Effects of Differential Irrigation on Yield and Seed Size of Broad Beans. Experimental Agriculture. London, 6: 107-111. 
FEHR, W.R. "e C.E. CAVINESS, 1977. Stages of Soybeans Development. Ames, Iowa State University of Science and Technology. 11p. (Special Report, 80).

GABELMAN, W.H. e D.D. F. WILLIANS, 1960. Developmental Studies with Irrigated Snap Beans. Wisconsin, 57p. (Research Bulletin no 221).

GARRIDO, M.A.T. e H.A. TEIXEIRA, 1978a. Efeito de Diferente $\dot{\mathrm{s}}$ Niveis de Umidade do Solo sobre o Rendimento do Feijoeiro Comun na Região Sul de Minas Gerais. EPAMIG, Projeto Feijão, Relatório 75/76; Belo Horizonte.

GARRIDO, M.A.T. e H.A. TEIXEIRA, 1978b. Efeito de Diferentes Níveis de Umidade do Solo sobre o Rendimento do Feijoeiro Comum na Região Sul de Minas Gerais. EPAMIG, Projeto Feijão, Relatório 76/77, Belo Horizonte.

GARRIDO, M.A.T.; J.R.C. PURCINO e C.A.S. LIMA, 1979a. Efeito do Déficit de Água em Alguns Períodos de Ciclos de Crescimento sobre o Rendimento do Feijoeiro Comum. EPAMIG, Projeto Feijão, Relatório 77/78, Belo Horizonte.

GODOY, O.P.; J.T.M. ABRAHÃO; C. GODOY Jr.; R. GODOY e A. PETTA, 1966. A Irrigação do Feijoeiro (Phaseolus vulgaris L.). Revista de Agricultura. Piracicaba, 41(4): 145-153.

GRAY, M.D. e C.E. BEER, 1957. Factors Affeting Section of Proper "length-of run" as Applied to Furrow Irrigation Design. Iowa Agric. Exp. Sta., 8p. 
GUNTON, J.L. e J.P. EVENSON, 1980. Moisture Stres's in Navy Be ans. Effect of Withholding. Irrigation at Different Fenolo gical Stages on Growth and Yied. Irrigation Science. Berlin, $\underline{2}$ (1): 49-58. Apud: Soils and Fertilizers, 45 (3): 293, 1982 .

HANSEN, V.E., 1953. Water Storage Efficiency. Journal Agricul. tural Engineering. 34 (2) : 825-833.

HANSEN. V.E., 1960. New Concepts in Irrigation Efficiency Transactions of the ASAE.. St. Joseph, $\underline{3}(1): 55-64$.

HORNER, G.M. e M. MOJTEREDI, 1970. Yield of grain legumes as affected by Irrigation and Fertilizer Regimes. Agronomy Journal. Madison, 62: 449-450.

INFORZATO, R. e S. MIYASAKA, 1963. Sistema Radicular do Feijoeiro em Dois Tipos de Solo do Estado de São Paulo. Bragantia. Campinas, 22: 477-481.

KATTAN, A.A. e J.W. FLEMING, 1956. Effect of Irrigation at Specific Stages of Development on Yield, Quality, Growth and Composition of Snap Beans. Proceeding of the American Society for Horticultural Science. Geneva, 68: 329-392. 
KEMP, G.A.; K.K. KROGMAN e E.H. HOBBS, 1974. Effect of Sprin, kler Irrigation and Cooling on Yield and Quality to Snap Be an. Canadian Journal of Plant Science. Ottawa, 54: 521-528.

KOSTIAKOV, A.N., 1972: On the Dynamics of the Coefficient of Water Percolation in Soils and on the Necessity for Studying i.t from a Dynamic Point of View for Purposes of Ameleo: ration. Trans. Com. Intern. Society Soil Science Russian. 6 th, Part A, p. 17-21.

KRAMER, P.J., 1959. The Role of Water in the Physiology of Plants. Advances in Agronomy, New York, 11:51-70.

KRAMER, P.J., 1963. Water Stress and Plant Growth. Agronomy Journa1, Madison, 55 (1): 31-35.

KRETCHMER, P.J.; D.R. LAING e S. ZULVAGA, 1980. Uso de1 Termó metro Infrarrogo para la Selección por Tolerancia a Sequia. en Phaseolus vulgaris L. Cali (Colômbia), CIAT. 10p.

KUENEMANN, E.A.; D.A. WALLACE e P.M. LUDFORD, 1979. Photosyn thetic Measurements of Field Growth Dry Beans and Their Relations to Selection for Yield. Joumal of American Society for Horticultural Science. Geneve, 104(4): 480-482. 
LAWN, R.J., 1982a. Response of Four Grain Legumes to Water Stress in South-eastern Queesland. I. Physiological Respon se Macanisms. Australian Journal of Agricultural Research. Melbourne, Austrålia, 33: 481-496.

LAWN, R.J., 1982b. Response of Four Grain Legumes to Water Stress in South-eastern Queesland. II. Plant Growth and. Soil Water Extraction Patterns. Australian Journal of Agricul-: tural Research. Melbourne, Austrália, 33: 497-509.

LAWN, R.J., 1982c. Response of Four Grain Legumes to Water Stress in South-eastern Queesland III. Dry Matter Production, Yield and Water Use Efficiency. Australian Journal of Agricultural Research. Melbourne, Austrália, 33: 511-521.

LINDERMAN, C.L.; E.C. STEGMAN, 1971, Seadonal Variation of Hydraulic Parametres and Their Influence Upon Surface. Irrigation Application Efficiency. Transattion of ASAE. St. Joseph, 14 (5): 914-918.

MACK, H.J. e A.R. BONANNO, 1981. Water Stress Reduces Bush Beans and Sweet Corn Yields. Oregon Vegetable Digest. 30 (4) : 1-2. 
MAGALHAES, A.A. e A.A. MILLAR, 1978. Efeito do Déficit de Agua no Periodo Reprodutivo sobre a Produção do Feijão. Pes quisa Agropecuāria Brasileîra. Brasilia, 13 (2): 55-60.

MAGALHAES, A.A.; A.A. MILLAR e E.N. CHOUDHURY, 1979. Efeito do Déficit Fenológico de Ãgua sobre a Produção do Feijão. Turrialba, Turrialba, $\underline{29}$ (4): :269-273.

MAURER, A.R.; D.P. ORMROD e N.J. SCOTT, 1969. Effect of Five Soil Water Regimes on Growth and Composition of Snap Beans.. Canadian Journal of Plant Science. Ottawa, 49(3): 271-278.

MILLAR, A.A. e W.R. GARDNER, 1972. Effect of the Soil. Water Potentital on the Dry Matter Production of Snap. Beans. Agro. nomy Journal. Madison, : 64 (5) : 559-562, set.-out.

MILLAR, A.A. e E.N. CHOUDHURY; 1980. A Model to Define Operation Irrigation Frequency for Maximum Yield of Crop. Tur rialba. Turrialba, $30(4): 391-398$.

MIRANDA, 0. e C. BELMAR, 1977. Déficit Hídrico y Frequência de Riego en Frijol (Phaseolus vulgaris, L.) Agricultura Técnica. Chile, 37: 111-117. 
MUIRHEAD, D.A. e R.J.G. WHITE, 1981. The Influence of Soil'Wa ter Potential on the Flowering Pattern, Pod Set and Yield of Snap Beans (Phaseolus vulgaris L.). Irrigation Science, New York, $\underline{3}: 45-56$

NETTLES; F.V., 1948. Two Years Results of the Effect of Several Irrigation Treatments on the Yield of Cabbage and Snap Beans. Proceedings of the American Society Horticultural. Science, Geneva, 51: 463-467.

PAES CAMARGO, A.; H.S. PINTO; M.J. PEDRO Jr.; R.R. ALFONSI e A.A. ORTOLANI, 1974. Clima do Estado de São Paulo. In: SAEESP: Inst. Agronômico. Zoneamento Agrícola do Estado. de São Paulo. São Paulo, vol. 1.

RADLEY, L e A. PANOYA, 1970. Furrow Irrigation with Decreasing Inflow Rate. Journal Irrigation and Drainage Division. ASCE. Ann Arbor, 96(4): 451-460.

RAGGI, L.A.; S. BERNARDO e J.D. GALVAO, 1972. Efeito do Turno de Rega em Três Fases do Ciclo do Feijoeiro. Seiva. Viçosa, 32 $(76): 35-42$.

REICHARDT, K.; P.L. LIBARDI e J.M. SANTOS, 1974. An Analisis. of Soil Water Movement in the Field. II. Water Balance in a Snap Bean Crop. Piracicaba, CENA/ESALQ. 19p. (Boletin Cientifico, $\mathrm{BC}-022$ ). 
RESENDE, M., 1979. Effects of High and Norma1: Frequency Deficit Irrigation on Crop Development and Yield of Kidney Bean (Phaseolus vulgaris,L.). Davi.s University of California. Apud: Dissertation Abstracts International." Ann Arbor, 40 (10): 4595B, 1980 .

RICHARDS, L.A., 1947. Pressure Membrane Apparatus, Construction and Use. Agricultural Engineering. St. Joseph, 28: 451-454.

RITCHIE, J.T., 1981. Water Dynamics in the Soil - Plant - Atmosphere System. Plant and Soil The Hague, 58: 81-96.

ROBINS, J.S. e C.E. DOMINGOS, 1956. Moisture Déficits in Relation to the Growth and Development of Dry Beans. Agronomy. Journal. Madison, 48: 67-7.0.

SALTER, P.J. e J.C. GOODE, 1967. Crop Responses to Water at Different Stage of Growth. Bucks, Commonwealth Agricultural Bureaux. p. 52-57 (Rewew, 2).

SAWAZAKI, H.E. e J.P.F. TEIXEIRA, 1981. Estresse de Agua no Crescimento, Produtividade e Acúmulo de Prolina em Feijão. Bragantia. Campinas, 40:157-166. 
SIlVEIRA, P.M. da; J.R. FONSECA e C.M. GUIMARAES, 1981. Consu mo de Agua pelo Feijão de $3^{\text {a }}$ Epoca Irrigado por Aspersão. Goiânia, Centro Nacional de Pesquisa de Arroz e Feijão, 15p. (Comunicado Técnico 9).

SLATYER, R.0. 1969. Physiological Significance of Internal Wa ter Relations to Crop Yields. In: EASTIN, J.D. ed. et alii. Physiological Aspects of Crop Yield. Madison, Amer $\underline{\underline{i}}$ can Society of Agronomy, Crop Science. Society of America. $396 p$.

SOUZA, S.A., 1977. Manejo del Agua de Riego Bajo Diferentes. 'Métodos de Labranza em Maiz (Zea mays L.). Chapingo, Es-. cuela Nacional de Agricultura, 232p. (Tese de Mestrado).

STANSEL, J.R. e D.A. SMITTLE, 1980. Effects of Irrigation Regimes on Yield and Water Use of Snap Bean (Phaseolus vulgaris, L.). Journal American Society for Horticultural Scien ce. Geneva, 105: 869-87.3.

STOCKER, R. 1974. Effect on Dwarf Beans of Water Stress at Different Phases of Growth. New Zeland Journal of Experimental Agriculture. Wellington, $\underline{2}$ (1): 13-15. apud: Field Crops Abstracts, 1974, Aberytwyth, 27 (10): 526 . 
VAZIRI, C.M.; H.G. COLLINS e W.N. REYNOLDS, 1973. Furrow Irri gation Criteria for Hawaian Sugarcane. Journal Irrigation and Drainage Division, ASCE. Ann Arbor, $\underline{99}$ (1): 1-14.

VAZIRI, C.M. e I.P. WU., 1972. Volume Balance Analysis to Determine Water Infiltration and Efficiency in Hawaiian Sugár cane Furrows. Hawaiian Planters Record. Honolulu $\underline{58}$ (20): 283-292.

VIEIRA, J.L.T.M. e E.V: GATTí, 1983. Evolução da Produção do Feijão. Informações Econômicas, São Paulo, 13 (5) : 19-28, Maio.

WILLARDSON, L.S. e A.A. BISHOP., 1967. Analysis of Surface I $\underline{r}$ rigation Application Efficiency. Journal Irrigation and Drainage Division. ASCE, Ann Arbor, 93 (2): 21-36. 